\title{
Rybp is required for neural differentiation of mouse embryonic stem cells
}

\author{
Gergő Kovács \\ Ph.D. thesis
}

\author{
Supervisor: \\ Dr. Melinda K. Pirity \\ Theoretical Medicine Doctoral School \\ Universitiy of Szeged \\ Institute of Genetics
}

Biological Research Center of the Hungarian Academy of Sciences

Szeged

2016. 


\section{TABLE OF CONTENTS}

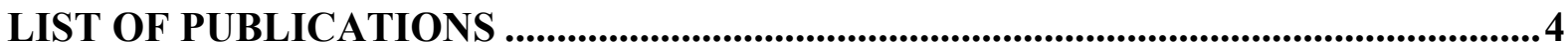

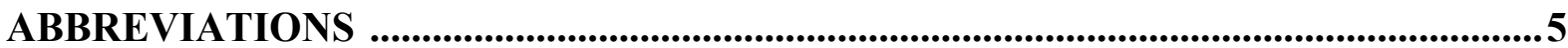

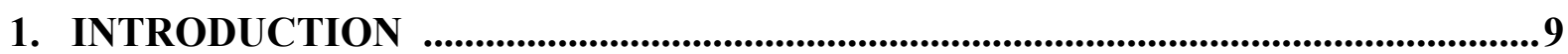

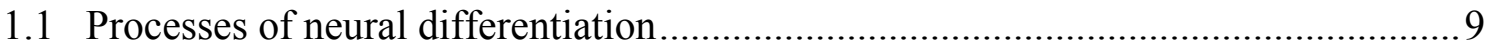

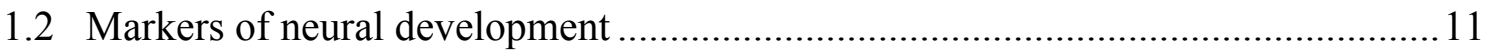

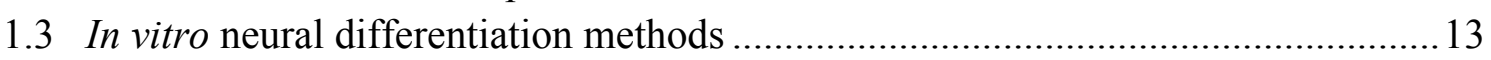

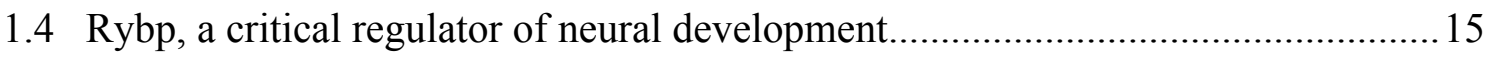

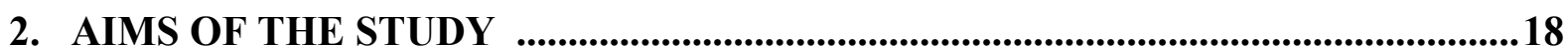

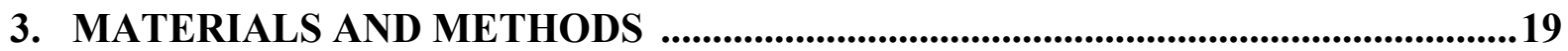

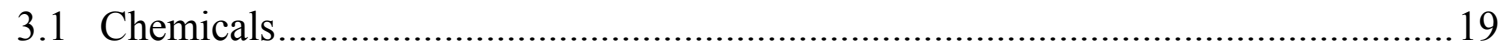

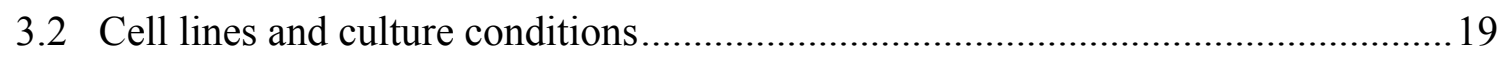

3.3 In vitro neural differentiation of mouse embryonic stem cells ................................20

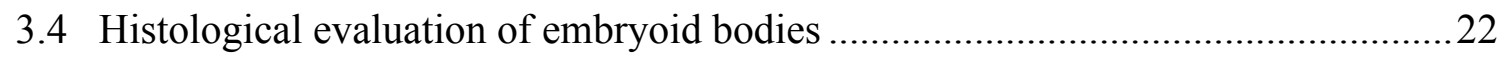

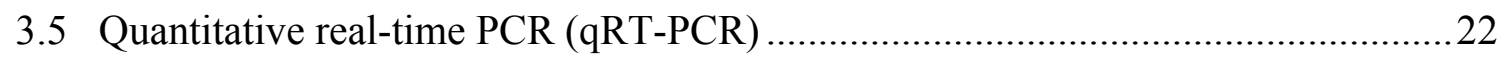

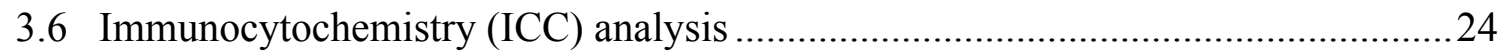

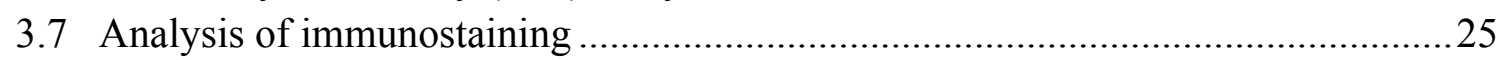

3.8 Global gene expression analysis by next-generation sequencing ..........................25

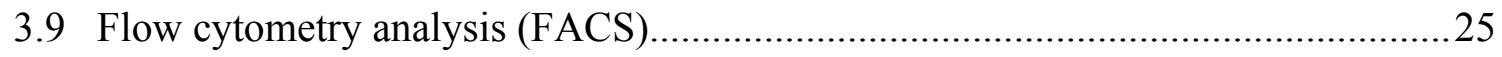

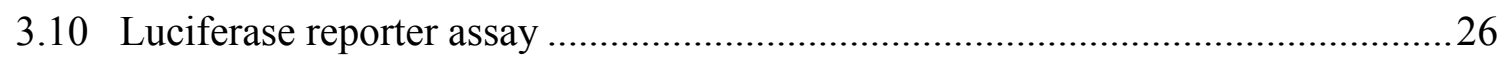

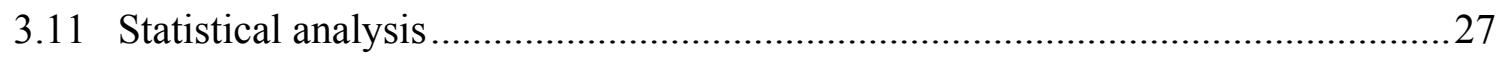

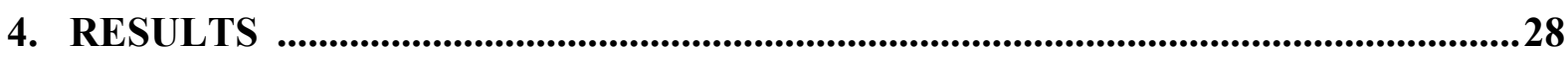

4.1 Morphology of $r y b p^{-/-}$neural derivatives indicated impairment in neural

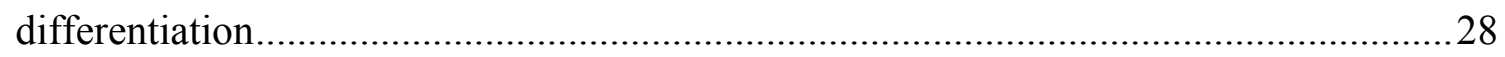

4.2 Attenuation of pluripotency markers was complete throughout in vitro neural

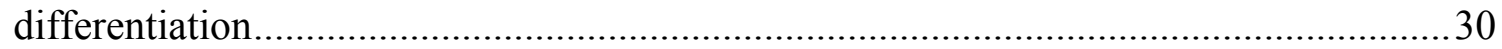

4.3 Lack of Rybp had minor influence on the expression of key PRC members ........... 31

4.4 Major germ layer formation was not impaired in the rybp null mutant embryoid

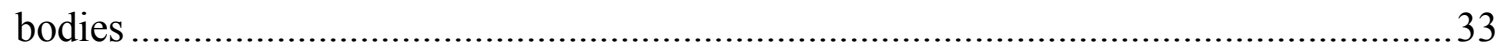

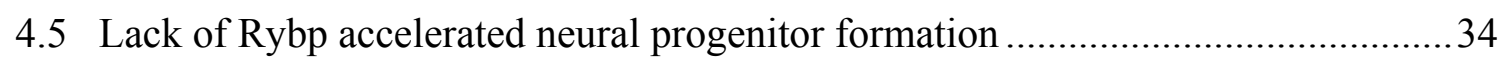

4.6 Absence of Rybp obscured terminal differentiation of neural lineages....................37

4.7 Dendrite and axon formation was impaired in the absence of Rybp ....................... 41

4.8 Plagll was not induced in the $r y b p^{-/-}$cells during in vitro neural differentiation .... 44

4.9 Lack of Rybp did not effect cell-cycle distribution but altered apoptosis ...............46

4.10 Rybp was able to activate Plagl1 through its promoter ...................................... 48

5. DISCUSSION ……….......................................................................................................50

5.1 Rybp is essential for the development of mature neural cell types...........................50

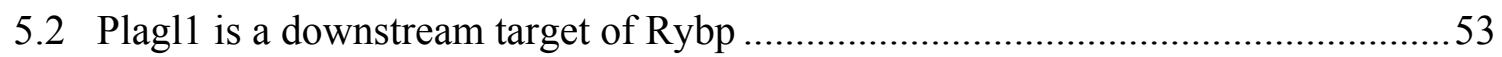


5.3 Rybp may exert its biological functions via biochemically heterogenic multimeric complexes

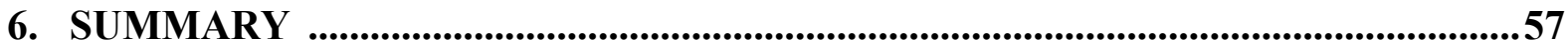

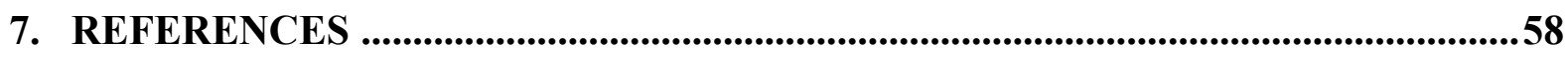

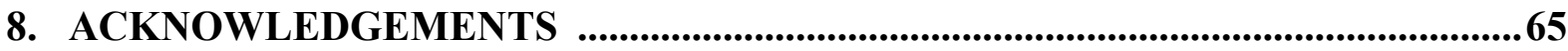

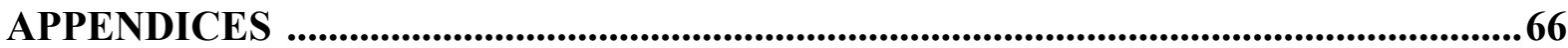




\section{LIST OF PUBLICATIONS}

This thesis is based on the following publications:

I. Kovács, G., Szabó, V., Pirity, M.K., Absence of Rybp Compromises Neural Differentiation of Embryonic Stem Cells. Stem Cells Int. (2015) doi: $10.1155 / 2016 / 4034620$

(2.813 impact factor)

II. Ujhelly, O., Szabo, V., Kovacs, G., Vajda, F., Mallok, S., Prorok, J., Acsai, K., Hegedus, Z., Krebs, S., Dinnyes, A., Pirity, M.K. Lack of Rybp in Mouse Embryonic Stem Cells Impairs Cardiac Differentiation. Stem Cells Dev. 24(18):2193-205. (2015) doi: $10.1089 / \mathrm{scd} .2014 .0569$

(3.727 impact factor)

Total impact factor: 6.54 


\section{ABBREVIATIONS}

aa

$\mathrm{AC}$

Bcl6

Bcor

bFGF - basic Fibroblast growth factor

Bmi1 - B lymphoma Mo-MLV insertion region 1 homolog

bp - base pair

Brg1 - Brahma-related gene 1

BrdU - 5-bromo-2'-deoxyuridine

BSA - bovine serum albumin

Cbx2 - Chromobox homolog 2

CNS - central nervous system

Ct - threshold cycle

CP - cortical plate

DAPI - 4',6-diamidino-2-phenylindole

Dedaf - Death effector domain-associated factor

DMEM - Dulbecco's modified eagle's medium

D-PBS - Dulbecco's phosphate-buffered saline

E2f - E2 promoter binding factor

EB - embryoid body

EDTA - Ethylenediaminetetraacetic acid

ES cells - embryonic stem cells 


\begin{tabular}{|c|c|}
\hline EYFP & - Enhanced yellow fluorescent protein \\
\hline Ezh1 & - Enhancer of zeste homolog 1 \\
\hline Ezh2 & - Enhancer of zeste homolog 2 \\
\hline FACS & - Flow cytometry analysis \\
\hline FBS & - fetal bovine serum \\
\hline Fbxl10 & - F-box and leucine-rich repeat protein 10 \\
\hline Fgf5 & - Fibroblast growth factor 5 \\
\hline Gfap & - Glial fibrillary acidic protein \\
\hline Gsc & - Goosecoid \\
\hline H\&E & - hematoxylin-eosin \\
\hline HBS & - Hepes buffered saline \\
\hline Hprt & - Hypoxanthine phosphoribosyltransferase 1 \\
\hline ICC & - Immunocytochemistry \\
\hline Ift57 & - Intraflagellar transport 57 \\
\hline IZ & - intermediate zone \\
\hline Jarid2 & - Jumonji, AT rich interactive domain 2 \\
\hline Jmj & - Jumonji \\
\hline Kdm2b & - Lysine (K)-specific demethylase $2 b$ \\
\hline LIF & - Leukemia inhibitory factor \\
\hline Lot1 & - Lost on transformation 1 \\
\hline Map2 & - Microtubule-associated protein 2 \\
\hline MapT & - Microtubule-associated protein tau \\
\hline MEF & - mouse embryonic fibroblast \\
\hline Mel18 & - DNA-binding protein Mel-18 \\
\hline
\end{tabular}




\begin{tabular}{|c|c|}
\hline MZ & - marginal zone \\
\hline $\mathbf{N}$ & - neuron \\
\hline Nanog & - Nanog homeobox \\
\hline ncPRC & - non-canonical Polycomb repressive complex \\
\hline NeuN & - Neuronal nuclei \\
\hline NeuroD1 & - Neurogenic differentiation 1 \\
\hline NSC & - neural stem cell \\
\hline NPC & - neural progenitor cell \\
\hline NTD & - neural tube defect \\
\hline OC & - oligodendrocyte \\
\hline Oct4 & - Octamer-binding protein 4 \\
\hline Olig2 & - Oligodendrocyte transcription factor 2 \\
\hline padj & - adjusted p-value \\
\hline Pax6 & - Paired box 6 \\
\hline PBS & - phosphate buffered saline \\
\hline PcG & - polycomb group \\
\hline Pcgf & - Polycomb group ring finger \\
\hline PI & - propidium-iodide \\
\hline PFA & - paraformaldehyde \\
\hline Plagl1 & - Pleiomorphic adenoma gene-like 1 \\
\hline Pou5f1 & - POU domain, class 5, transcription factor 1 \\
\hline PRC & - Polycomb repressive complex \\
\hline qRT-PCR & - quantitative real-time polymerase chain reacti \\
\hline
\end{tabular}




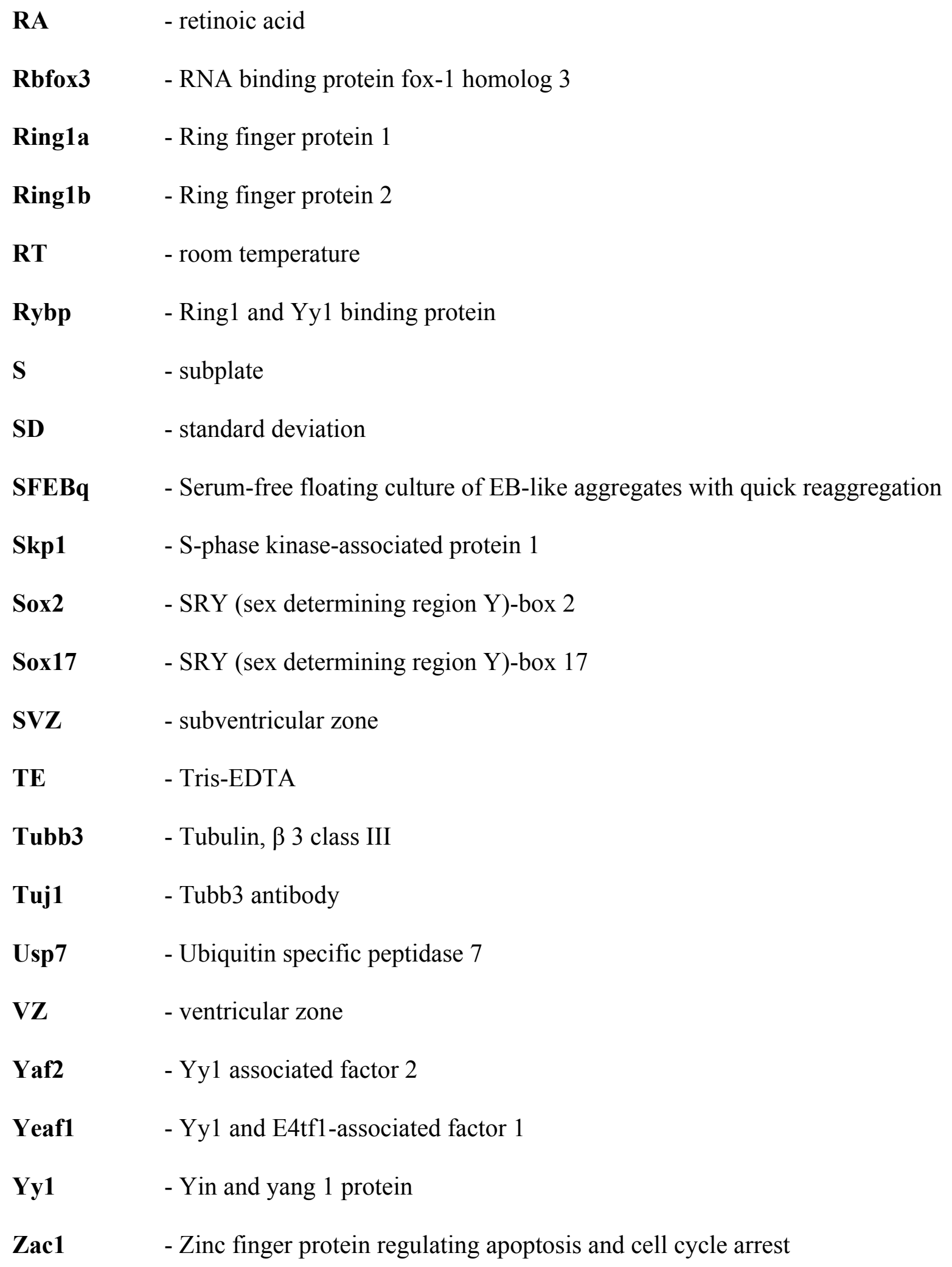




\section{INTRODUCTION}

During vertebrate embryonic development every specialized cell type of the embryo develops from pluripotent embryonic stem cells (ES cells). ES cells have some unique abilities: they can indefinitely divide and self-renew, when each new cell remains a pluripotent stem cell or they can differentiate into a cell type with a specialized function, such as muscle or nerve cells. Remarkably they have the ability to contribute to the germline when introduced back to the early stage embryo. During embryonic development, specific regulators control the balance between differentiation and self-renewal.

Polycomb group (PcG) proteins are epigenetic regulators of transcription with essential roles in maintaining ES identity and initiating cell lineage commitment throughout the process of differentiation. This study shows that the PcG protein Rybp (Ringl and Yyl binding protein, also known as Dedaf (Death effector domain-associated factor) and Yeaf1 (Yyl and E4tf1associated factor 1)) has essential role in neural lineage commitment of pluripotent ES cells.

\subsection{Processes of neural differentiation}

The mammalian nervous system has an ectodermal origin. In the early phase of neural development embryonic ectoderm forms the neuroectoderm where the multipotent neural stem cells (NSCs) are developing (Bergquist, 1964). The NSCs can sequentially generate all neural cell types of the central nervous system (CNS) and the peripheral nervous system through asymmetric cell division, and they also have the capacity for self-renewal through symmetric cell division (Gage, 2000). The NSCs differentiate into two major types of neural progenitor cells (NPCs): neuronal progenitors and glial progenitors (also called radial glial stem cells), which can develop oligodendrocyte precursors (Figure 1). At this phase of neural development, the symmetric division of NSCs is dominant, which extends the NSC niche and provides the proper cell pool for the later processes.

In the late phase of neural induction, terminal differentiation is prevalent. The differentiation

of mature neuronal cell types begins when NPCs terminally exit from the cell-cycle (Lu et al., 
2000). At the late neural phase, terminally differentiated neurons, astrocytes and oligodendrocytes form from their corresponding progenitors through asymmetric division in a defined order. Throughout neurogenesis the cells gradually lose their proliferation ability (Figure 1).

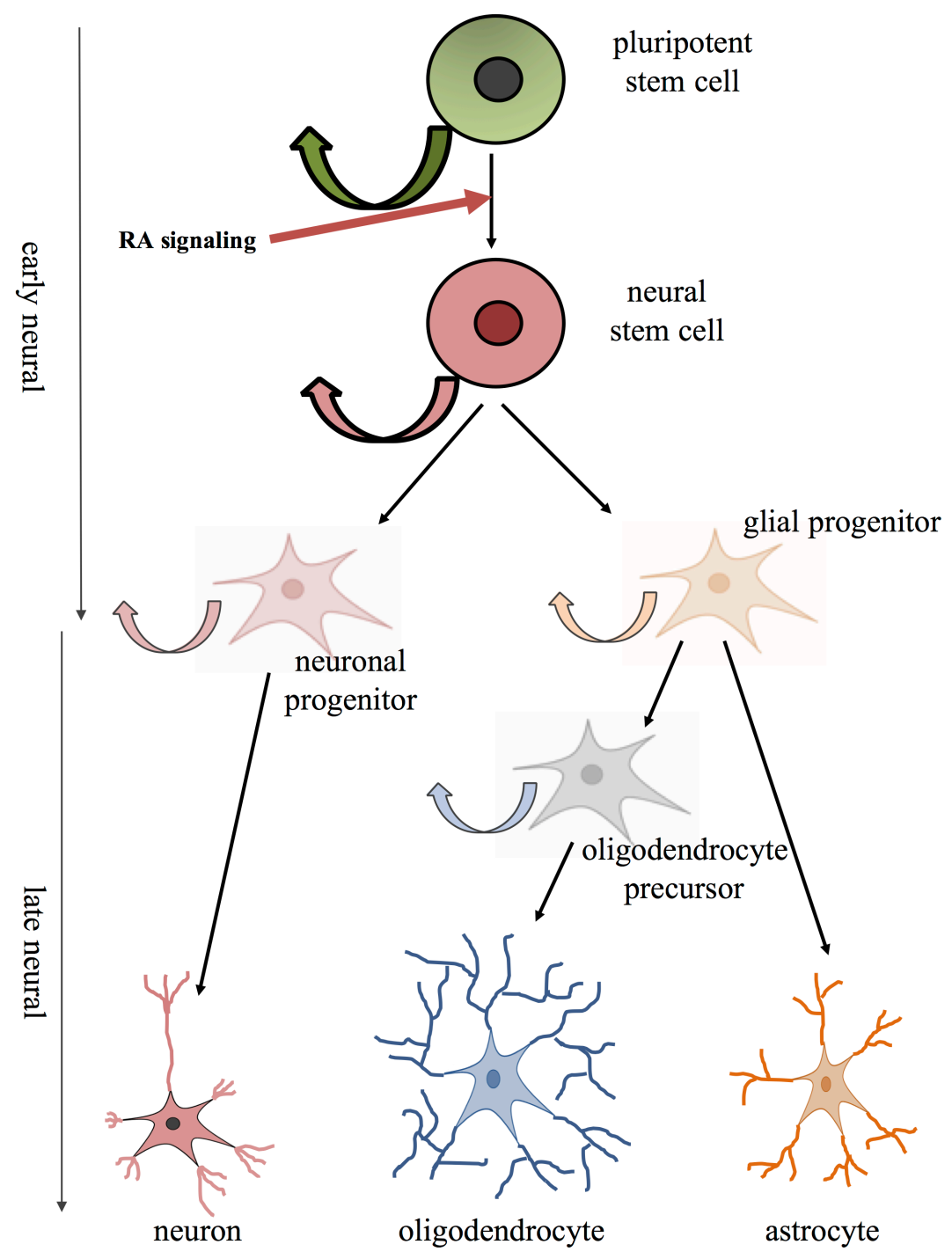

Figure 1 -Schematic figure of the neural differentiation of the ES cells

NSCs derive from pluripotent stem cells, then differentiate into neural progenitors and glial progenitors, which can develop oligodendrocyte precursors. These progenitors differentiate into mature neural cells in the late phase of neural development. Through differentiation the cells gradually lose their proliferation ability. RA: retinoic acid. 


\subsection{Markers of neural development}

The expression changes of transcription factors through neural development determine the emergence of different neural lineages. Expression of these factors is strictly governed both in space and time. Some factors play critical role in the early phase, other factors are important in the late phase of neural differentiation (Figure 2). Therefore, the expression changes of certain transcription factors indicate certain developmental stages and cell types through neural differentiation.

Through differentiation processes key pluripotency factors (e.g. Nanog (Nanog homeobox), Oct4 (Octamer-binding protein 4; also known as Pou5f1 (POU domain, class 5, transcription factor 1)), which are responsible for maintaining the undifferentiated pluripotent phase, are gradually downregulated. Sox2 (SRY (sex determining region Y)-box 2) is an exceptional pluripotency marker gene whose expression marks early neural processes as well by facilitating differentiation of stem cells to NSCs and NPCs, and maintains their self-renewal capacity (Graham et al., 2003; Thomson et al., 2011).

At the onset of neural differentiation Pax6 (Paired box 6) is upregulated, which induces the NSC formation (Gajović et al., 1997). Level of Pax6 is also elevated in the NPCs, but in maturing neural cells its level is decreased. Pax6 has an intense effect on controlling cell-cycle exit, which is a highly controlled process during neural differentiation (Farhy et al., 2013). Nestin is another marker of early neural processes and it is important for the development of NSCs and NPCs (Lendahl et al., 1990). This protein is important for the survival, the selfrenewal and the proliferation of NPCs, and the radial growth of the axons during embryonic development. NeuroD1 (Neurogenic differentiation 1) is also important for the early neural phase since it plays role in the transition from the NPC state to the maturing neural state (Boutin et al., 2010). 


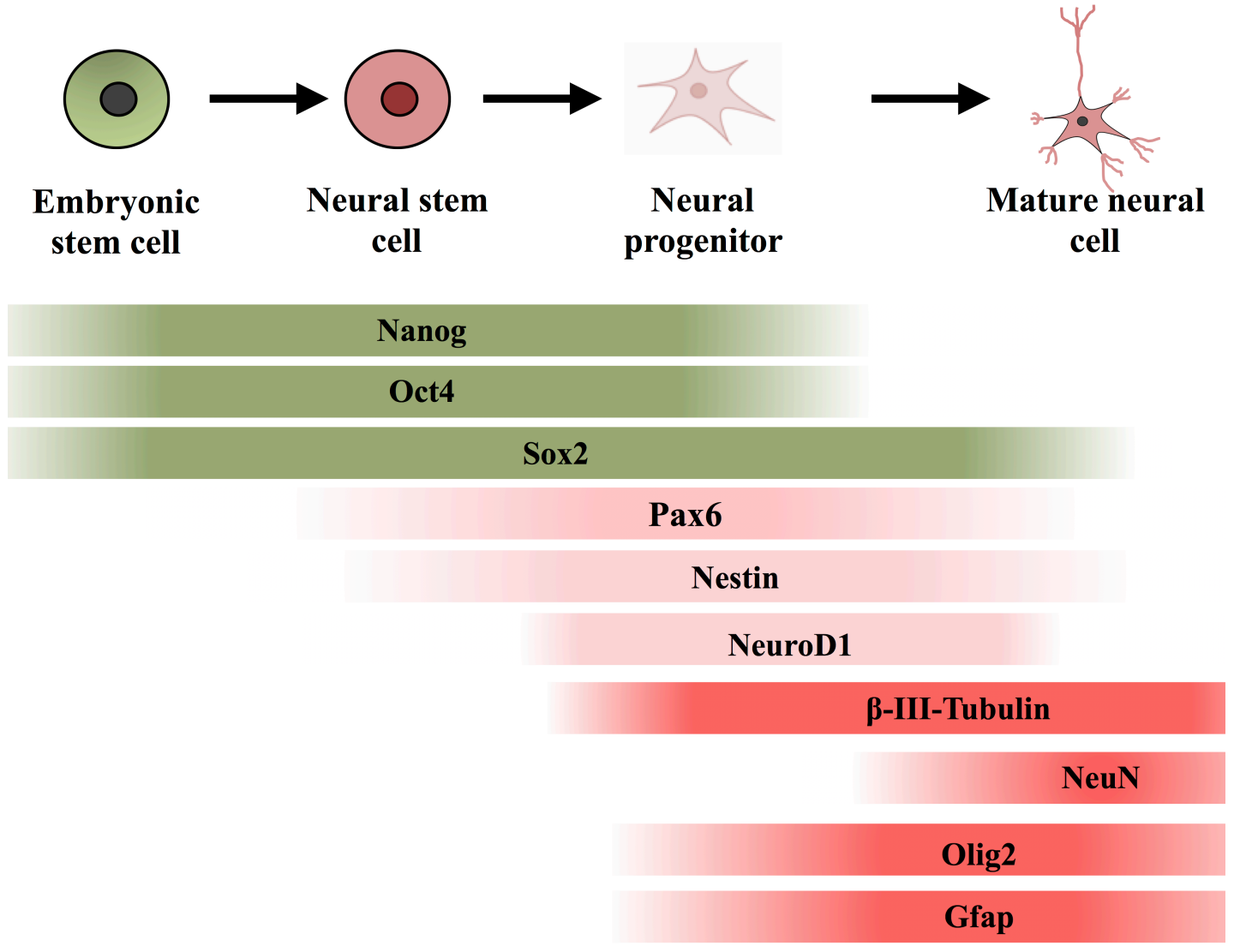

Figure 2 - Expression changes of pluripotency markers and neural markers through neural differentiation

Pluripotent factors are marked with green. Early and late neural differentiation markers are shown with pink and red colors, respectively.

Through the transition from early to late neural stage the developing NPCs start to express $\beta$ tubulin (also known as Tubb3 (Tubulin, beta 3 class III)). $\beta$-tubulin is important for the late phase of neural differentiation as it provides microtubule stability in the developing neurofilaments (Black et al., 1984) and its level remains high in mature neuronal cell types. $\beta$ tubulin is expressed exclusively in neurons (Fanarraga et al., 1999). Another mature neuronal marker is NeuN (Neuronal nuclei, also known as Rbfox3 (RNA binding protein fox-1 homolog 3)), which shows high expression in postmitotic neurons (Mullen et al., 1992). One of the important factors for the formation of oligodendrocytes is Olig2 (Oligodendrocyte transcription factor 2) (Mizuguchi et al., 2001; Takebayashi et al., 2002; Zhou et al., 2000), while in maturing astrocytes the Gfap (Glial fibrillary acidic protein) shows elevated expression (Bignami et al., 
1972; Eng et al., 1971), although it is also expressed in the radial glias.

Besides cell lineage markers some other genes are also critical for proper neural differentiation, such as Plag11 (Pleiomorphic adenoma gene-like 1; also known as Zac1 (Zinc finger protein regulating apoptosis and cell-cycle arrest) and Lot1 (Lost on transformation 1)). It was first described as a tumor suppressor (Abdollahi et al., 1997) and an important regulator of apoptosis and cell-cycle arrest since it has antiproliferative activity (Spengler et al., 1997). Plagl1 plays crucial role in neural development (Valente and Auladell, 2001) since plagl1 null mutant mice show defects in cortex development (e.g., reduced size of cerebellum, reduced number of mature neurons) (Chung et al., 2011), defects of neural tube closure and heart development as well (Yuasa et al., 2010). Plagl1 expressed in the neuroectoderm, in the progenitor cells of the telencephalic and cerebellar ventricular zones (VZs), the external granular cell layer, the retina and the developing heart (Valente et al., 2005).

\subsection{In vitro neural differentiation methods}

In vitro neural differentiation recapitulates the steps of in vivo neural development that occurs in the embryo. Therefore, the in vitro neural differentiation methods are excellent model systems of the in vivo development and allow the investigation of the spatiotemporal differentiation events at various developmental stages in the absence of environmental cues. Furthermore, all major neural cell types of the CNS can be generated and cultured under specific circumstances. These differentiated neural cells exhibit morphological and molecular properties of cultured primary neurons, and exhibit physiological functionality when transplanted into animals (Hemmer et al., 2014; Wernig et al., 2004).

Several in vitro differentiation methods have been developed to generate neural cells from ES cells (Figure 3) by co-culturing ES cells with stromal cells, culturing ES cells in monolayer, formation of embryoid bodies (EBs) and the formation of "cerebral organoids".

Neural differentiation can be facilitated in vitro by co-culturing ES cells on the surface of stromal cells in the absence of serum (Kawasaki et al., 2000). The stromal cells are special connective tissue cells, which produce inducing and inhibitory factors in co-culture system that promotes neural differentiation. 
ES cells in monolayer are also able to generate neural lineages (Tropepe et al., 2001). It has been described that ES cells cultured in serum-free medium at low cell density differentiate into "NSC-like" cell population. These "NSC-like" cultures can be further cultured on matrigel substrate in order to generate neurons, astrocytes, and oligodendrocytes.

An other method of in vitro neural differentiation is mediated by so called embryoid bodies (EBs). Formation of EBs can be generated in suspension cultures, in the presence of serum, when cells form three-dimensional cell aggregates. These aggregates mimic many hallmarks of early embryonic development such as forming all major germ layers: ecto-, endo- and mesoderm. Neuroectodermal formation can be facilitated by adding retinoic acid (RA) to the culture medium and the dosage of RA influences the properties of the developing neural cells (Bain et al., 1995). Differentiation of ES cells into neural lineages without RA treatment is also a routine procedure when the EBs are sequentially cultured in medium containing serum followed by serum-free medium (Okabe et al., 1996). After dissociation of EBs, the plated cells express neural markers and show typical neural physiological properties.

A recently developed method is the formation of SFEBq culture (Serum-free floating culture of EB-like aggregates with quick reaggregation), also known as cerebral organoids (Eiraku et al., 2008; Lancaster et al., 2013; Nasu et al., 2012). In these "organoids" the cells self-organize into structures which mimic many aspects of in vivo cortical development, including formation of cell layers which partially show the characteristics of discrete brain regions. 


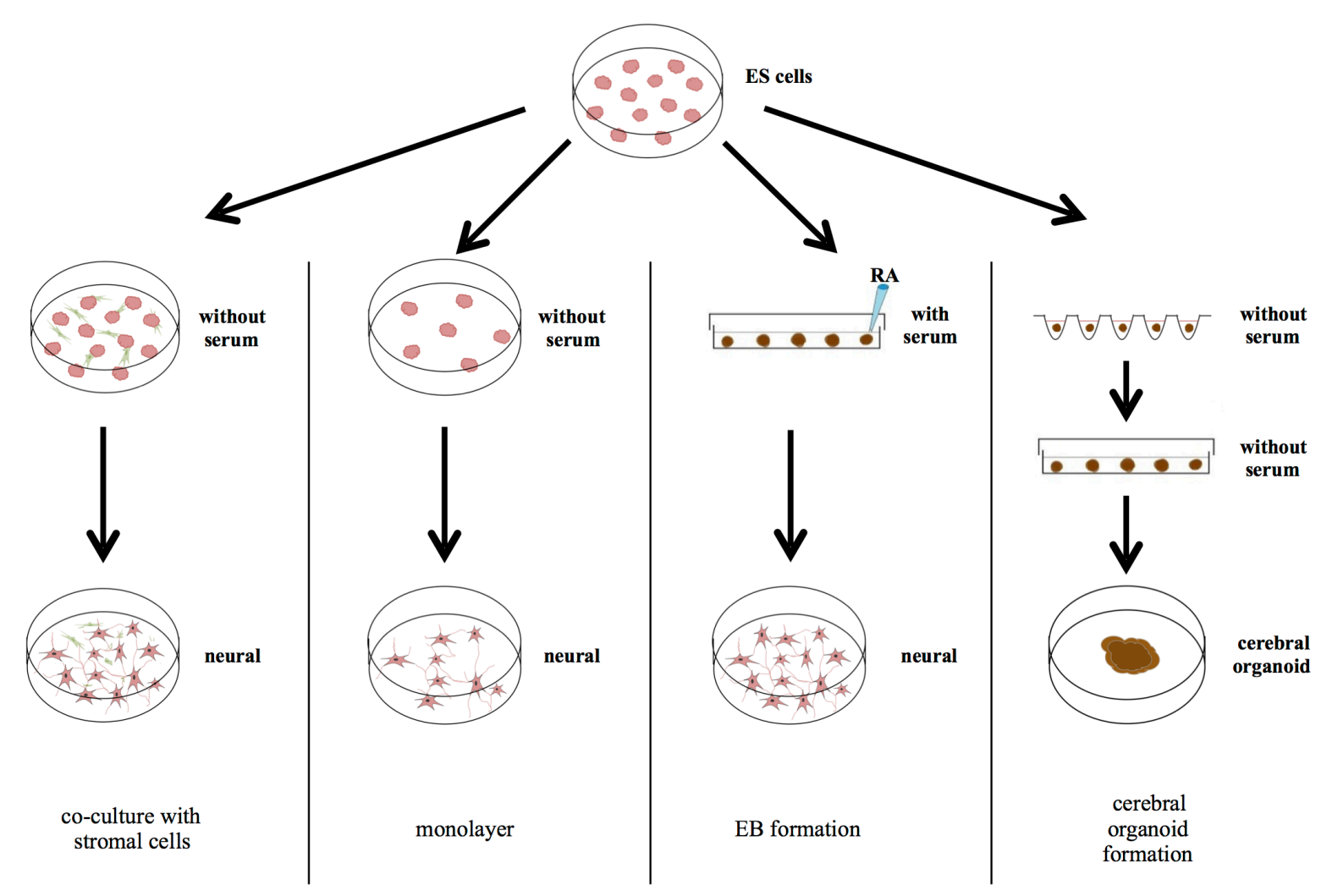

Figure 3 - Commonly used in vitro neural differentiation methods

Generation of neural lineages from ES cells in vitro is feasible by using differentiation of ES cells in co-culture with stromal cells, culturing ES cells in monolayer, via the formation of EBS and creating cerebral organoids. ES cells: embryonic stem cells, EB: embryoid body, RA: retinoic acid.

\subsection{Rybp, a critical regulator of neural development}

Rybp is an evolutionarily conserved transcription regulator. In mouse the $r y b p$ gene is located on the $6^{\text {th }}$ chromosome, the size of the gene is $58794 \mathrm{bp}$ and its protein product is 228 aa long. The human RYBP is $99 \%$ homologous to the mouse Rybp protein and the rybp gene is located on the $3^{\text {rd }}$ chromosome. The RYBP protein was isolated first as an interacting partner of the PcG protein Ring1a (also known as Ring1; Ring finger protein 1), Yy1 (Yin and yang 1 protein), Ring1b (also known as Ring2/Rnf2; Ring finger protein 2), and Cbx2 (Chromobox homolog 2; also known as M33) (García et al., 1999). Ring1a and Ring1b bind to the C-terminal region of 
Rybp, while Yy1 and Cbx2 interact with different domains of Rybp (García et al., 1999). The Rybp protein is partially homologous to Yaf2 (Yyl associated factor 2), an other Yy1 binding protein, and together they constitute a cofactor family (Sawa et al., 2002).

Rybp, together with Ringla and Ringlb, are members of non-canonical Polycomb repressive complex 1 (ncPRC1), also known as PRC1.1 (Chen and Dent, 2014; Farcas et al., 2012; He et al., 2013; Oliviero et al., 2015; Schwartz and Pirrotta, 2013; Turner and Bracken, 2013). PRC complexes have important role in cell lineage specification by maintaining ES cell pluripotency through repression of developmental regulators (Boyer et al., 2006; Simon and Kingston, 2013). The PRC1.1 complex encompassing Bcor (Bcl6 (B-cell lymphoma 6 protein) corepressor) as well, which plays important role in the differentiation of ES cells into ectoderm and mesoderm (Wamstad et al., 2008). In addition, Rybp interacts with chromatin modifiers (Brg1 (Brahmarelated gene 1)) (He et al., 2010) and pro-apoptotic factors (Pro-caspase 8, Pro-caspase 10, Ift57 (Intraflagellar transport 57; also known as Hippi),) (Stanton et al., 2007; Zheng et al., 2001). Several studies described downregulation of Rybp in tumors (Chen et al., 2009; Li et al., 2013; Taylor et al., 2010) and its forced expression helps to induce apoptosis and increased chemosensitivity of the tumor cells (Novak and Phillips, 2008; Voruganti et al., 2015; Wang et al., 2014; Zeng et al., 2015; Zhao et al., 2016).

In embryos Rybp is expressed in the developing CNS, especially in spinal cord, the pseudostratified neuroepithelial cells of the neural plate, some layers of the developing cortex including marginal zone (MZ), cortical plate (CP) and subventricular zone (SVZ), and the olfactory epithelium. Postnatally Rybp is expressed in outer cortical neurons of the forebrain and midbrain, and in the dentate gyrus of hippocampus (García et al., 1999; Pirity et al., 2005). Our laboratory previously showed that in a portion $(15-25 \%)$ of the $r y b p^{+/}$mice there were striking neural tube defects (NTDs). These mutant mice exhibited exencephaly, lack of cerebellum and failure of the closure of neural tube. (Pirity et al., 2005). One of the most striking effects was the disorganization of the neocortex in the rybp heterozygous mutant mice (Figure 4). The most affected parts in the cortex of $r y b p^{+/}$mice were the CP, the intermediate zone (IZ) and SVZ, where important steps of the corticogenesis take place, underlying the possible role of Rybp in this process. 

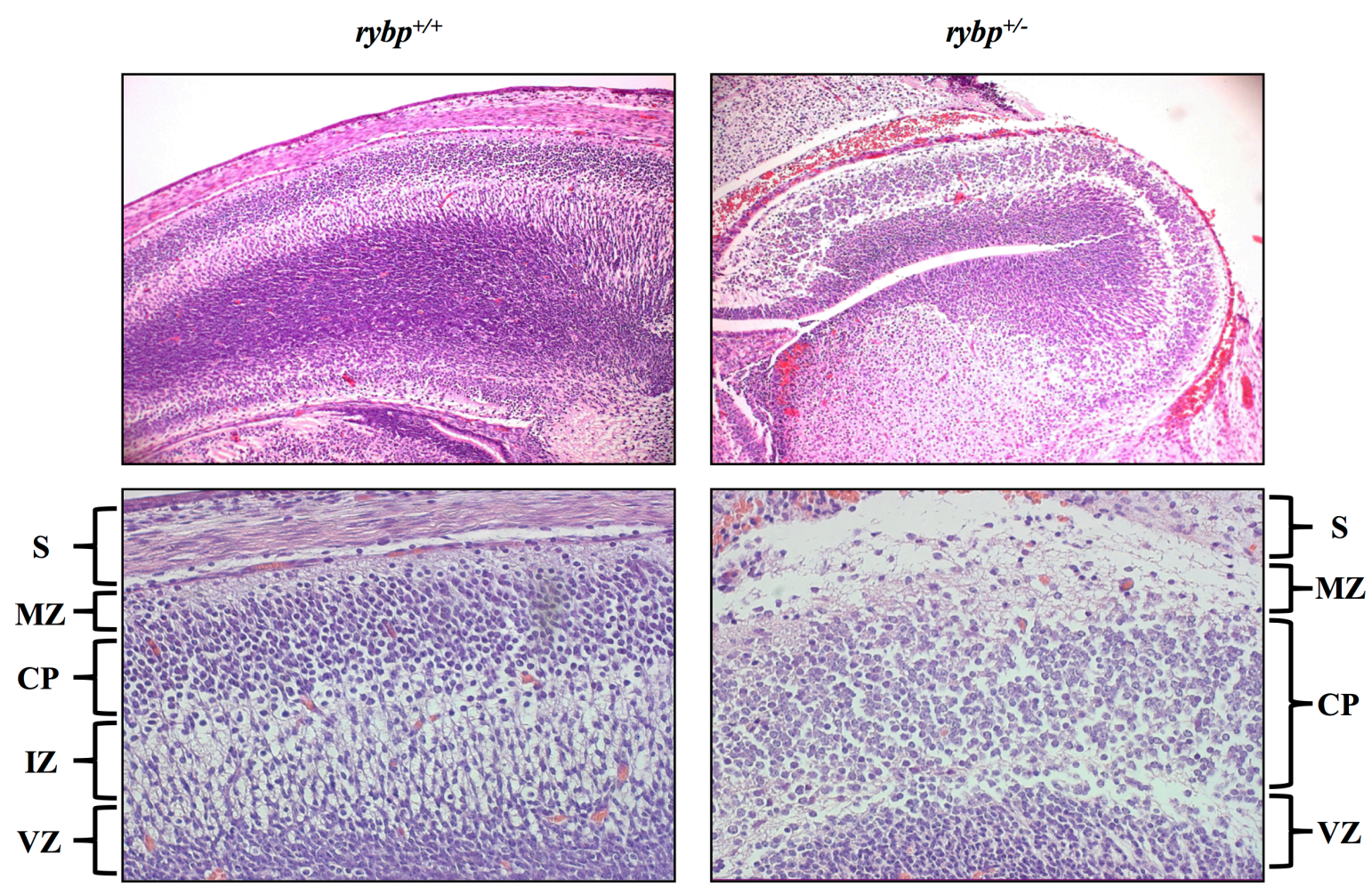

\section{Figure 4 - Sections of the cortex of wild type and rybp heterozygous mice}

The cortex of the rybp heterozygous mice $\left(r y b p^{+-}\right)$is disorganized compared to the cortex of the wild type mice. In the rybp ${ }^{+/}$cortex the CP is thicker and the IZ is absent. S: subplate, MZ: marginal zone, CP: cortical plate, IZ: intermediate zone, VZ: ventrical zone.

During my work I investigated underlying molecular events of the previously described CNS phenotype of the $r y b p$ heterozygous mice. We hypothesized that Rybp regulates genes, which are important for neural lineage commitment and in absence of Rybp the cells cannot undergo differentiation or has impaired differentiation ability. Since the early embryonic lethality of the rybp null mutant mice obscures the genetic analysis of neural lineage commitment in vivo, we utilized an in vitro ES cell based system to investigate the role of Rybp during neural differentiation. 


\section{AIMS OF THE STUDY}

The main goal of this thesis was to characterize the role of Rybp in neural lineage commitment.

The detailed aims of this study were:

- to examine whether the rybp null mutant mouse ES cells are capable to differentiate into all major neural lineages (neuron, oligodendrocyte, astrocyte).

- to characterize the properties of the progenitor cells derived from rybp null mutant mouse ES cells, especially with regard to their ability to balance self-renewal and differentiation during neural development.

- to determine which cell types have impaired differentiation capability as a result of Rybp absence.

- to find candidate downstream target genes of Rybp that have changed their expression depending on the presence or absence of Rybp during neural differentiation.

By aiming these, we hoped to gain more detailed information about the process of neural differentiation in vitro and to broaden our current understanding of congenital and neurological diseases. Besides this, in vitro generation of neurons from ES cells raises the prospect for potential future applications such as pharmacological testing systems to studying the pathogenesis of human diseases. 


\section{MATERIALS AND METHODS}

\subsection{Chemicals}

All chemicals were purchased from Sigma-Aldrich (St Louis, MO, USA), and culture media were purchased from Invitrogen Life Technologies (Carlsbad, CA, USA), unless stated otherwise.

\subsection{Cell lines and culture condition}

Mouse (129SV/Ola) R1 ES cells (Nagy et al., 1993) (hereafter mentioned as $r y b p^{+/+}$or wild type) and D11 ES cells (Pirity et al., 2005) (hereafter mentioned as $r y b p^{-/}$or null mutant) (Figure 5) were thawed on mitomycin $\mathrm{C}$ inactivated mouse embryonic fibroblast (MEF) layer and cultured on gelatin coated tissue culture plates as described (Magin et al., 1992).

The cells were maintained in ES medium: Dulbecco's modified eagle's medium (DMEM (1x) + GlutaMAXTM-I Dulbecco`s Modified Eagle Medium, Gibco, Cat. No 31966-021) contained 15\% (vol/vol) fetal bovine serum (Gemini Stasis Stem Cell Qualified FBS, West Sacramento, CA, USA, Cat. No 100-125), 0.1mM non essential amino acids (MEM Non Essential Amino Acids (100x), PAA, Cat. No M11-003), 0.1 mM $\beta$-mercaptoethanol (2-Mercaptoethanol, Gibco, Cat. No 31350-010), 1\% glutamine (L-Glutamine (200mM) Gibco, Cat. No 25030-081), 1\% sodium pyruvate (Sodium Pyruvate (100mM), Gibco, Cat. No 11360-070), $50 \mathrm{U} / \mathrm{ml}$ penicillin/streptomycin (Penicillin/Streptomycin (100x), PAA, Cat. No P11-010), and $1000 \mathrm{U} / \mathrm{ml}$ Leukemia inhibitory factor (LIF, ESGRO, Chemicon/Millipore, Billerica, MA, USA). The cells were passaged prior to reaching 70\% confluence (approximately every 1-2 days). ES cells were cultured on gelatin coated dishes for at least two passages prior to differentiation to deplete potentially present MEF cells from the ES cell culture. Cells were cultured in a humidified atmosphere containing $5 \% \mathrm{CO}_{2}$ at $37^{\circ} \mathrm{C}$. ES medium was changed daily.

COS7 cells were maintained in DMEM (DMEM with $4.5 \mathrm{~g} / 1$ glucose \& L-glutamine, Lonza, 
Cat. No BE12-604F) contained 10\% (vol/vol) FBS (Heat Inactivated FBS, Gibco, Cat. No 10500), 0.1mM non essential amino acids (MEM Non Essential Amino Acids (100x), PAA, Cat. No M11-003), 1\% sodium pyruvate (Sodium Pyruvate (100mM), Gibco, Cat. No 11360070) and $50 \mathrm{U} / \mathrm{ml}$ penicillin/streptomycin (Penicillin/Streptomycin (100x), PAA, Cat. No P11010)). The cells were passaged prior to reaching 95\% confluence (approximately every 3-4 days). Medium was changed every second day. Cells were cultured in a humidified atmosphere containing $5 \% \mathrm{CO}_{2}$ at $37^{\circ} \mathrm{C}$.

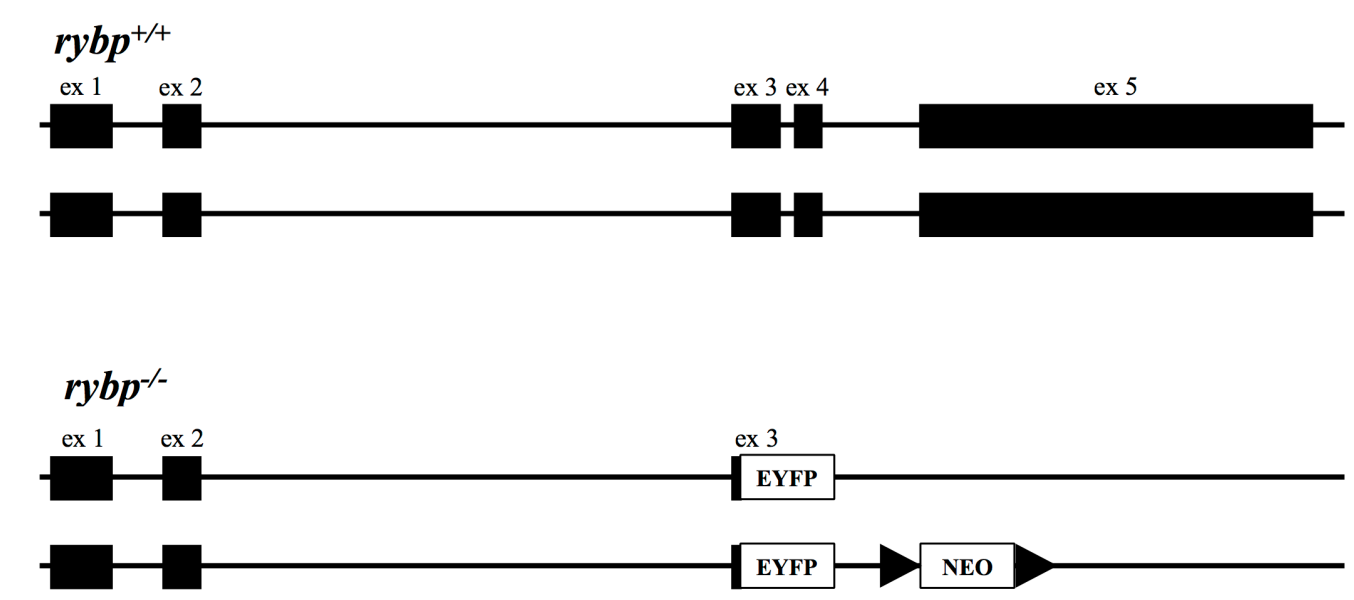

\section{Figure 5-ES cell lines used in this study}

In wild type cells $\left(r y b p^{+/+}\right)$, the rybp genomic locus contains 5 exons. In the rybp homozygous null cells $\left(r y \mathrm{bp}^{-/}\right)$the EYFP (Enhanced yellow fluorescent protein) following a floxed neomycin cassette is replacing exons 3, 4 and 5 creating a functional null mutant.

\subsection{In vitro neural differentiation of mouse embryonic stem cells}

ES cells were induced to differentiate into neuronal lineages as Bibel et al described, with some modifications (Bibel et al., 2004) (Figure 6). In brief, mouse ES cells were harvested as single cell suspension using $0.05 \%$ (wt/vol) trypsin (Trypsin-EDTA (1x) 0,05\% / 0,02\% in D-PBS, PAA, Cat. No L15-004), then seeded at a density of $4.5 \times 10^{5}$ cells $/ \mathrm{ml}$ in ES medium without LIF into $100 \mathrm{~mm}^{2}$ bacteriological dishes where cell attachment was prevented. ES cells were allowed to aggregate in suspension and formed embryoid bodies (EBs) for 8 days. Medium was 
changed on every second day during differentiation unless stated otherwise. On the $4^{\text {th }}$ day of EB formation $5 \mu \mathrm{M}$ all-trans RA (Retinoic acid, Sigma, Cat. No R2625-100MG) was added to the medium and EBs were cultured for a further 4 days in the presence of RA. Thereafter, 8day-old EBs were dissociated using trypsin and plated onto poly-L-ornithine (Poly-L-Ornithine 0.01\%, Sigma, Cat. No P4957) and laminin (Laminin from Engelbreth-Holm-Swarm murine sarcoma basement membrane, Sigma, Cat. No L2020-1MG) coated dishes at a density of $3 \times 10^{5}$ cells $/ \mathrm{cm}^{2}$ in DMEM/F-12 medium containing $3 \mathrm{mg} / \mathrm{ml}$ of D-(+)-glucose, $3 \mathrm{mg} / \mathrm{ml}$ AlbuMax I, $50 \mathrm{U} / \mathrm{ml}$ penicillin/streptomycin, 1\% (vol/vol) N-2 supplement (N-2 Supplement (100x), Gibco, Cat. No 17502-048), and $10 \mathrm{ng} / \mathrm{ml}$ recombinant human bFGF (Fibroblast Growth Factor Basic, human, Sigma, Cat. No F0291-25UG). The medium was changed 24 hours later. Two days after cells were plated, the medium was changed to DMEM/F12: Neuronal Base Medium (Neuronal Base Medium For Neuronal Cells, PAA, Cat. No U15- 023) (1:1)) containing $1 \mathrm{mM}$ GlutaMax, $3 \mathrm{mg} / \mathrm{ml}$ AlbuMax I, $50 \mathrm{U} / \mathrm{ml}$ penicillin/streptomycin, $0.5 \%$ (vol/vol) N-2 Supplement, and 1\% (vol/vol) B-27 supplement (B-27 Supplement (50x), Gibco, Cat. No 17504-044) and the cells were cultured for a further 4 days. The medium was changed 2 days later. The cells were harvested for further analyses at different time points of neural differentiation: days $0,3,7,10$ and 14 (labeled as d0, d3, d7, d10, d14). On d10 and d14 the differentiated cells were also stained with cresyl violet in order to visualize the cell colonies and morphology of the cells. The images of the ES cell cultures, EBs and stained neural culture were obtained using Olympus cellR microscope (Olympus Corporation, Japan).

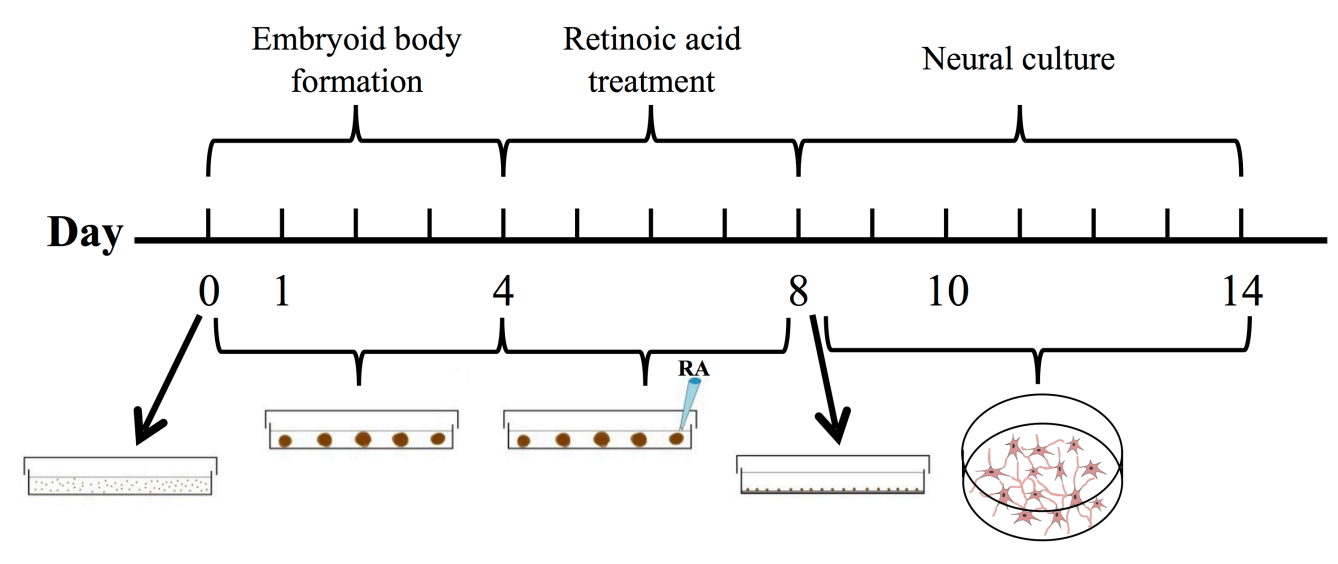

\section{Figure 6 - In vitro neural differentiation}

Schematic illustration of in vitro neural differentiation as described by Bibel et al. 


\subsection{Histological evaluation of embryoid bodies}

We assessed tissue organization and cellular morphology by histological evaluation of sectioned EBs. EB sectioning was performed by Hisztopatológia Kft. (Pécs, Hungary). The harvested EBs (d3, d7) fixed with 4\% paraformaldehyde (PFA) (Paraform-aldehyde, Sigma, Cat. No P6148), then stored in PBS. The PFA fixed EBs are first pelleted and embedded with HistoGel (Thermo Scientific, Cat. No HG-4000-012) in order to concentrate the EBs for subsequent embedding with paraffin. Liquefied HistoGel was added to the pellet, it was resuspended carefully in the HistoGel and let it to solidify by cooling at room temperature. The solidified HistoGel was placed in a tissue processor cassette, dehydrated with acetone, cleared it in xylene, infiltrated it with molten paraffin and let it to solidify. After the block was solidified it was sectioned with a Thermo Scientific HM325 Rotary Microtome. All cell blocks were cut on the microtome at 3-4 $\mu \mathrm{m}$. The sections mounted on microscope slides and stained with hematoxylin-eosin (H\&E) in order to enhance contrast between the tissues and cells. The sections were scanned with Panoramic DESK system. Using these techniques, various tissues can be commonly recognized such as neural rosette-like structures.

\subsection{Quantitative real-time PCR (qRT-PCR)}

For quantitation of mRNA levels during the in vitro differentiation quantitative real-time PCR (qRT-PCR) assays were performed. Total RNA was extracted from the harvested cells using Qiagen RNeasy Plus Mini Kit (Qiagen, Cat. No 74134 Hilden, Germany) according to the manufacturer's instructions. cDNA synthesis was achieved with the isolated RNA using Applied Biosystems High capacity cDNA Reverse Transcription Kit (Invitrogen Life Technologies, Cat. No 4368814 Carlsbad, CA, USA) according to the manufacturer's instructions.

qRT-PCR was performed in SYBR Green master mix (SYBR ${ }^{\circledR}$ Select Master Mix for CFX, Applied Biosystems, Cat. No 4472942) using Bioer LineGeneK Real-time PCR System (Bioer, 
China). Relative gene expression changes were quantified using the $\Delta \Delta \mathrm{Ct}$ method. The threshold cycle $(\mathrm{Ct})$ values for each gene were normalized to expression level of Hprt (Hypoxanthine phosphoribosyltransferase 1), as internal control. To calculate fold change, the values compared to undifferentiated samples $\left(\mathrm{d} 0, r y b p^{+/+}\right)$. The primers used in this study were listed in Table 1. Unigene and Mouse Genome Informatics (MGI) ID numbers of examined markers are listed at Appendix B, Table S1.

\begin{tabular}{|c|c|c|}
\hline Gene name & Forward primer sequence & Reverse primer sequence \\
\hline Ezh1 & 5'-AATATGGGAGCAAAGGCTCTGTATGTG-3' & 5'-CACGAAGTTTCTTCCACTCTTCATTGAG-3' \\
\hline Ezh2 & 5'-TTACTGCTGGCACCGTCTGATGTG-3' & 5'-TGTCTGCTTCATCCTGAGAAATAATCTCC-3' \\
\hline Fgf5 & 5'-CAAAGTCAATGGCTCCCACGAAG-3' & 5'-CTACAATCCCCTGAGACACAGCAAATA-3' \\
\hline Gfap & 5'-AGATGAAACCAACCTGAGGC-3' & 5'-CCTCCAGCGATTCAACCTTT-3' \\
\hline Gsc & 5'-TCCAGGAGACGAAGTACCCAGACGT-3' & 5'-CTCGGCGGTTCTTAAACCAGACCT-3' \\
\hline Hprt & 5'-AGTCCCAGCGTCGTGATTAG-3' & 5'-GCAAGTCTTTCAGTCCTGTCC-3' \\
\hline Jmj & 5'-AGGCGGTAAATGGGCTTCTTGGTA-3' & 5'-AGCCTGGGCCTTTTCCTCGAC-3' \\
\hline Map2 & 5'-AAAGAGAACGGGATCAACGG-3' & 5'-TTGTGTTGGGCTTCCTTCTC-3' \\
\hline Nanog & 5'-CAAGGGTCTGCTACTGAGATGCTCTG-3' & 5'-TTTTGTTTGGGACTGGTAGAAGAATCAG-3' \\
\hline Nestin & 5'-AGTGCCCAGTTCTACTGGTGTCC-3' & 5'-CCTCTAAAATAGAGTGGTGAGGGTTGA-3' \\
\hline NeuN & 5'-AATACATTTCGAGCTGCACCA-3' & 5'-AACAAGCGTTTGCTCCAGT-3' \\
\hline NeuroD1 & 5'-CGAGTCATGAGTGCCCAGCTTA-3' & 5'-CCGGGAATAGTGAAACTGACGTG-3' \\
\hline Oct4 & 5'-AGCCGACAACAATGAGAACC-3' & 5'-TCTCCAGACTCCACCTCACA-3' \\
\hline Olig2 & 5'-CGCAGCGAGCACCTCAAATCTAA-3' & 5'-CCCAGGGATGATCTAAGCTCTCGAA-3' \\
\hline Pax6 & 5'-CTTGGGAAATCCGAGACAGA-3' & 5'-CTAGCCAGGTTGCGAAGAAC-3' \\
\hline Plagl1 & 5'-ATGGCTCCATTCCGCTGTC-3' & 5'-CTCAGCCTTCGAGCACTTGAA-3' \\
\hline Ring1a & 5'-TGCCTGCATAGGTTCTGCTC-3' & 5'-GACCGCTTGGATACCAGCTT-3' \\
\hline Ring $1 \mathrm{~b}$ & 5'-ACAATCAGCAGGCTCTCAGC-3' & 5'-CAGTGGGAGCTGTCACCATT-3' \\
\hline Rybp & 5'-TTAGGAACAGCGCCGAAG-3' & 5'-GCCACCAGCTGAGAATTGAT-3' \\
\hline Sox2 & 5'-GCAGTACAACTCCATGACCA-3' & 5'-TAGGACATGCTGTAGGTGGG-3' \\
\hline Sox 17 & 5'-GCCAAAGACGAACGCAAGCG-3' & 5'-TTCTCTGCCAAGGTCAACGCCT-3' \\
\hline Tau & 5'-ATGTCAGGTCGAAGATTGGC-3' & 5'-ATTATCTGCACCTTGCCACC-3' \\
\hline Tubb3 & 5'-TGAGGCCTCCTCTCACAAGT-3' & 5'-GGCCTGAATAGGTGTCCAAA-3' \\
\hline Yyl & 5'-TGCCCTCATAAAGGCTGCAC-3' & 5'-CTCTCAACGAACGCTTTGCC-3' \\
\hline
\end{tabular}

Table 1 - Primers used in $q R T-P C R$ reactions 


\subsection{Immunocytochemistry (ICC) analysis}

For immunofluorescence staining of the neural cell culture, the cells were plated onto coverslips, differentiated into neuronal lineages as described above and fixed with 4\% PFA for $20 \mathrm{~min}$ at room temperature (RT). After permeabilization in $0.2 \%$ Triton X-100 (Triton® X100, Sigma, Cat. No T8787-250ML) in PBS (D-PBS (1X) Dulbecco`s Phosphate Buffered Saline, Gibco, Cat. No 14190-094) for $20 \mathrm{~min}$ at RT, cells were blocked in 5\% bovine serum albumin (BSA) (Albumine from bovine serum, Sigma, Cat. No A7906) in PBS for $1 \mathrm{~h}$ at RT. Then sequentially incubated with the following primary antibody in $5 \% \mathrm{BSA}$ overnight at $4{ }^{\circ} \mathrm{C}$ : 2H3 (2H3, Hybridoma Bank, Iowa, USA, 1:1000), Gfap (Monoclonal Anti-Glial Fibrillary Acidic Protein Clone G-A-5, Sigma, Cat. No G3893, 1:400), Map2 (Anti-MAP2 antibody, Abcam, Cat. No ab32454, 1:1000), Nestin (Rat-401, Hybridoma Bank, Iowa, USA, 1:100), Pax6 (Pax6, Hybridoma Bank, Iowa, USA, 1:100), RC2 (RC2, Hybridoma Bank, Iowa, USA, 1:100), Tau (Tau (H-150), Santa Cruz Biotechnology, Cat. No sc-5587, 1:100), Tuj1 (Neuronal Class III $\beta$-Tubulin Polyclonal Antibody; Covance, Cat. No PRB-435P, 1:2500), and Zac1/Plag11 (Zac1 (M-300), Santa Cruz Biotechnology, Cat. No sc-22812, 1:1000). The cells were washed 5 times with PBS and incubated with fluorescent-labeled secondary antibody (Alexa Fluor 488 Goat-Anti-Mouse, Invitrogen, Cat. No A-10667; Alexa Fluor 647 DonkeyAnti-Mouse, Invitrogen, Cat. No A-31571; Alexa Fluor 647 Goat-Anti-Rabbit, Invitrogen, Cat. No A-21244) for $1 \mathrm{~h}$ at RT. Then the cells were washed 3 times with PBS. The cells were rinsed in 4',6-diamidino-2-phenylindole (DAPI; Vector Laboratories, Cat. No H-1200) for 20 min, washed 2 times with PBS and mounted in 50\% glycerol. The images were obtained using Olympus LSM confocal microscope (Olympus Corporation, Japan). 


\subsection{Analysis of immunostaining}

Semi-quantification of 2H3, Gfap, Map2, Nestin, Pax6, RC2, Tau, Tuj1 and Plag11 levels and the percentage of immunopositive cells was evaluated with ImageJ software (Rasband, W.S., National Institutes of Health, Bethesda, MD, USA).

\subsection{Global gene expression analysis by next-generation sequencing}

ES cells from a $6 \mathrm{~cm}$ culture dish were harvested by resuspension in 500mL TRIzol (TRIzol Reagent, Invitrogen, Cat. No 15596026), and total RNA was extracted with the TRIzol method according to the manufacturer's instructions. RNA was quality controlled by nanodrop and bioanalyzer. The extracted RNA was converted to cDNA and Illumina-compatible sequencing libraries using NuGEN Ovation and Encore NGS kits. Barcoded libraries were pooled and sequenced on an Illumina Genome Analyzer GAIIx in the single read mode with $80 \mathrm{nt}$ read length. Reads were mapped to the mouse genome using TopHat (Trapnell et al., 2009).

Differentially expressed genes between $r y b p^{+/+}$and $r y b p^{-/-}$ES cells were identified with DESeq and filtered for having a fold change $>1.5$ or $<-1.5$ and false discovery rate $<0.05$. In the case of increasing gene expression, the fold change value was calculated by the expression ratio of the rybp null mutant and the wild type samples; however, when the gene expression showed a decreasing tendency, the negative reciprocal of this quotient was used for the fold change calculation.

\subsection{Flow cytometry analysis (FACS)}

Cultured cells and EBs were incubated with $10 \mu \mathrm{M}$ BrdU (5-Bromo-2'-deoxyuridine, Sigma, Cat. No B9285-250MG) for 1h, then trypsinized into single cells and washed with PBS. Cells were fixed in $70 \%$ ice cold ethanol for $20 \mathrm{~min}$, denatured with $2 \mathrm{M} \mathrm{HCl}$ for $20 \mathrm{~min}$ and neutralized with $0.1 \mathrm{M}$ sodium borate $\left(\mathrm{Na}_{2} \mathrm{~B}_{4} \mathrm{O}_{7}\right.$, Molar Chemicals, Cat. No 07470-101-190, $\mathrm{pH} 8.5)$. Following washing with washing buffer (0.5\% BSA diluted in PBS), cells were stained 
with the primary monoclonal antibody anti-BrdU (BD Pharmingen, Cat. No 555627 1:100 diluted in dilution buffer contains $0.5 \%$ BSA and $0.5 \%$ Tween20 (Sigma Tween ${ }^{\circledR} 20$, Cat. No P5927-500ML) for 30 min at RT. Cells were washed with washing buffer, then incubated with Alexa Fluor ${ }^{\circledR}$ 647-labeled secondary antibody (Invitrogen, Cat. No A-31571, Donkey-AntiMouse, 1:1000) for $30 \mathrm{~min}$ at RT in dark. The cells were washed and resuspended in propidiumiodide (PI) (Propidium-iodide, Sigma, Cat. No P4170) $(10 \mu \mathrm{g} / \mathrm{ml}$ in PBS) then incubated for 30 min at RT in dark. Flow cytometry was performed using a Becton-Dickson FACS Calibur flow cytometer (Palo Alto, Temecula, CA, USA). FACS analysis was performed on different time points of neural differentiation $\mathrm{d} 0, \mathrm{~d} 3, \mathrm{~d} 7, \mathrm{~d} 10$ and $\mathrm{d} 14)$.

\subsection{Luciferase reporter assay}

COS7 cells were cotransfected with the following vectors: pGL3.Plagl1-Luc (a kind gift of Michael P. Czubryt), pcDNA3.1-HA:Rybp. We transfected these vectors in various concentrations (pGL3.Plagl1-Luc: $5 \mu \mathrm{g}$, pcDNA3.1-HA:Rybp: $1 \mu \mathrm{g}, 5 \mu \mathrm{g}, 25 \mu \mathrm{g}$ ) using $\mathrm{CaPO}_{4}$ transfection (Kingston et al., 2003; Wigler et al., 1979). $\mathrm{CaPO}_{4}$ transfection were performed as follows: 8 hours before transfection the cell culture medium was changed, the vectors were diluted in TE (Tris-EDTA (Trizma ${ }^{\circledR}$ base, Sigma, Cat. No T1503)) buffer, then we added 2.5 $\mathrm{M} \mathrm{CaCl}_{2}$ and 2x HBS (Hepes buffered saline (Hepes, Sigma, Cat. No H3375)) dropwise to the solution while we bubbled the mix providing oxygenation, finally we added this solution to the medium. 16 hours after transfection cell culture medium was changed. 48 hours after transfection the cells were washed with PBS and lysed with 1x Passive lysis buffer provided by reporter assay kit (Dual Luciferase Reporter Assay System, Promega, Cat. No E1500). $20 \mu \mathrm{g}$ of lysate from each point was mixed with $100 \mu 1$ Luciferase Assay Reagent II (provided by the kit) and the luciferase activity recorded immediately, according to the manufacturer's instructions. The luciferase activity was recorded with Perkin Elmer TopCount NXT Luminometer. All activities were measured in triplicate. 


\subsection{Statistical analysis}

All experiments were repeated three times. Experiments were evaluated with SPSS/PC+ version 17 program (SPSS, Chicago, IL) by using T-test type 3. The global gene expression analysis was evaluated by using Benjamini-Hochberg method (padj: adjusted p-value). Throughout the thesis, all data are expressed as mean \pm standard deviation (SD). Values of $p<$ 0.05 were accepted as significant $(* \mathrm{p}<0.05 ; * * \mathrm{p}<0.01 ; * * * \mathrm{p}<0.001)$. 


\section{RESULTS}

\subsection{Morphology of $r y b p^{-/}$neural derivatives indicated impairment in neural differentiation}

In order to model the in vivo neural phenotype of the $r y b p^{+/-}$mice we took advantage of the ES cell based in vitro neural differentiation system. Thus, we adopted the protocol by Bibel et al. in order to differentiate $r y b p^{+/+}$and $r y b p^{-/}$ES cells towards neural cell lineages (Bibel et al., 2004) (described in Materials and methods). In brief, suspension cultures were initiated using $4.5 \times 10^{5}$ cells $/ \mathrm{ml}$ seeding density and were kept in suspension for 8 days to form EBs. RA was added to the suspension cultures on the $4^{\text {th }}$ day (d4) and EBs were kept in RA supplemented medium until trypsinization on the $8^{\text {th }}$ day $(d 8)$, then seeded onto poly-L-ornithine/laminin coated surfaces in $3 \times 10^{5}$ cells $/ \mathrm{cm}^{2}$ seeding density and differentiated further for six days. Samples for analysis were taken at d0, d3, d7, d10, d14 and processed as required.
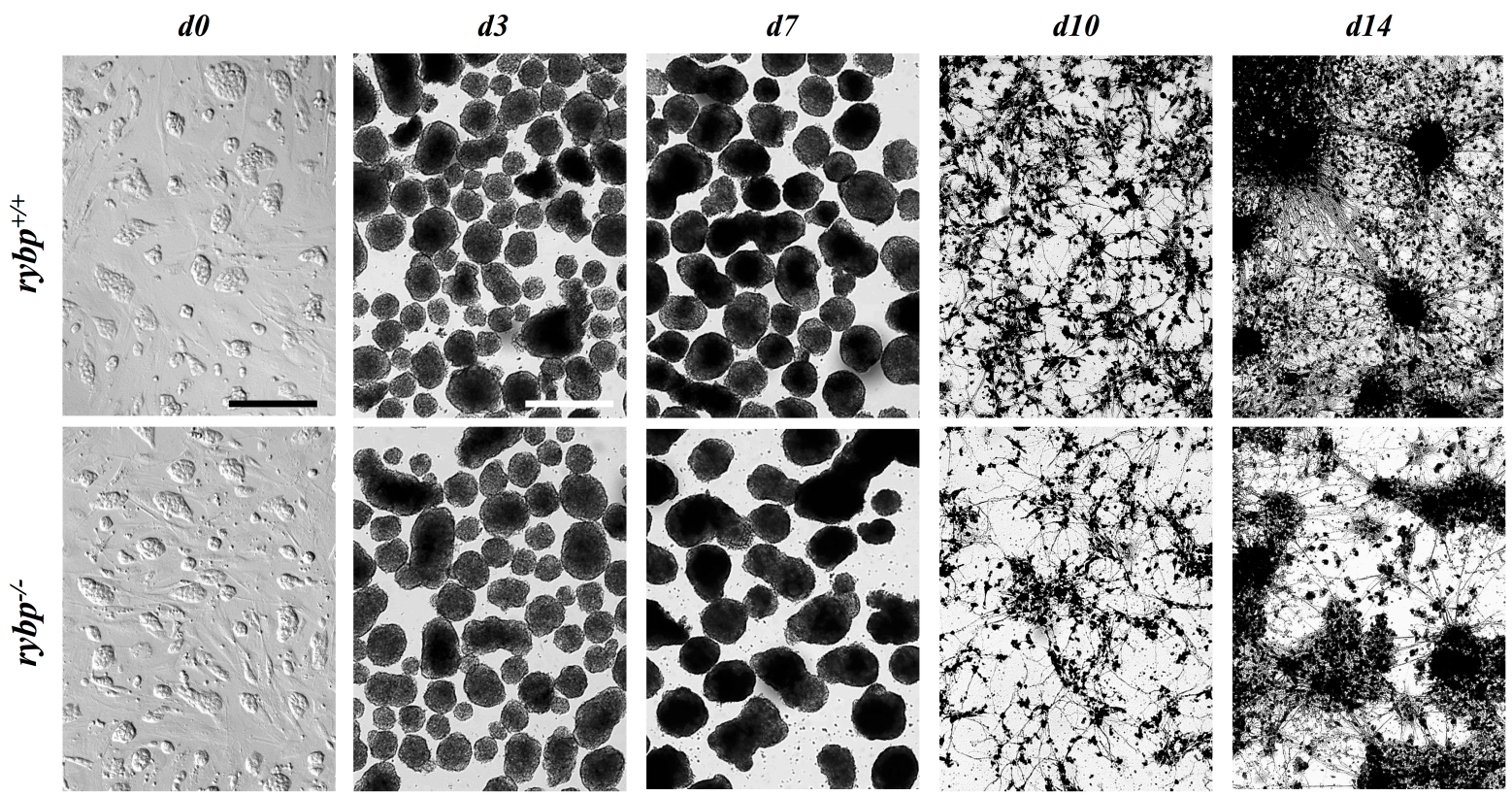

Figure 7 - Morphological changes of rybp ${ }^{+/+}$and rybp ${ }^{-/-}$cells through in vitro neural differentiation 
The rybp ${ }^{-/-}$ES cells displayed the same morphology in culture as the wild type (d0) and were able to form EBs (d3, d7). After plating (d10, d14) the rybp ${ }^{-/-}$cells grew less organized neural network than the wild type. Objectives: $4 x(d 3, d 7), 10 x(d 0, d 10, d 14)$. Scale bars: $200 \mu m$ (d0), $500 \mu m(d 3)$.

$R y b p^{-/}$ES cells displayed similar morphology in culture as the wild type cells (Figure $7 \mathrm{~d} 0$ ). EBs could be derived from both cell lines. As expected, EBs started to cavitate around day 2-3 (Figure $7 \mathrm{~d} 3$, dark core of EBs) and from day 4 endoderm and primitive ectoderm started to form as well. These suggested that $r y b p^{-/-}$cells were not compromised in their ability to proliferate and form EBs and they exhibited similar gross morphology (d3, d7) all over. However, H\&E stained sections of EBs pinpointed morphological differences between the two cell lines. On d3 EBs showed homogeneous morphology in both cell lines, and by d7 "neural rosette-like" structures formed, which constituted of neuroepithelial cells. The formation of "neural rosette-like" structures was accelerated in the $r y b p^{-/-}$EBs in comparison to the wild type. (Figure 8, black arrows).

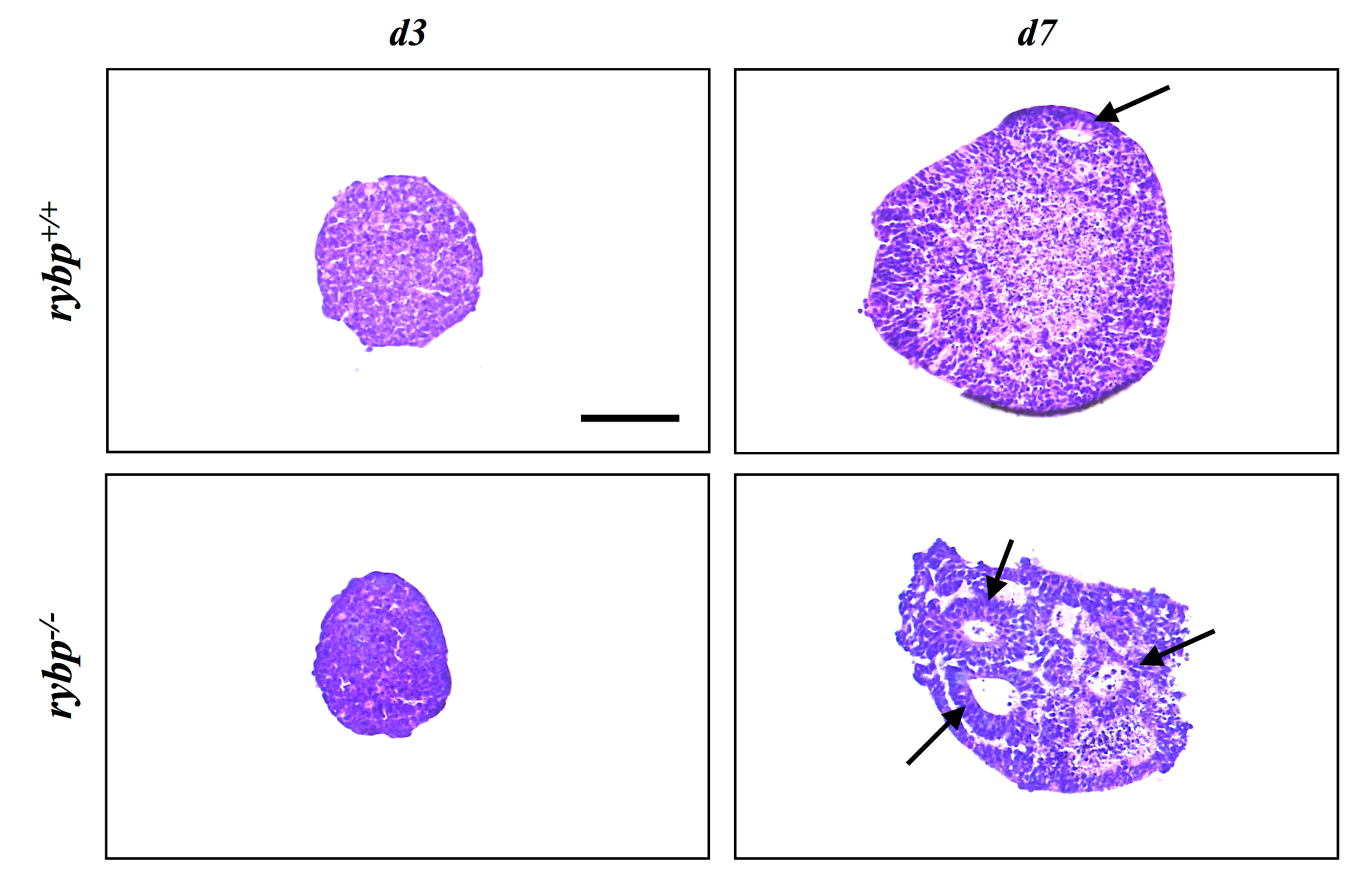

Figure $8-H \& E$ stained sections of rybp ${ }^{+/+}$and rybp ${ }^{-/}$EBs showed differences in germ layer formation

EBs at d3 showed homogeneous structure in both cell lines, while at d7 neural rosette-like 
structures (black arrows) formed inside of EBs in both cell lines. Neural rosette-like structure formation was accelerated in rybp null mutant compared to wild type. Magnification: 20x. Scale bar: $100 \mu \mathrm{m}$.

After dissociation of EBs and plating cells onto poly-L-ornithine and laminin coated surfaces (d8), the wild type cells exhibited typical neuronal morphology, the cells grew axon-like outgrowth, connected to each other and organized in a complex network consisting of heterogenous cell population. On the contrary, $r y b p^{-/}$derivatives grew less neurite processes and their organization into complex network was less extended in comparison to the wild type (Figure $7 \mathrm{~d} 10, \mathrm{~d} 14$ ). This difference was also observed at $\mathrm{d} 10$, but it was more prominent at d14. This phenotype was independent from the initial cell density (Figure $7 \mathrm{~d} 10$, d14; data not shown). The gross morphology of the cells suggested that neuronal differentiation was severely affected by the absence of Rybp.

\subsection{Attenuation of pluripotency markers was complete throughout in vitro neural differentiation}

To uncover underlying mRNA expression changes during in vitro neural differentiation we evaluated gene expression levels of $r y b p^{+/+}$and $r y b p^{-/}$cultures by qRT-PCR (Figure 9).

First we analyzed the expression of pluripotency markers in both cell lines at d0, d3, d7, d10 and d14. In undifferentiated stem cells, pluripotency factors work together with epigenetic regulators to maintain the pluripotent state and to suppress differentiation related genes. Incomplete silencing of the pluripotency genes during differentiation may cause impaired neural differentiation, therefore we had checked whether silencing of key pluripotency genes were proper in the absence of Rybp (Figure 9A). The analysis revealed that the expression of the examined pluripotency markers (Oct4, Nanog are shown on Figure 9BC) were progressively downregulated in both cell lines by differentiation and there were no significant changes in the kinetics of pluripotency gene expression between the $r y b p^{+/+}$and $r y b p^{-/}$cells. These results suggested that the silencing of pluripotency genes was properly executed in both cell lines.

The relative expression level of pluripotency marker Sox 2 was similar in both cell lines, with 
the exception on $\mathrm{d} 14$ when the level of Sox 2 is diminished in the rybp null mutant whilst it remained high in the wild type (Figure 9D). Although Sox 2 together with Oct4 and Nanog maintains pluripotency in stem cells, it is also important in the induction of neuroectoderm and maintains self-renewal of NPCs. This suggested that the differentiation ability of rybp null stem cells to NPCs or maintaining the characteristics of NPCs might be compromised. These results suggested that the silencing of key pluripotency genes exhibited similar kinetics with the exception of Sox2, which in the rybp null mutant drastically declined by $\mathrm{d} 14$.
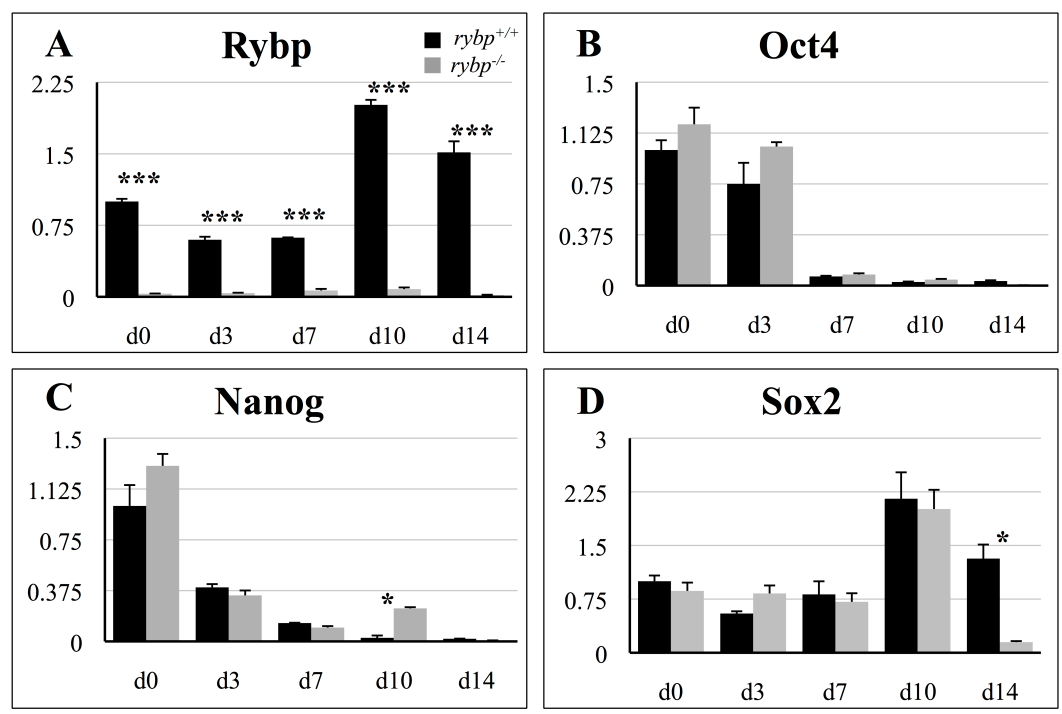

Figure 9 - In the lack of Rybp there was no change in silencing of key pluripotency markers (Oct4, Nanog, Sox2) during in vitro neural differentiation

Relative gene expression analysis of Rybp (A), Oct4 (B), Nanog $(\boldsymbol{C})$ and Sox2 (D) by qRT-PCR showed that silencing of pluripotent factors was properly executed in both cell lines. The expression of the indicated markers was normalized to Hprt expression, which used as an internal control. Means are standard deviation $\pm S D$. Values of $p<0.05$ were accepted as significant $(* p<0.05 ; * * p<0.01 ; * * * p<0.001)$. Statistical method: T test type 3.

\subsection{Lack of Rybp had minor influence on the expression of key PRC members}

Since PRCs play important role in maintaining pluripotency (Boyer et al., 2006; Simon and Kingston, 2013) and absence of Rybp may also effect PRC function, we wanted to check if the 
level of key PRC components has changed in the absence of Rybp during in vitro neural differentiation. We checked the relative expression changes of the PRC1 (Ring1a, Ring1b) and PRC2 (Ezh1 (Enhancer of zeste homolog 1), Ezh2 (Enhancer of zeste homolog 2)) members, using qRT-PCR analysis. We also checked the expression changes of Yy1, a known interactor of Rybp, and Jmj (Jumonji, also known as Jarid2 (Jumonji, AT rich interactive domain 2)), a known modulator of PRC2.

In our experiments during neural differentiation Ringla and Ring1b mRNAs showed elevated expression when neural differentiation occurs with a peak at $\mathrm{d} 10$. In the rybp null mutant cells the relative gene expression level of Ringla was half as much as in the wild type (Figure 10A), however, the expression of Ringlb and Yy1 was unaltered (Figure 10BC).

At undifferentiated state (d0) the mutant cells contained less amount of Ezh1 mRNA than the wild type. Consequently, during neural differentiation the level of Ezh1 and Ezh2 mRNA was gradually increasing until $\mathrm{d} 10$ in both cultures but in the mutant to a lesser extent. (Figure 10DE). The expression of Jmj was similar, independently from the presence of Rybp, except at undifferentiated stage (d0) (Figure 10F) when the mutant ES cells expressed less Jmj than the wild type ES cells. In summary: expression of PRC members was only slightly altered in the rybp null mutant.
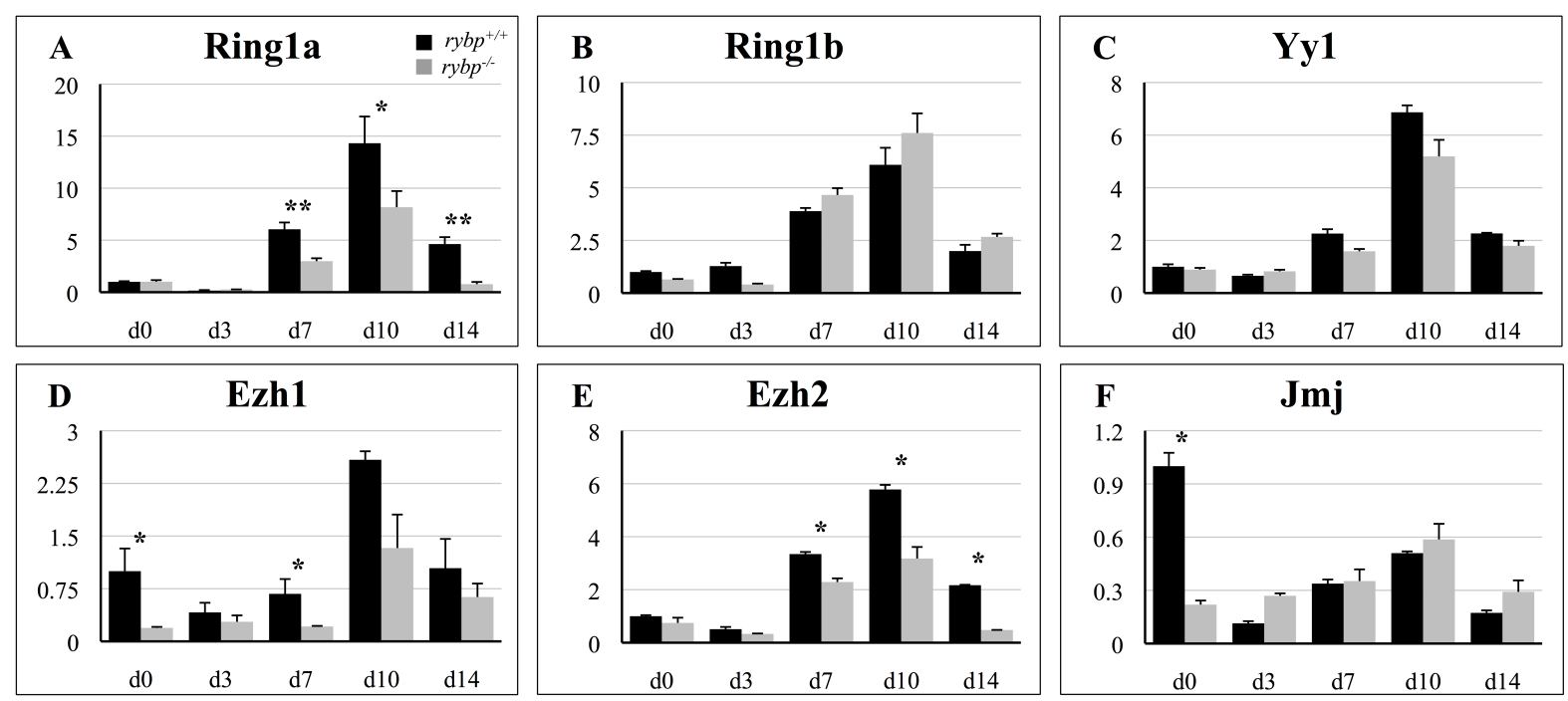

Figure 10 - Gene expression changes of PRC members (Ring1a (A), Ring1b (B), Yy1 (C), Ezh1 (D), Ezh2 (E), Jmj (F)) showed slight alteration 
Relative gene expression analysis of Ringla (A), Ringlb (B), Yyl (C), Ezh1 (D), Ezh2 (E), Jmj (F) by qRT-PCR showed that PRC function was probably not modified in lack of Rybp. The expression of the indicated markers was normalized to Hprt expression. Means are standard deviation $\pm S D$. Values of $p<0.05$ were accepted as significant $*^{*} p<0.05 ; * * p<0.01 ; * * *$ $p<0.001)$. Statistical method: T test type 3 .

\subsection{Major germ layer formation was not impaired in the rybp null mutant embryoid bodies}

To examine whether the impairment of neural development is a result of defective germ layer formation we investigated the formation of mesoderm, endoderm and ectoderm in the absence of Rybp.

During development Gsc (Goosecoid) is highly expressed during gastrulation when mesoderm is formed (Blum et al., 1992). In our experimental system expression of mesodermal marker Gsc was increased 3x at $\mathrm{d} 7$ in both cell lines (Figure 11A) and there was no difference in Gsc expression between the cell lines. This coincides with our previous observations when during in vitro cardiac differentiation both early mesodermal markers Gsc and Brachyury were expressed as expected but the $r y b p^{-/}$cells were not able to produce contractible cardiomyocytes (Ujhelly et al., 2015). This result shows that the lack of Rybp influences differentiation at later stages rather then mesoderm formation.

Next, we investigated proper endoderm formation by measuring the expression of Sox 17 (SRY (sex determining region Y)-box 17). Sox 17 is essential for endoderm differentiation since sox 17 mutant mouse embryos showed deficiency in definitive endoderm formation (Kanai-Azuma et al., 2002). The expression of Sox 17 increased by $\mathrm{d} 7$ in both cell lines (Figure 11B) and there was no significant difference in Sox17 expression between the wild type and the null mutant cell line. The mutant cells were not defective in endoderm formation.

Following, we checked the primitive ectoderm formation through monitoring the expression of Fgf5 (Fibroblast growth factor 5). Fgf5 is a marker of primitive ectoderm, which will later develop into neuroectoderm (Haub and Goldfarb, 1991; Hébert et al., 1991). In our experimental system, Fgf5 was induced $40 \mathrm{x}$ to $60 \mathrm{x}$ in $r y b p^{-/}$and $r y b p^{+/+}$, respectively, at the 
early phase of EB formation (d3) and later (d7) declined in both cell lines (Figure 11C). This result confirmed that the primitive ectoderm formation was initiated in both cell lines.

These results showed that the formation of all major germ layers was properly executed in the rybp null mutant cell line.
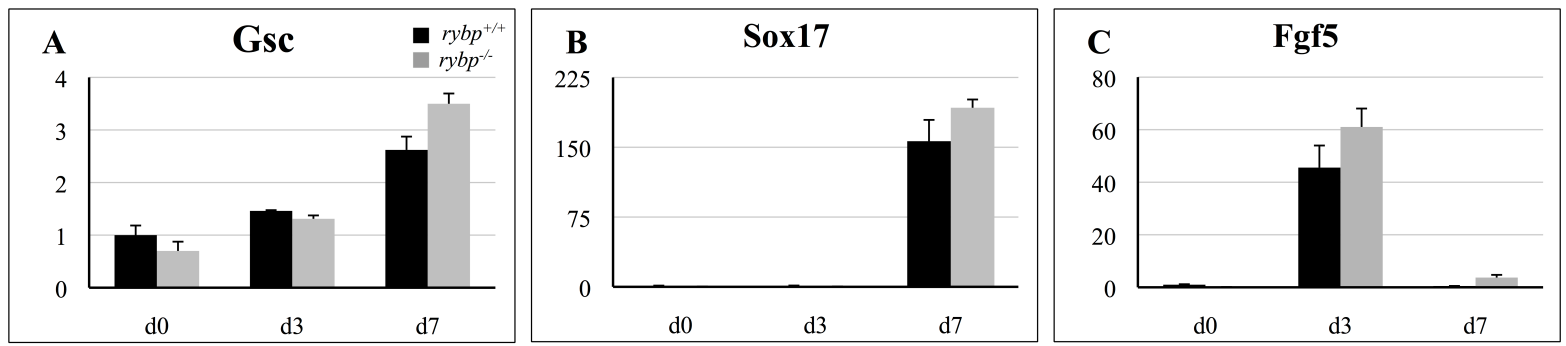

Figure 11 - Gene expression changes of germline markers Gsc (mesoderm), Sox17 (endoderm) and Fgf5 (primitive ectoderm) showed no differences

Relative gene expression analysis of Gsc (A), Sox17 (B) and Fgf5 (C) by qRT-PCR showed that the major germ layer formation was not defective in lack of Rybp. The expression of the indicated markers was normalized to Hprt expression. Means are standard deviation $\pm S D$. Values of $p<0.05$ were accepted as significant $(* p<0.05 ; * * p<0.01$; *** $p<0.001)$. Statistical method: T test type 3.

\subsection{Lack of Rybp accelerated neural progenitor formation}

After examination of germ layer markers, we analyzed the relative gene expression of key early neural markers (e.g. Nestin, Pax6, NeuroD1) in both cell lines to gain information whether the neuroectoderm formation from the primitive ectoderm is affected in absence of Rybp.

Nestin is an early marker of neural differentiation and widely employed marker of multipotent NSCs of neuroectoderm (Lendahl et al., 1990). Once the cells become differentiated, Nestin expression is downregulated (Park et al., 2010). As expected, at the time of neural induction (d7, RA treatment), Nestin was strongly upregulated in both cell lines (Figure 12A). Nestin expression increased further after plating of the cells (d10) and its level decreased only at later phases of neural differentiation (d14) in both cell lines (Figure 12A). Notably, Nestin expression was more robust in the $r y b p^{-/-}$cell line compared to the $r y b p^{+/+}$at $\mathrm{d} 10$. 
Immunocytochemistry with Nestin antibody confirmed the presence of NSCs and NPCs in both cell lines with stronger expression in the $r y b p^{-/}$cells at $\mathrm{d} 10$ (Figure 13AC). By the endpoint of the experiment (d14) the number of Nestin expressing cells were reduced in both cell lines (Figure 13AC). These results suggested that early neural processes took place in a greater extent in absence of functional Rybp.
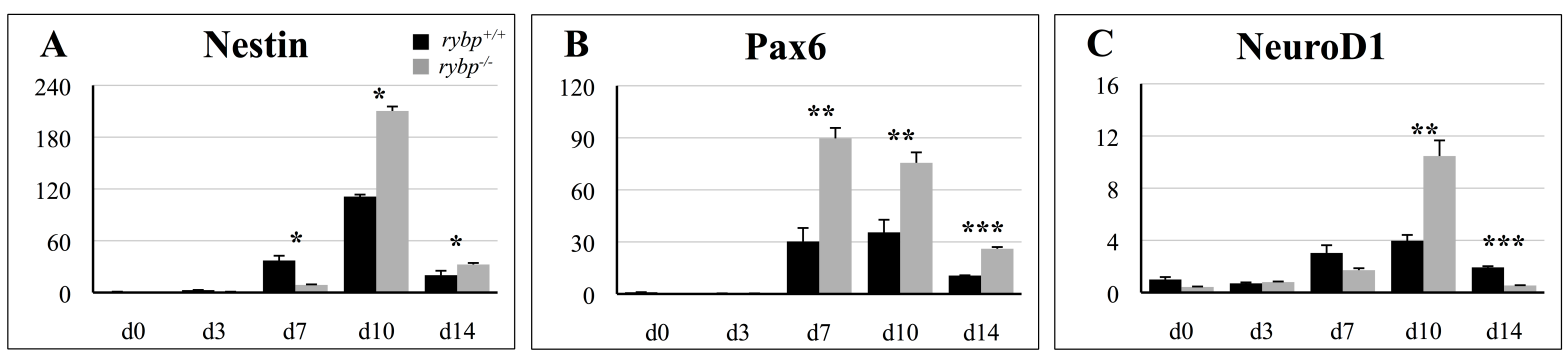

Figure 12 - Gene expression analysis showed upregulation of early neural markers (Nestin,

\section{Pax6, NeuroD1) in the mutant}

Relative gene expression analysis of Nestin (A), Pax6 (B) and NeuroD1 (C) by qRT-PCR showed elevated expression of early neural markers in rybp null mutant neural cultures in comparison to wild type. The expression of the indicated markers was normalized to Hprt expression. Means are standard deviation $\pm S D$. Values of $p<0.05$ were accepted as significant $\left({ }^{*} p<0.05 ; * * p<0.01 ; * * * p<0.001\right)$. Statistical method: T test type 3.

Pax6 gene is required for the initiation of neural differentiation (Ericson et al., 1997) but later it has to be downregulated since its high level inhibits terminal differentiation (Bel-Vialar et al., 2007). Relative gene expression analysis revealed that Pax6 was upregulated after the RA treatment (d7) (Figure 12B) and its level decreased at later timepoints of neural differentiation (d14) in the wild type cells. Expression of Pax6 was higher after neuroectodermal induction in the $r y b p^{-/}$cells compared to the wild type (Figure 12B). Pax6 immunostaining visualized the distribution of Pax6 positive cells in the wild type and mutant neural cell cultures (Figure 13B). The Pax6 signal was stronger in the mutant cultures in all examined time points (Figure 13BD). In both cell lines, the number of Pax6 positive cells was the highest at d10, when early differentiation events take place. These results correlate with the data of Pax6 qRT-PCR analysis and indicate an abundance of Pax6 positive cell population in the rybp null mutants. 
A
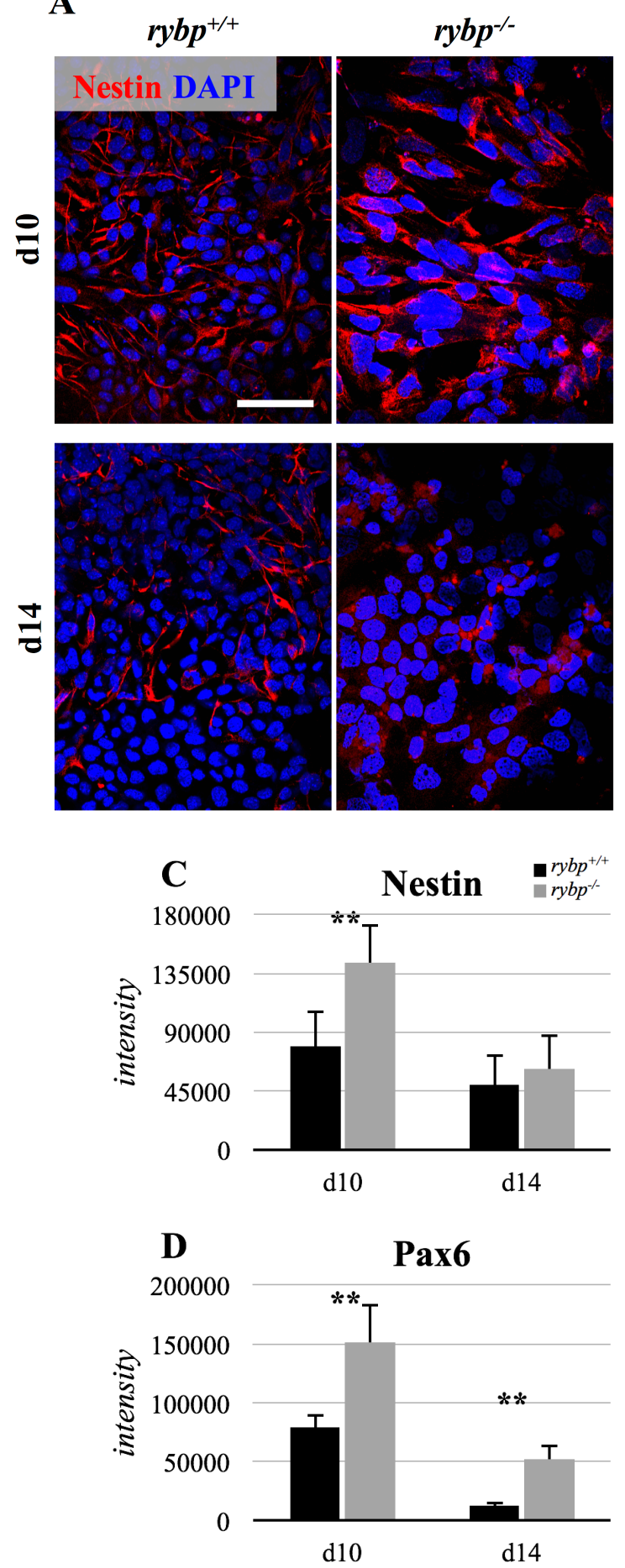

B
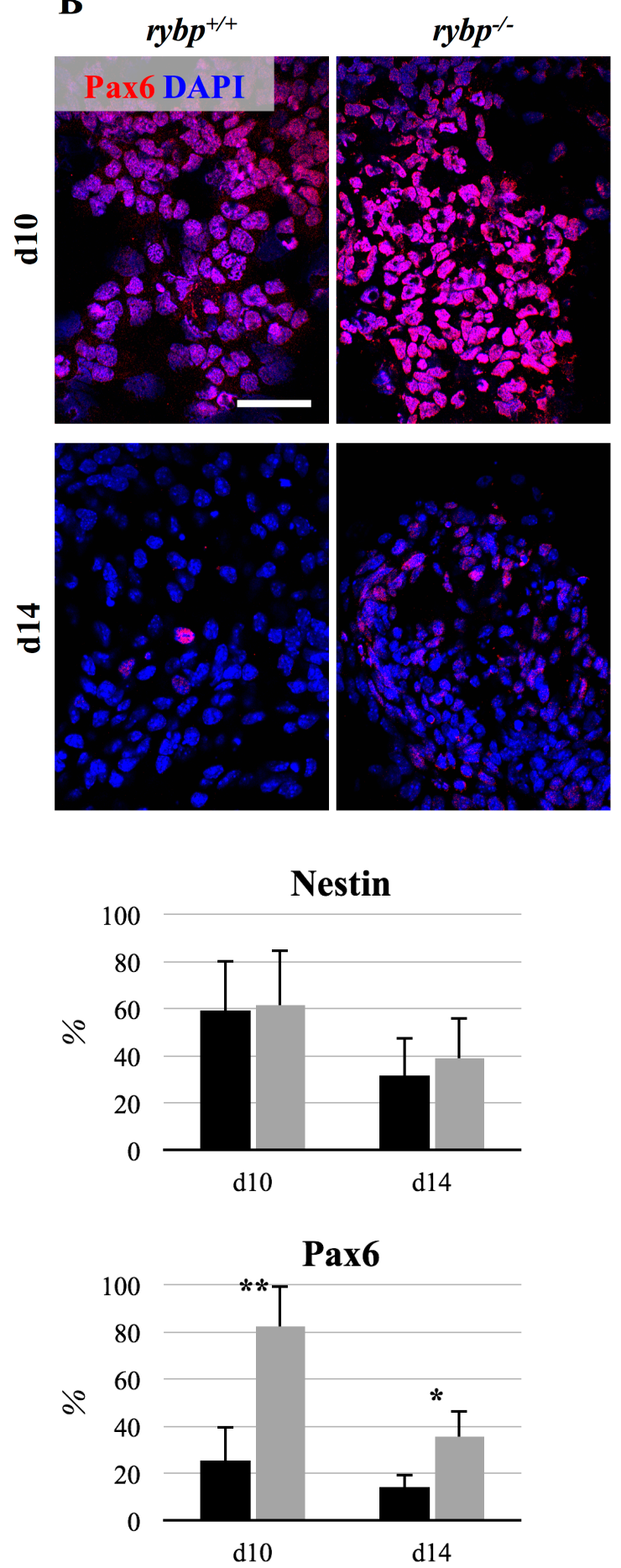

Figure 13 - Rybp deficient cells showed impaired protein expression of neural markers during in vitro neural differentiation

Immunocytochemical analysis of in vitro differentiated neural cultures after plating (d10, d14) showed altered expression on early neural markers Nestin (A) and Pax6 (B). Both markers 
showed elevated expression in the mutant. Objective: 60x. Scale bars: $60 \mu \mathrm{m}$. Semiquantification of Nestin $(\boldsymbol{C})$ and Pax6 (D) levels and the percentage of immunopositive cells. On the left panels vertical axis indicates the intensity of the fluorescence signal of the immunopositive cells, on the right panels vertical axis indicates the percentage of the immunopositive cells. Means are standard deviation. Values of $p<0.05$ were accepted as significant $(* p<0.05 ; * * p<0.01 ; * * * p<0.001)$. Statistical method: T test type 3.

NeuroD1 is a transcription factor, which is essential for terminal neuronal commitment of neural progenitors (Boutin et al., 2010). Relative gene expression analysis by qRT-PCR showed that NeuroD1 was mildly expressed after RA treatment (d7) in both cell lines (Figure 12C). The expression level of NeuroD1 was significantly higher at early stage (d10) in the mutant cell line compared to the wild type. The expression of NeuroD1 decreased by the end of differentiation $(\mathrm{d} 14)$ in the $r y b p^{-/-}$cells whilst there was only a minor decrease in its level in the $r y b p^{+/+}$cells. At d14, NeuroD1 expression was higher in the wild type cells compared to the mutants. This also confirmed that the characteristics of NPCs were altered in the rybp null mutants: the premature differentiation of NPCs was accelerated at the mid-phase (d10) but it was attenuated by the end of differentiation (d14).

\subsection{Absence of Rybp obscured terminal differentiation of neural lineages}

After examining the early markers of neural differentiation, we analyzed the relative gene expression of key late neural markers (e.g. Tubb3, NeuN, Gfap, Olig2) to clarify whether the formation of mature neural cell types (neurons, astrocytes, oligodendrocytes) is defective in the rybp null mutant cells.

Tubb3 is a well-known neuronal cell marker, which contributes to the microtubule stability in axons (Black et al., 1984). It plays a critical role in proper axon guidance, maintenance and axonal transport (Ferreira and Caceres, 1992) and is also expressed in the postmitotic phase of differentiating neurons (Fanarraga et al., 1999). Relative gene expression analysis by qRT-PCR showed that Tubb3 expression was elevated at early stage (d10) in both cell lines but its expression declined in the $r y b p^{-/-}$cells at later stage of neural differentiation (d14) while its 
level remained high in the wild type (Figure 14A). In order to visualize the developing network of neural cell culture spatiotemporally we stained the cells with Tuj1 antibody, which marks Tubb3 positive cells. The assessment of Tuj1 staining (Figure 15AC) showed that neurite processes and axon-like structures started to develop in both cell lines, however, the $r y b p^{+/+}$ outgrowths exhibited a more complex and dense network than the mutants. The reduced density of nerve fibers by ICC in the rybp null mutant cell line was consistent with the data on diminished amount of nerve bundles on Tubb3 by qRT-PCR analyses. These data suggest that a normal level of Rybp is important for the proper development of neurons.
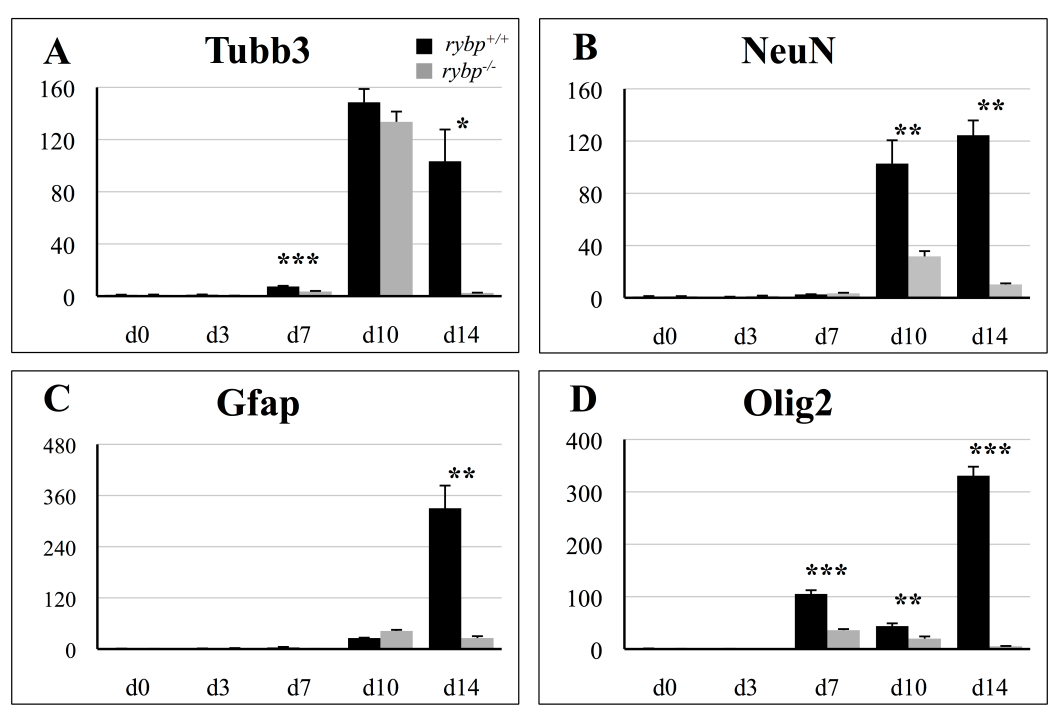

Figure 14 - Gene expression changes of markers of late neural differentiation (Tubb3, NeuN, Gfap, Olig2) showed terminal differentiation deficiency

Relative gene expression analysis of Tubb3 (A), NeuN (B), Gfap (C) and Olig2 (D) by $q R T$ PCR showed that late neural markers were downregulated in rybp null mutant neural cultures compared to wild type. The expression of the indicated markers was normalized to Hprt expression. Means are standard deviation $\pm S D$. Values of $p<0.05$ were accepted as significant $\left({ }^{*} p<0.05 ; * * p<0.01 ; * * * p<0.001\right)$. Statistical method: T test type 3.

In order to confirm the presence of mature neurons in our cell cultures we assessed the relative gene expression changes of postmitotic neuronal marker NeuN, which marks the nuclei of maturing and differentiated neurons (Mullen et al., 1992). As expected, qRT-PCR analysis showed that NeuN was abundantly expressed in the plated wild type neural cultures $(\mathrm{d} 10, \mathrm{~d} 14)$ 
but its level stayed constantly low in the mutants (Figure 14B). This indicated that much less mature neurons formed in the rybp null mutant culture $(\mathrm{d} 10, \mathrm{~d} 14)$ and further confirmed the compromised differentiation ability of rybp null NPCs.

This observation tempted us to speculate whether this defect is specific to neurons or other cell types like astrocytes and oligodendrocytes are also affected in the absence of Rybp. Therefore, we next analyzed whether cells lacking functional Rybp are able to generate astrocytes as well. In order to do so, we had performed relative gene expression analysis by qRT-PCR in both cell lines for Gfap, which is a commonly accepted intermediate filament marker of radial glias and astrocytes (Bignami et al., 1972; Eng et al., 1971). Our analysis revealed that the level of Gfap was elevated over 300x in the wild type cells (Figure 14C; d14). In comparison its level stayed low in the rybp null mutants (Figure 14C; d14). We also analyzed the spatial distribution of Gfap by immunostaining and found that there was no Gfap positive cell in the mutant neural cultures (Figure 15BD). This suggested that the astrocyte differentiation was also defective in the mutant cells.
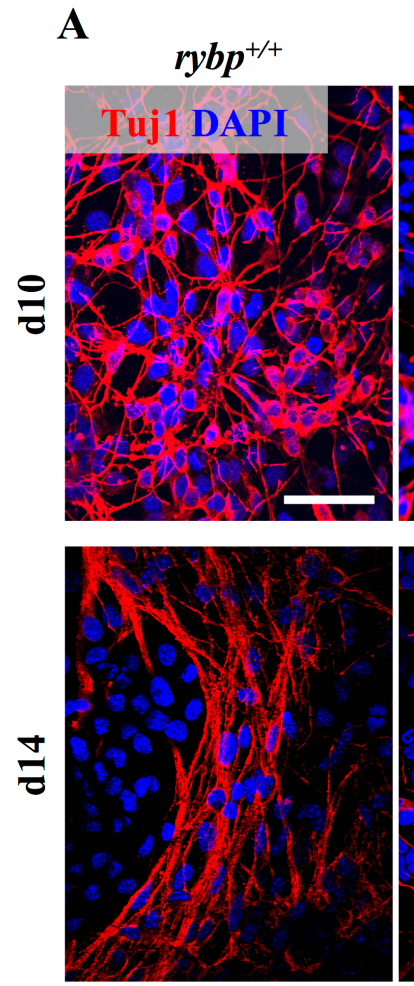

B
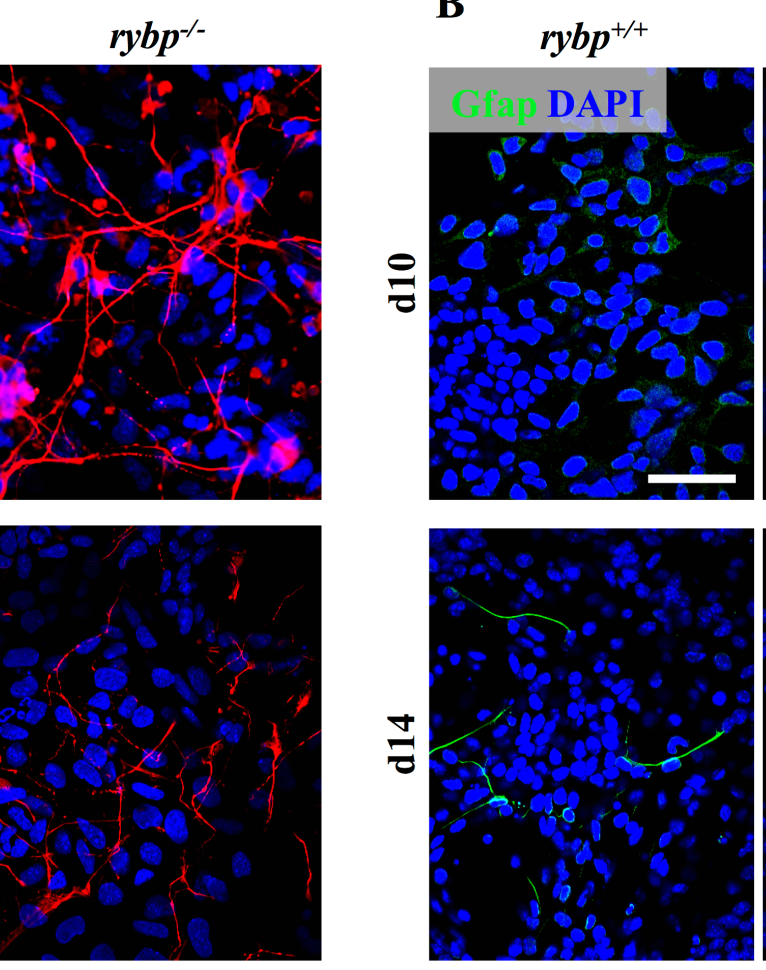

$r y b p^{-/-}$
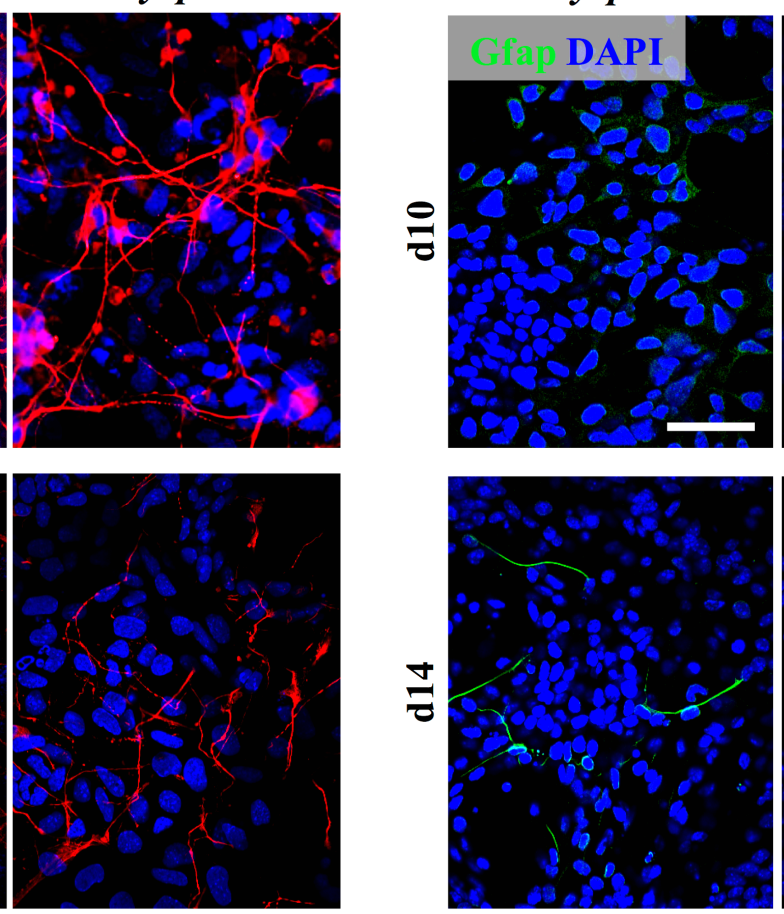

$r y b p^{-/-}$
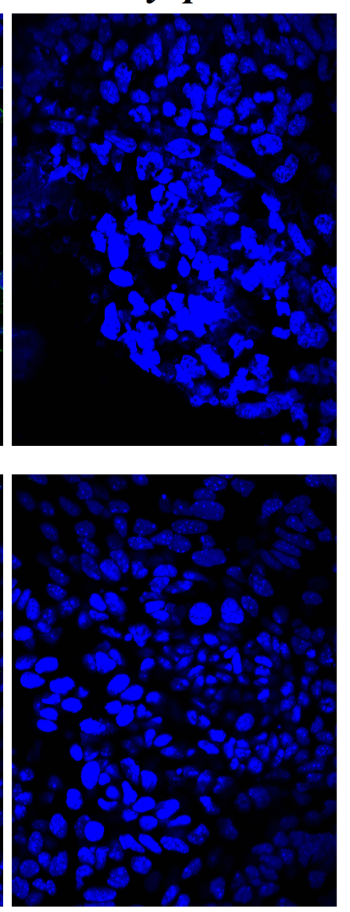

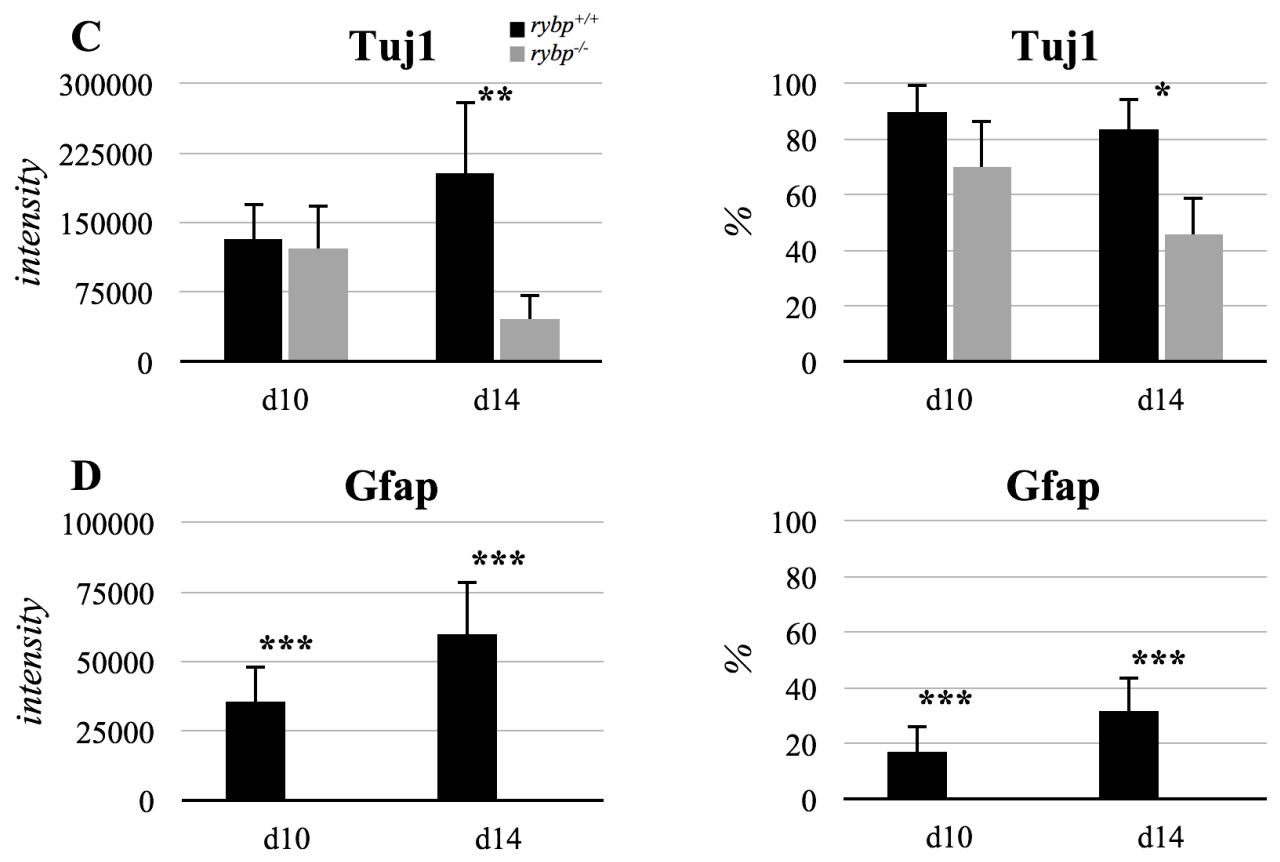

Figure 15 - Rybp deficient cells showed impaired protein expression of late neural markers during in vitro neural differentiation

Immunocytochemical analysis of in vitro differentiated neural cultures after plating (d10, d14) showed altered expression on neural cell marker Tuj 1 (A), which expressed in axon of maturing neurons and in postmitotic neurons. (B) Immunostaining of astrocyte marker, Gfap showed a small amount of astrocyte-like cells in wild type culture, which was absent in the mutant. Both markers were nearly invisible in the rybp ${ }^{-/}$cell culture at 114 compared to wild type, which indicated defects in late neural processes. Objective: 60x. Scale bars: $60 \mu \mathrm{m}$. Semiquantification of Tuj1 (C) and Gfap (D) levels and the percentage of immunopositive cells. On the left panels vertical axis indicates the intensity of the fluorescence signal of the immunopositive cells, on the right panels vertical axis indicates the percentage of the immunopositive cells. Means are standard deviation. Values of $p<0.05$ were accepted as significant $(* p<0.05 ; * * p<0.01 ; * * * p<0.001)$. Statistical method: T test type 3.

We also investigated if the absence of Rybp has influence on other types of glial cells or it is specific for astrocytes. For this purpose, we measured the relative expression level of Olig2 by qRT-PCR. Olig2 is a marker gene for oligodendrocytes (Mizuguchi et al., 2001; Takebayashi et al., 2002; Zhou et al., 2000). Oligodendrocyte differentiation normally started by d7 and peaked by $\mathrm{d} 14$ (Figure 14D $r y b p^{+/+}$). In contrast, the $r y b p^{-/-}$cells expressed $60 \mathrm{x}$ less Olig2 
mRNAs at d14 compared to the wild type (Figure 14D). This demonstrated that oligodendrocyte differentiation was also strongly impaired in the absence of functional Rybp.

\subsection{Dendrite and axon formation was impaired in the absence of Rybp}

Next, we wanted to specify the nature of the defective neural differentiation so we investigated the formation of dendrite and axon formation with lineage specific markers.

In mature neurons Map2 (Microtubule-associated protein 2) is preferentially localized to dendrites (Caceres et al., 1984), whereas Tau (also known as MapT (Microtubule-associated protein tau) or $\tau$ ) labels axons (Kosik et al., 1986; Paglini et al., 2000). Relative expression changes of Map2, evaluated with qRT-PCR, revealed that its expression peaked by $\mathrm{d} 10$ (400x) and remained high in the wild type neural cultures $(\mathrm{d} 14,250 \mathrm{x})$ but stayed low in the mutant (Figure 16A). Expression of Tau mRNAs was the highest by d14 in the wild type (55x), but its level was nearly absent in the mutant (Figure 16B).
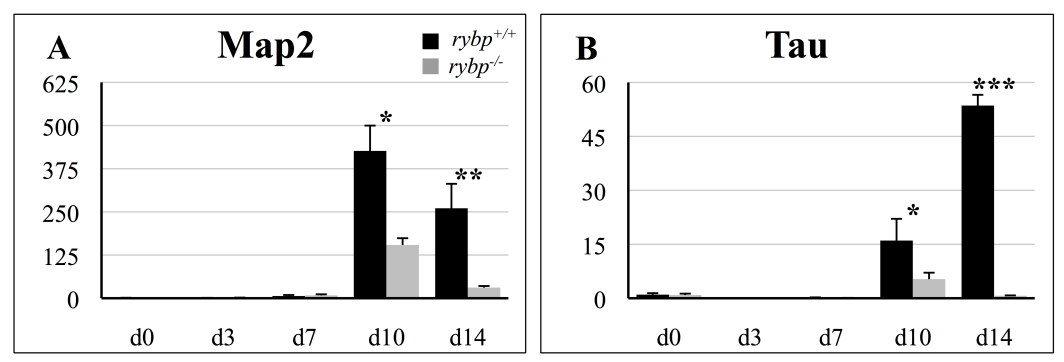

Figure 16 - Gene expression changes of dendritic (Map2) and axonal (Tau) markers showed alteration in lack of Rybp

Relative gene expression analysis of Map2 (A) and Tau (B) by qRT-PCR showed decreased expression of dendritic and axonal markers in rybp null mutant neural cultures compared to wild type. The expression of the indicated markers was normalized to Hprt expression. Means are standard deviation $\pm S D$. Values of $p<0.05$ were accepted as significant $(* p<0.05 ; * * p$ $<0.01 ; * * * p<0.001)$. Statistical method: T test type 3.

We co-stained Map2, with NSC marker RC2, and Tau, with neurofilament marker 2H3 to visualize the spatiotemporal distribution of the dendrites and axons in our neural cell cultures. 
We observed RC2-positive, 2H3-positive, Map2-positive and Tau-positive cells in each cell cultures, which indicated that both early neural progenitors and mature neuronal cells were present in both cell lines at the examined timepoints (Figure 17). The number of RC2 positive cells was higher in the mutant at both timepoints, which is in accordance with the results of the Nestin staining (Figure 13AC) and the Nestin qRT-PCR (Figure 12A). The number of 2H3 positive cells was lower in the mutant at $\mathrm{d} 14$ with a weaker signal, which is in accordance with Tuj1 results (Figure 13AC). Map2 and Tau staining showed that there were persistently more axonal and dendritic cells present at later timepoint (d14) in the wild type compared to the mutant. The formation of dendrites and axons from existing neural progenitors was defective in the absence of Rybp.

$\mathbf{A}$
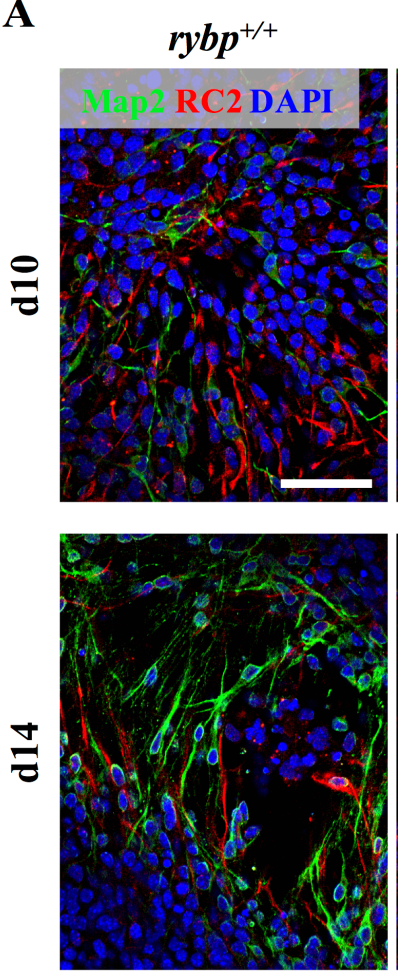

B
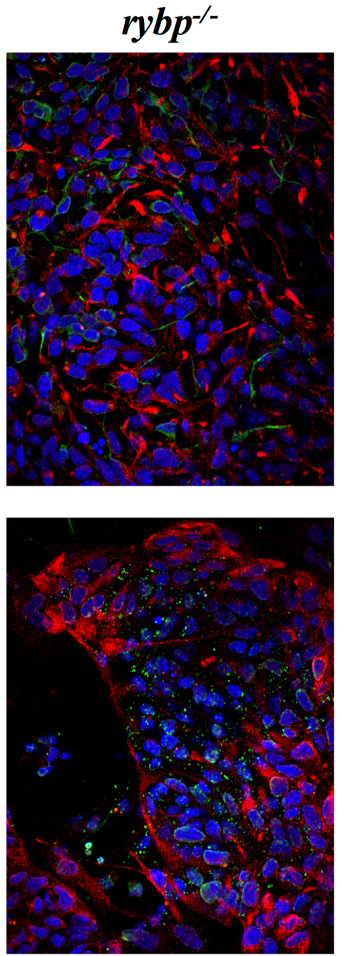
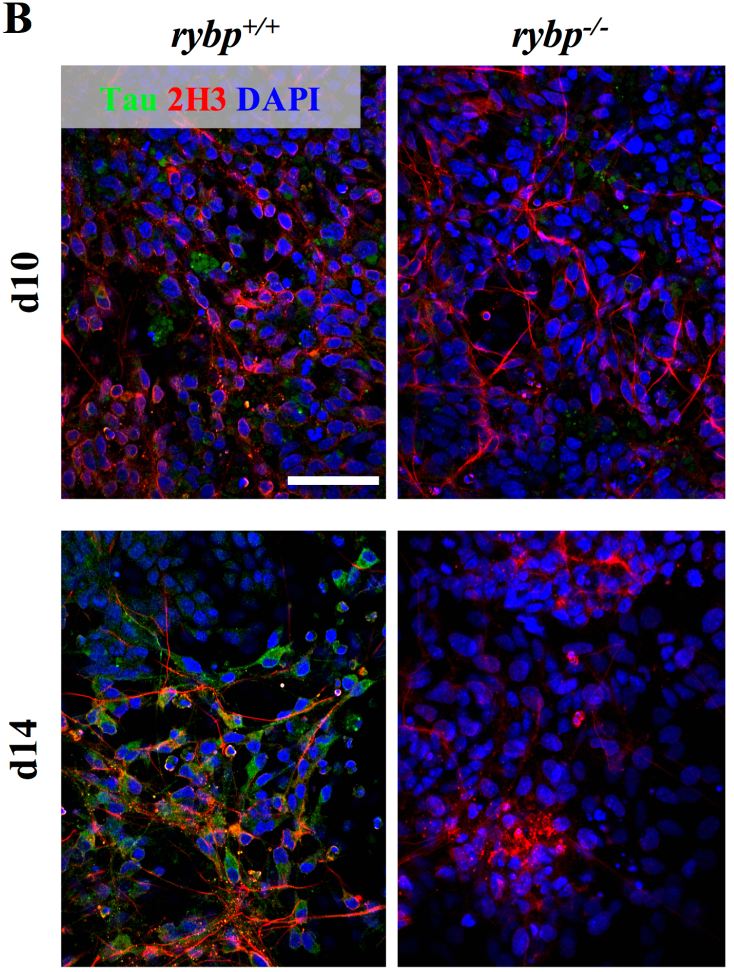

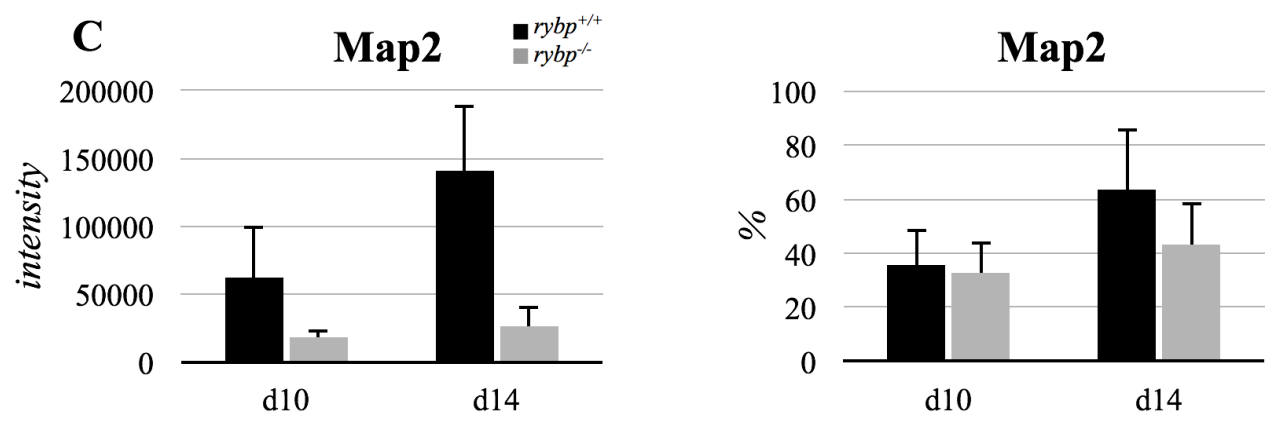

\section{D}

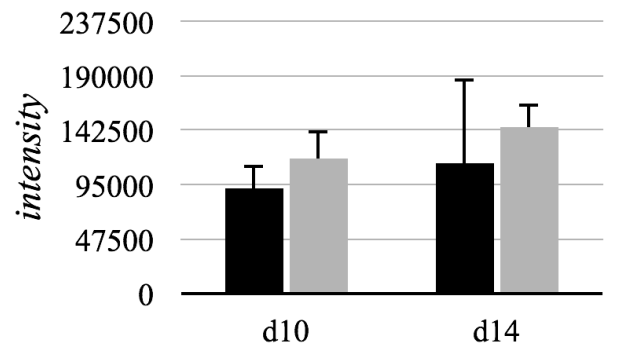

$\mathbf{E}$
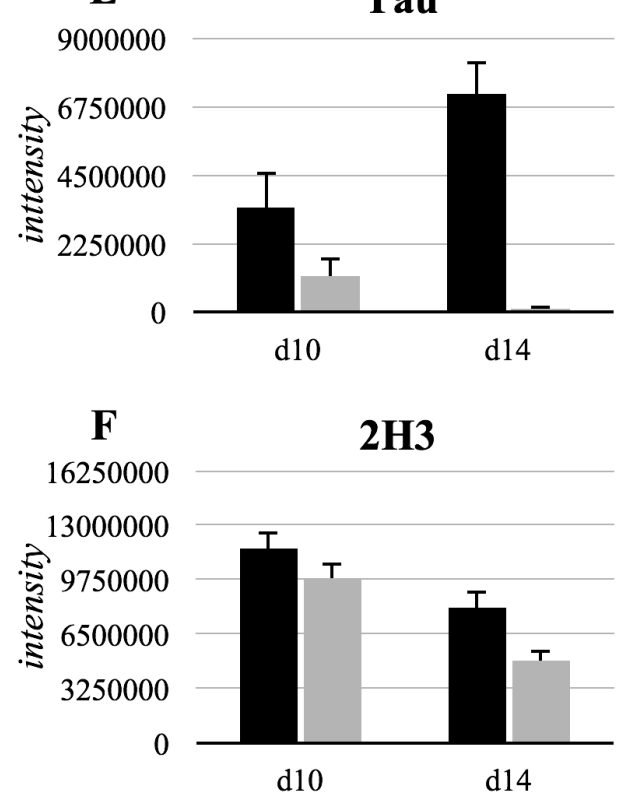

RC2
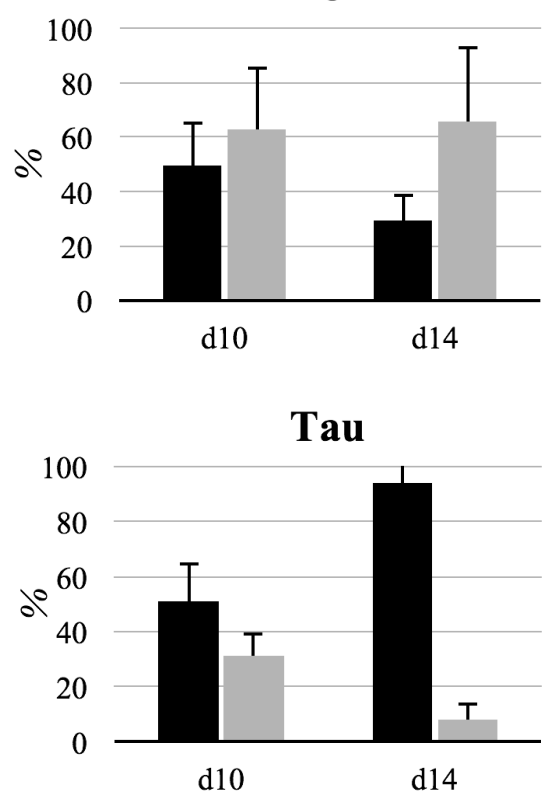

$2 \mathrm{H3}$

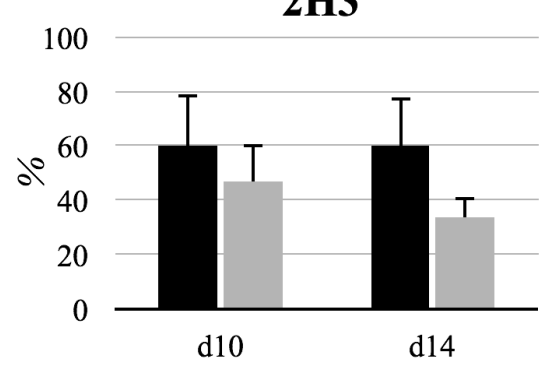

Figure 17 - Rybp deficient cells showed altered dendrite and axon formation through in vitro neural differentiation

(AB) Immunocytochemical analysis of in vitro differentiated neural cultures after plating (d10, d14) showed altered expression on neural progenitor marker RC2 (A)(red), neurofilament marker $2 H 3$ (B)(red), dendrite specific marker Map2 (A)(green) and axonal marker Tau (B)(green). While RC2 showed elevated expression in the mutant compared to the wild type, the number of Map2 positive, 2 H3 positive and Tau positive cells was lower. Objective: 60x. Scale 
bars: $60 \mu \mathrm{m}$. Semi-quantification of Map2 (C), RC2 (D), Tau (E) and $2 H 3$ (F) levels and the percentage of immunopositive cells. On the left panels vertical axis indicates the intensity of the fluorescence signal of the immunopositive cells, on the right panels vertical axis indicates the percentage of the immunopositive cells. Means are standard deviation. Values of $p<0.05$ were accepted as significant $(* p<0.05 ; * * p<0.01 ; * * * p<0.001)$. Statistical method: $T$ test type 3.

\subsection{Plagl1 was not induced in the rybp ${ }^{-/-}$cells during in vitro neural differentiation}

Based on the marked alterations in gene expression described above (Sox2, Pax6, Nestin, NeuroD1, Tubb3, NeuN, Gfap, Olig2, Map2, Tau) we had performed genome wide profiling by transcriptome analysis and compared the gene expression profile of the wild type and $r y b p$ null mutant ES cells (d0). We were wondering whether there is any gene, which expression level is influenced by the lack of Rybp. We paid special attention towards genes being important for neural differentiation. Several transcripts expressed differently in the two ES cell lines (Appendix C, Table S2, S3). One of the most downregulated genes in rybp null ES cells was Plagl1 (d0: fold change $=-13.86$, padj $=2.3 \cdot 10^{-5}$; the level of Plagl1 was $13.86 \mathrm{x}$ lower in the mutant compared to wild type and this change is significant), which gene has crucial role in mouse embryonic development (Chung et al., 2011; Ma et al., 2007; Valente and Auladell, 2001; Valente et al., 2005; Varrault et al., 2006; Yuasa et al., 2010).

To further investigate if Rybp impacts Plagll expression only in ES cells or the deficiency is sustained through the course of neural differentiation, we had checked the expression changes of Plagll mRNAs during in vitro neural differentiation of $r y b p^{+/+}$and $r y b p^{-/-}$ES cells. Gene expression analysis by qRT-PCR (Figure 18A) revealed that Plagl1 was strongly induced (300x) after the RA treatment (d7) during in vitro neural differentiation in the wild type cells and remained high until the end of differentiation (d14). However, in the rybp ${ }^{-/}$cells Plagl1 was not induced during the entire course of differentiation. After this, we wanted to test whether the difference in Plagl1 mRNA induction is also sustained at protein level. In order to visualize the spatiotemporal distribution of Plagll throughout the differentiation we performed immunocytochemistry of in vitro neural cultures with antibody against the Plagll protein 
(Figure 18BC). This confirmed that Plagll was visible in the nuclei of the wild type cells (Figure $\left.18 \mathrm{~B} ; r y b p^{+/+} \mathrm{d} 10, \mathrm{~d} 14\right)$ while in the $r y b p^{-/}$cells there is a complete lack of Plagl1 expression. These results showed that Plagll was absent in $r y b p^{-/}$cells during the entire course of neural differentiation and they were in agreement with our recent observation, that Plagl1 was not induced during in vitro cardiac differentiation of $r y b p^{-/-}$ES cells (Ujhelly et al., 2015).
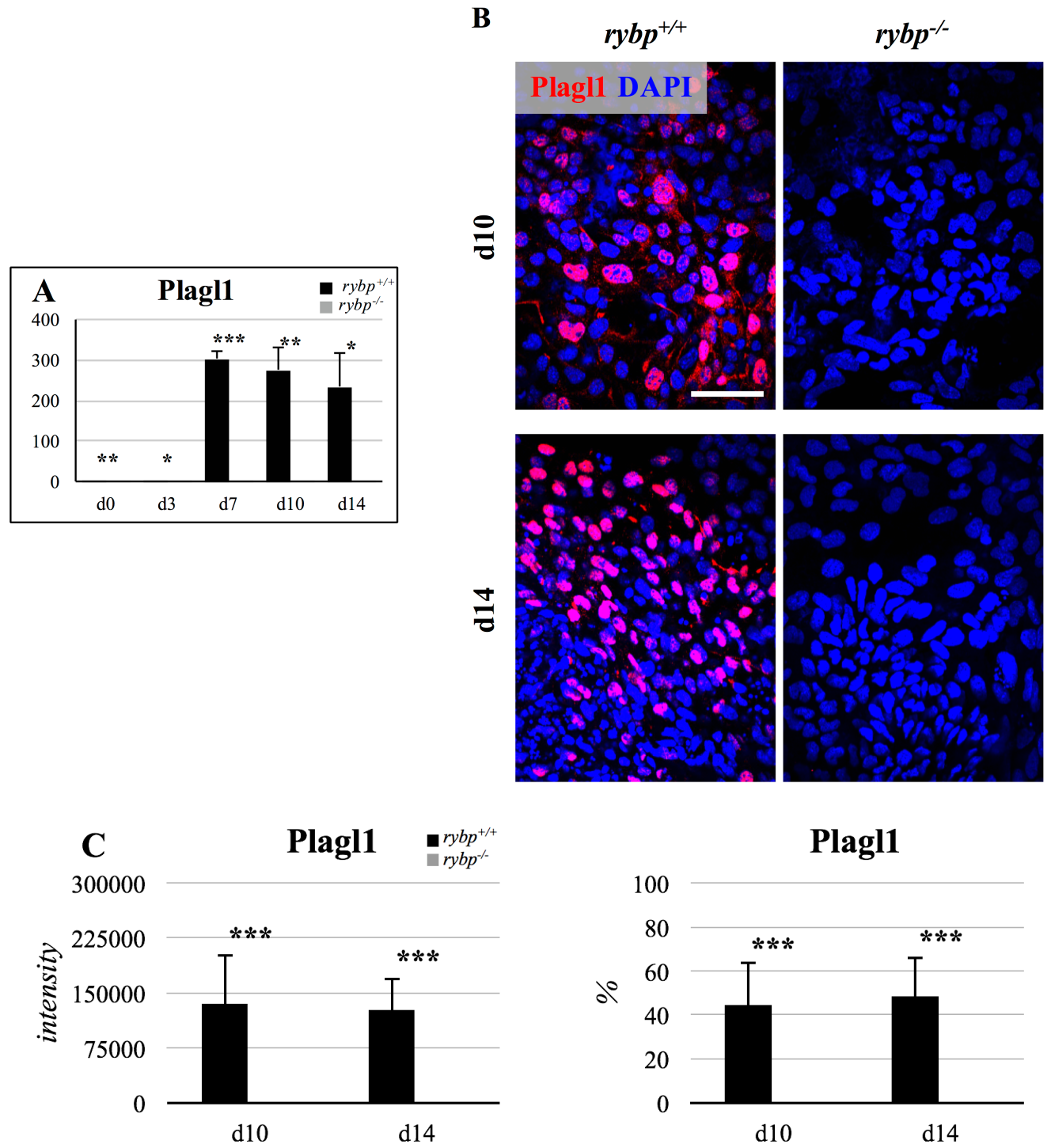

Figure 18 - Rybp null mutant cells did not show Plagll expression

(A) Relative gene expression analysis by qRT-PCR showed that Plagll induction was deficient in the null mutant cells. The expression of Plagl1 was normalized to Hprt expression. Means are standard deviation $\pm S D$. Values of $p<0.05$ were accepted as significant $(* p<0.05 ; * * p$ 
$<0.01$; *** $p<0.001)$. Statistical method: T test type 3. (B) Immunocytochemistry with antibody against Plagll revealed that Plagll was expressed in the nucleus of rybp ${ }^{+/+}$cells but it was completely absent in rybp ${ }^{-/-}$cells. Objective: $60 x$. Scale bar: $60 \mu m$. Semi-quantification Plagl1 (C) level and the percentage of immunopositive cells. On the left panel vertical axis indicates the intensity of the fluorescence signal of the immunopositive cells, on the right panel vertical axis indicates the percentage of the immunopositive cells. Means are standard deviation. Values of $p<0.05$ were accepted as significant $(* p<0.05 ; * * p<0.01$; *** $p<$ 0.001). Statistical method: T test type 3.

\subsection{Lack of Rybp did not effect cell-cycle distribution but altered apoptosis}

It was previously described that Plagl1 promotes cell-cycle withdrawal (Valente and Auladell, 2001) and has important function in apoptosis (Spengler et al., 1997). Since Rybp is also involved in regulation of apoptosis (Stanton et al., 2007; Zheng et al., 2001) and we had no information about the context of cell-cycle progress we have measured the distribution of cellcycle phases and the rate of apoptosis in wild type and rybp null mutant cells during neural differentiation by FACS analysis (described in Materials and methods). In brief, we incubated the cells with BrdU for $1 \mathrm{~h}$, fixed with ethanol, denatured with $\mathrm{HCl}$, neutralized with $\mathrm{Na}_{2} \mathrm{~B}_{4} \mathrm{O}_{7}$, permeabilized with Tween20, then the cells were incubated with the primary monoclonal antibody anti-BrdU, then with Alexa Fluor ${ }^{\circledR}$ 647-labeled secondary antibody. The cells were resuspended in propidium-iodide (PI), then FACS analysis was performed.

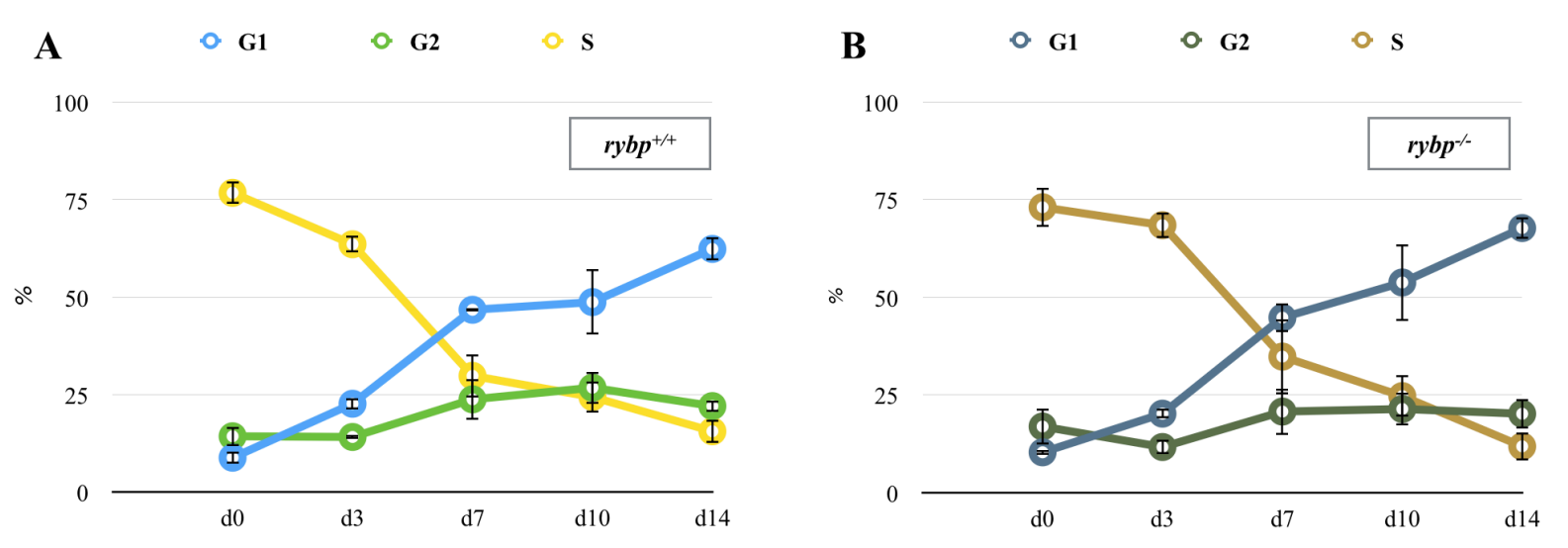


Figure 19 -Cell-cycle changes in rybp ${ }^{+/+}$and rybp ${ }^{-/-}$ES cells during neural differentiation There were no significant differences in the distribution of cell-cycle phases during neural differentiation between wild type $(\boldsymbol{A})$ and rybp null mutant $(\boldsymbol{B})$ cells. Means are standard deviation. Values of $p<0.05$ were accepted as significant $(* p<0.05 ; * * p<0.01$; *** $p<$ 0.001). Statistical method: T test type 3.

In the course of in vitro neural differentiation, as expected, the number of cells in S phase was gradually decreasing, while concomitantly the number of cells in G1 phase was increasing in the wild type (Figure 19). Our results showed that the distribution of cell-cycle phases was near identical in the mutant. This suggested that withdrawal of Rybp from the cells had no significant effect on cell-cycle progression during neural differentiation.

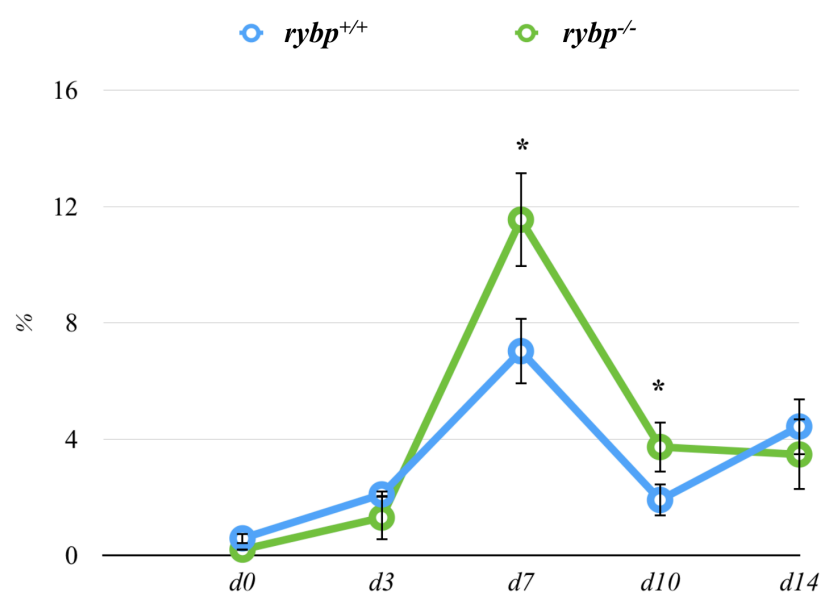

Figure 20 - Rate of apoptosis in differentiating rybp ${ }^{+/+}$and rybp ${ }^{-/-}$cells

Apoptosis determined during neural differentiation of wild type and rybp null mutant cells by PI staining and FACS analysis. In the mutant culture the number of apoptotic cells was higher at 77 and 110 compared to the wild type. Vertical axis shows the percentage of apoptotic cells. Means are standard deviation. Values of $p<0.05$ were accepted as significant $\left(^{*} p<0.05 ; * *\right.$ $p<0.01 ; * * * p<0.001)$. Statistical method: T test type 3.

We also examined the rate of apoptosis in both cell cultures by FACS analysis of PI stained nuclei of differentiating cells. Our results showed that there were differences in the rate of apoptosis during neural differentiation between wild type and rybp null mutant cell lines. The number of apoptotic cells was higher in the mutant at $\mathrm{d} 7$ and $\mathrm{d} 10$ (Figure 20) compared to wild 
type, $11.5 \%$ compared to $7 \%$, and $3.7 \%$ compared to $1.9 \%$, respectively. It seems that the lack of Rybp has no affect on cell-cycle, but influences apoptosis during in vitro neural differentiation.

\subsection{Rybp was able to activate Plagl1 through its promoter}

Some of the developmental defects of Plagl1 mutant mice (Chung et al., 2011; Yuasa et al., 2010) are strikingly similar to the phenotype of the $r y b p^{+/}$mice (including defects of neural tube closure, defects in cortex and cerebellum development) (Figure 4) (Pirity et al., 2005). In addition, Rybp can regulate through E2f (E2 promoter binding factor) binding sites (Schlisio et al., 2002; Trimarchi et al., 2001), which are also present in Plagl1 promoter. These raise the possibility that Rybp can regulate Plagll promoter, so we examined this possibility with luciferase reporter assay.

We used Plagl1 gene promoter luciferase reporter construct (pGL3.Plagl1-Luc) and HA-tagged Rybp vector (pcDNA3.1-RybpHA) to evaluate the transactivational potency of Rybp to Plagl1 expression. Rybp expression vectors were cotransfected at different dosages $(1 \mu \mathrm{g}, 5 \mu \mathrm{g}, 25$ $\mu \mathrm{g})$ with Plagl1 promoter constructs into COS7 cells, then after two days luciferase activity was measured from the cell lysates. Our results showed that Rybp activated the Plagl1 promoter more than 1500 fold (Figure 21). This induction was up to 5 fold if it was compared to the basic activity of the Plagl1 vector. The fold increase was similar at cotransfections of different dosages of Rybp vectors with Plagll promoter construct. In our experiments Rybp could activate Plagl1 promoter and this effect was unlikely dosage dependent. 


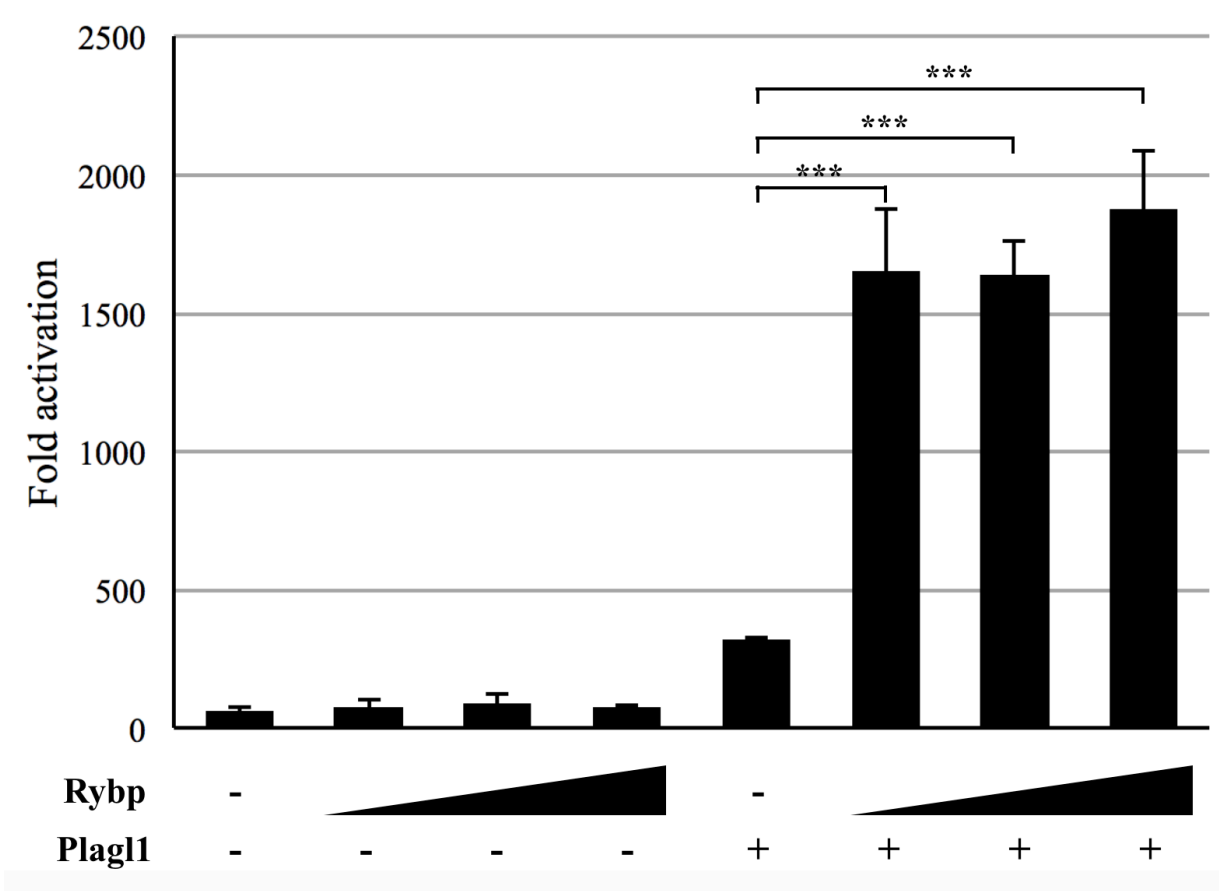

\section{Figure 21 - Rybp activated Plagl1 gene expression through its promoter}

COS7 cells were transfected with Rybp expression plasmid in increasing dosages (1 $\mu \mathrm{g}, 5 \mu \mathrm{g}$, $25 \mu \mathrm{g}$ ) and with Plagl1 promoter luciferase reporter construct. Luciferase activity of the transfected cell lysates were measured 48 hours after transfection. Values were expressed as fold increase in luciferase activity. Results showed that cotransfection of Plagll vector with Rybp vector increased luciferase activity, which indicated that Rybp activated Plagl1 expression through its promoter. Means are standard deviation. Values of $p<0.05$ were accepted as significant $\left({ }^{*} p<0.05 ; * * p<0.01 ; * * * p<0.001\right)$. Statistical method: T test type 3. 


\section{DISCUSSION}

The current thesis aimed to elucidate the molecular events underlying of the $r y b p$ heterozygous mice phenotype (Pirity et al., 2005) and to investigate the role of PcG protein Rybp in neural lineage specification. Considerable attention has focused on the characterization of ES cell derived neural lineages in the absence of functional Rybp. The contribution of Rybp to neural lineage commitment is particularly interesting since in vivo evidence has been already provided that Rybp is important for neural development and it is broadly expressed in different cell types of the CNS. Furthermore, misexpression of PRC members has been associated with a broad range of cancers, suggesting that they have essential role in maintaining cell identity and disease

development. Downregulation of Rybp was shown in glioblastomas and other types of tumors and overexpression of Rybp inhibited tumor growth of liver cancer cells and sensitized them for consequent chemotherapy treatment in vivo (Chen et al., 2009; Li et al., 2013; Novak and Phillips, 2008; Taylor et al., 2010; Voruganti et al., 2015; Wang et al., 2014). All of this recent observations support that Rybp is a candidate new biomarker for predicting the prognosis of cancer patients (Voruganti et al., 2015; Wang et al., 2014). Based on this, a better understanding of the processes governed by Rybp is highly desirable.

\subsection{Rybp is essential for the development of mature neural cell types}

Results from this project broaden our knowledge on the characteristics of stem cells and the process of neural differentiation. We found that the formation of NSCs and NPCs is accelerated in absence of Rybp, however these cells formed less mature neural cell types from existing progenitors than the wild type counterparts. This phenotype cannot be caused by improper silencing of key pluripotency genes (e.g., Oct4, Nanog) since our results demonstrated that this process is a well-coordinated event in the absence of Rybp during in vitro neural differentiation. At the same time, the expression of early neural markers is remarkably altered in $r y b p^{-/-}$cells. One of the most important early neural marker, which level is altered in rybp null mutant, is Pax6 (Gajović et al., 1997). It is a key transcriptional factor, whose level needs to be upregulated at the beginning of neural development since Pax6 plays important role in establishing NPC 
pool during the vertebrate nervous system development (Ericson et al., 1997). At the same time downregulation of Pax 6 is also necessary for the forthcoming, late neural differentiation. In our assays when Rybp is absent, the level of Pax6 stays elevated. Since high level of Pax6 obstructs terminal differentiation of NPCs, it is possible that this "excess" level of Pax6 helps to keep NPCs at the early stage of differentiation and inhibits the forthcoming late neural processes in the $r y b p^{-/}$cells (Bel-Vialar et al., 2007) (Figure 23). Upregulation of Nestin and NeuroD1 also confirms that early neural processes are accelerated in the lack of Rybp compared to the wild type. Nevertheless, the pool of Sox 2 positive cells is reduced in the rybp null mutants earlier than in the wild type neural cultures. Sox 2 is not only a critical factor for maintaining pluripotency and directing the differentiation of stem cells to NPCs, but it is also important for maintaining the properties of NPCs (Graham et al., 2003). Downregulation of Sox 2 resulted in progenitor cells led to lose their capability to proliferate and terminally differentiate (Taranova et al., 2006). Since others already described that the striking increase of Pax6 can partially rescue the Sox2 mutant phenotype (Matsushima et al., 2011), it cannot be excluded that increased level of Pax6 in the rybp null mutant compensates the effect of low level of Sox2. It is possible that lack of Rybp alters the balance among major transcription factors governing the NPC pool generation and consequent differentiation events. By changing the expression level of one or more members in these circuits will shift the finely tuned balance and initiate premature differentiation. Alternatively, this suboptimal balance may exhaust the NPC pool, which obscures consequent differentiation events. Since Rybp is a moonlighting protein, and is involved in such diverse biological functions as ubiquitination (Tavares et al., 2012), apoptosis (Stanton et al., 2007; Zheng et al., 2001) and transcriptional repression (Schlisio et al., 2002), it may have multiple roles in regulating neural differentiation as well. Further complicates the situation that Yaf2, the other member of the Rybp/Yaf2 gene family, may compensate the lack of Rybp at certain extent (Kaneko et al., 2003; Sawa et al., 2002).

Importantly, decreased level of late neuronal markers (Tubb3, NeuN, Gfap, Olig2) indicates that the maturation of neurons, astrocytes and oligodendrocytes is deficient in the rybp null mutant cells (Figure 22) (Kovacs et al., 2016). This results showed that the process of differentiation towards all mature neural cell types rather than to a specific lineage is impaired in the lack of Rybp. This also supported by the fact that Map2 and Tau expressed at lower amount in the mutant compared to wild type and indicates defective formation of axons and 
dendrites in the rybp null mutant. The formation of neurite processes and their organization into complex network is influenced by the presence or absence of Rybp, which brings up the possibility that Rybp may have a role in microtubule remodeling during neurite extension. These findings are in accordance with previously described in vivo work demonstrating that Rybp is a critical factor for CNS development (Gao et al., 2012; Pirity et al., 2007, 2005).
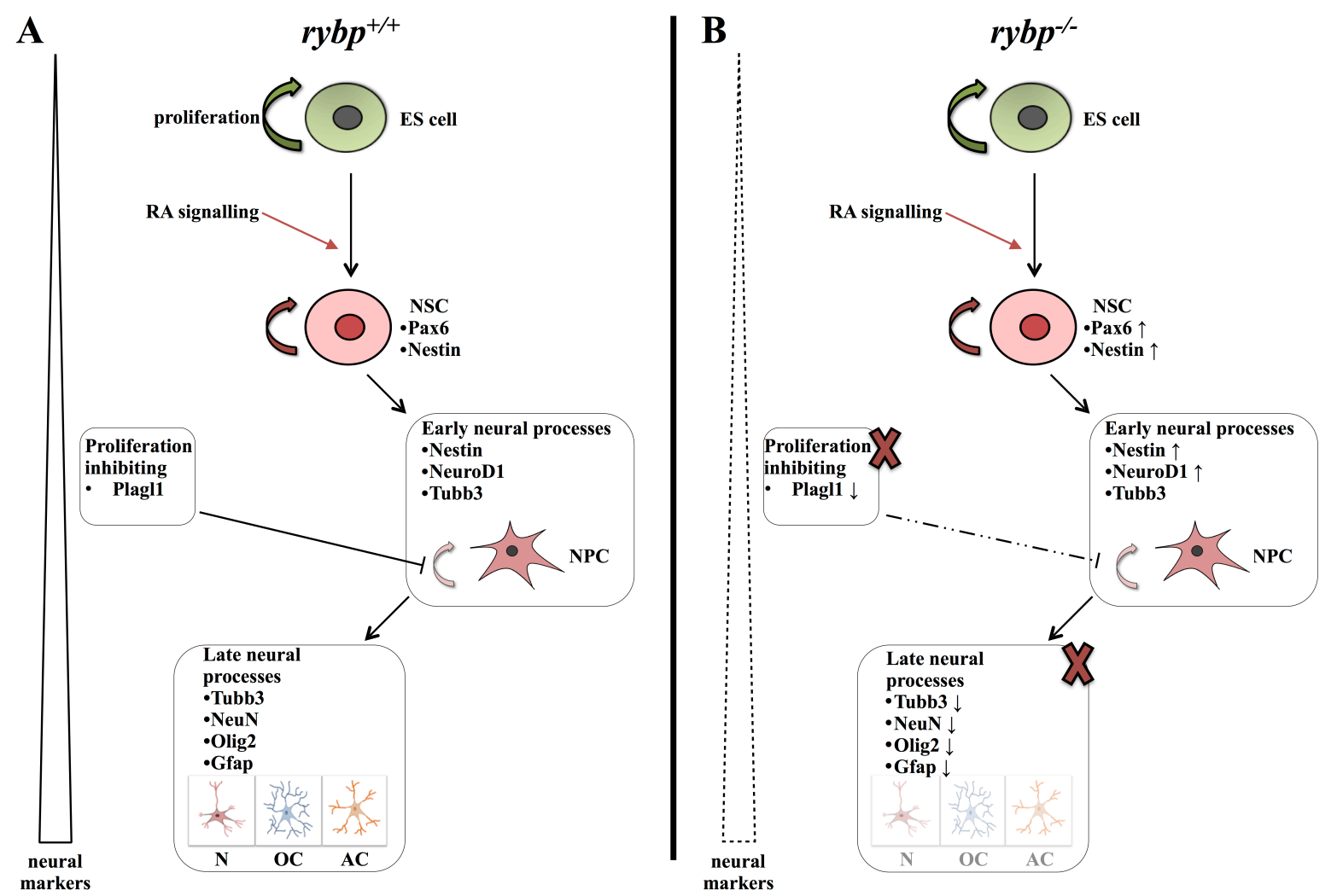

Figure 22 - Model of in vitro neural differentiation of ES cells in presence and absence of Rybp

(A) Differentiation of wild type ES cells towards matured cell types of the CNS in the presence of Rybp.

Pluripotent ES cells express key pluripotency markers (e.g. Oct4, Nanog) in undifferentiated state, which are gradually decreasing through in vitro neural differentiation. Parallel with this, early neural markers (Pax6, Nestin, NeuroD1) are upregulated in NSCs, which will confer reduced proliferative and high differentiation capacity to the cells. On the other hand, in the presence of Rybp, upregulation of Plagll helps to facilitate late neural differentiation and inhibits cell proliferation, which will facilitate the generation of terminally differentiated neural 
cell types (N, OC, AC). By the progression of neural differentiation, NPCs will differentiate further and start to express markers of specialized neural cell types (Tubb3, NeuN, Olig2, Gfap).

(B) Differentiation of pluripotent ES cells towards matured cell types of the CNS is impaired in the absence of Rybp.

During neural differentiation early neural markers (Pax6, Nestin) exhibit elevated expression level in the rybp null mutants. These will facilitate the generation of an expanded pool of NPCs with higher proliferative capacity. On the other hand, in the absence of Rybp, Plagll expression is defective, which also contributes to the increased proliferative and decreased differentiation capacity of the NPCs. As a result, the formation of terminally differentiated neural cell types $(N, O C, A C)$ will be impaired in the lack of functional Rybp.

Abbreviations: ES cell: embryonic stem cell, NSC: neural stem cell, NPC: neural progenitor cell, N: neuron, OC: oligodendrocyte, AC: astrocyte, RA: retinoic acid, CNS: central nervous system.

\subsection{Plagl1 is a downstream target of Rybp}

The other gene whose expression is drastically changed in the $r y b p^{-/-}$neural cultures is Plagl1, which is an important regulator of neural development (Valente and Auladell, 2001), apoptosis and cell-cycle arrest whereas it has antiproliferative and tumor suppressor activity (Abdollahi et al., 1997; Spengler et al., 1997). We found that Plagl1 is absent both in $r y b p^{-/-}$cardiac (Ujhelly et al., 2015) and neural cultures (Kovacs et al., 2016) which suggests that this deficiency is not cell-lineage specific. The observation that Plagl1 is completely downregulated in the absence of functional Rybp and the fact that Rybp and Plagll deficient mice exhibit similar developmental defects indicates a possible genetic or biochemical link between Rybp and Plagl1 (Chung et al., 2011; Pirity et al., 2005; Yuasa et al., 2010). Furthermore, Farhy et al. reported that Plagl1 is downregulated in the Pax6 deficient cells (Farhy et al., 2013). In this study increased level of Pax6 accompanied by the downregulation Plagl1 in Rybp deficient cells. In the absence of functional Rybp it is very likely that the balance of early and late neural processes is "unbalanced", which is probably linked to the upregulation of Pax6 and the loss of Plagl1 (Figure 22). This study is pinpointing a possible connection among a transcriptional 
circuit of Rybp, Plag1 and Pax6.

It is also known that Plagl1 promotes cell-cycle withdrawal of NPCs during the differentiation processes (Valente and Auladell, 2001). The tight regulation of cell-cycle is required to ensure timely generation and correct amount of the various neural cell types, which largely depends on the presence of Plagl1. We did not observe differences in the distribution of cell-cycle phases through the course of neural differentiation between $r y b p^{+/+}$and $r y b p^{-/-}$cells suggesting that Rybp may exert its function via a cell-cycle independent manner. Besides cell-cycle, apoptosis also contributes to establishing the complexity of CNS and helps to eliminate the excessive cells (Brill et al., 1999; Zakeri and Lockshin, 2002). During neural differentiation Plagll also mediates apoptosis independently of its cell-cycle arresting function (Spengler et al., 1997). In differentiating $r y b p^{-/-}$cells we found an increased rate of apoptosis compared to the wild type. At $\mathrm{d} 7$ and d10, when the rate of apoptosis is elevated in the mutant, the formation of NSCs is also extended compared to the wild type cultures. It is possible that a portion of the cells undergo apoptosis instead of differentiating into mature neural cell types and this may be resulted from the absence of Plagl1 and Rybp.

Results from luciferase reporter assay revealed that Rybp can activate the Plagll promoter. The promoter of Plagll contains three E2f binding sites, which are together with Yy1 sites may well serve as anchoring sites for an Rybp mediated transcriptional regulation process (Figure 23). This leaves open the possibility that Rybp regulates Plagll via an E2f dependent mechanism.

\subsection{Rybp may exert its biological functions via biochemically heterogenic multimeric complexes}

Possibilities for action of Rybp are likely very diverse. Recent studies showed that Rybp is a member of the recently identified ncPRC1 complex (Figure 23) (Chen and Dent, 2014; Farcas et al., 2012; He et al., 2013; Oliviero et al., 2015; Schwartz and Pirrotta, 2013; Turner and Bracken, 2013). Previous studies highlighted the importance of PRC members in neural development. Loss of Ring $1 \mathrm{~b}$, which is a core member of the ncPRC1 and binding partner of Rybp (Figure 23), caused premature neural differentiation (Román-Trufero et al., 2009). PRC1.1 complex member Kdm2b (Lysine (K)-specific demethylase 2b; also known as Fbx110 (F-box and leucine-rich repeat protein 10)) has essential function during embryonic 
development (Gearhart et al., 2006). Notably, loss of $\mathrm{Kdm} 2 \mathrm{~b}$ is perinatally lethal with incomplete neural tube closure, exencephaly, and altered cell-cycle processes in NPCs (Fukuda et al., 2011) partially mimicking the phenotype of the heterozygous rybp mice (Pirity et al., 2005). PRC1.4 member Pcgf4 (Polycomb group ring finger 4, also known as Bmil (B lymphoma Mo-MLV insertion region 1 homolog)) has important role in neural development since bmil mutant mice showed neurological defects (Van Der Lugt et al., 1994).

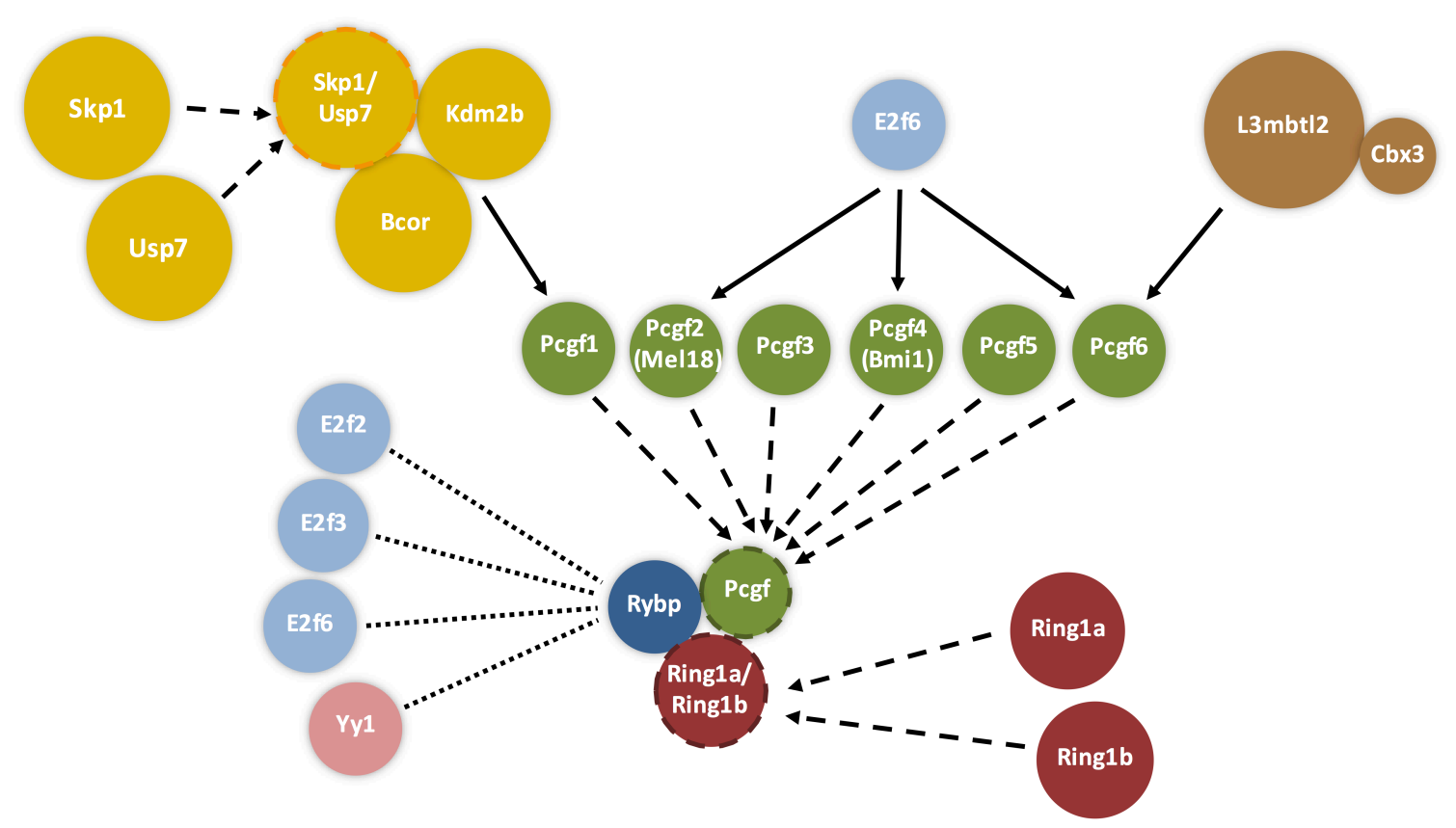

Figure 23-Rybp is a member of the non-canonical PRC1 complexes

In all different ncPRC1 complexes Rybp binds a Ring protein (Ringla or Ring1b) and a Pcgf protein. PRC1.1 complex encompasses Pcgf1, Bcor, Skpl or Usp7, and Kdm2b. In PRC1.2 complex Rybp and Ringla/Ringlb bind Pcgf2 (Mel18) and E2f6. In PRC1.4 complex Rybp and Ringla/Ringlb bind Pcgf4 (Bmil) and E2f6. PRC1.6 encompasses Pcgf6, E2f6, Cbx3 and L3mbtl2. E2f2, E2f3, E2f6 and Yyil can interact with Rybp.

Other PRC members and interactors are also important for neural development: complete lack of Yy1, binding partner of Rybp, is manifested in embryonic lethality, while heterozygote embryos exhibit neurulation defects (Donohoe et al., 1999); and the jmj null mutants show neural tube closure defect (Takeuchi et al., 1995). Ezh2, a core member of the PRC2, is highly 
expressed in NPCs and is downregulated through the differentiation of mature cortical neurons (Sparmann et al., 2013). Notably, Neurogenin 1, has been found to be suppressed by a PRC mediated mechanism at the neuronal-to-astrocytic transition of NPC differentiation during corticogenesis (Testa, 2011).

In our experimental system, the expression level of PRC1 and PRC2 members does not show great alteration during in vitro neural differentiation. We do not necessary expect compositional or gene expression changes at the PRC members since withdrawing one member does not necessary have effect on the whole complex, however it is possible that these complexes cannot function properly when Rybp is absent. Nevertheless, we cannot exclude the possibility that Rybp is functioning as a member of other multimeric complexes during different steps of neural development, so it is possible that the function of Rybp during neural differentiation is not PRC mediated. We assume that Rybp, independently from its polycomb function, can activate Plagl1. To our knowledge, Rybp has never been described previously as an activator. To clarify whether Rybp is functioning as member of PRCs or other multimeric protein complexes during neural development is a debate of further studies. 


\section{SUMMARY}

In current thesis I have investigated the function of the non-canonical PRC1 member, Rybp during neural lineage commitment. For this purpose, we utilized wild type and rybp null mutant ES cells and differentiated them in vitro into neural lineages. Our results showed that the formation of NSCs and NPCs was excessive in the rybp null mutant compared to the wild type, however they cannot form matured neural cell types properly. The absence of Rybp caused alteration in expression of key neural markers (Nestin, Tubb3, Gfap, Map2, Tau) and transcription factors (Sox2, Pax6, NeuroD1, NeuN, Olig2, Plag11). The endogenous Plag11 is one of the most downregulated genes suggesting a possible transcription circuit between Rybp, Plagl1 and other transcriptional factors. This study demonstrates the importance of Rybp in in vitro neural lineage specification. 


\section{REFERENCES}

Abdollahi, A., Roberts, D., Godwin, A.K., Schultz, D.C., Sonoda, G., Testa, J.R., Hamilton, T.C., 1997. Identification of a zinc-finger gene at 6q25: a chromosomal region implicated in development of many solid tumors. Oncogene 14, 1973-9. doi:10.1038/sj.onc. 1201034

Bain, G., Kitchens, D., Yao, M., Huettner, J.E., Gottlieb, D.I., 1995. Embryonic stem cells express neuronal properties in vitro. Dev. Biol. 168, 342-57. doi:10.1006/dbio.1995.1085

Bel-Vialar, S., Medevielle, F., Pituello, F., 2007. The on/off of Pax6 controls the tempo of neuronal differentiation in the developing spinal cord. Dev. Biol. 305, 659-73. doi:10.1016/j.ydbio.2007.02.012

Bergquist, H., 1964. The formation of the front part of the neural tube. Experientia 20, 92-93. doi:10.1007/BF02151260

Bibel, M., Richter, J., Schrenk, K., Tucker, K.L., Staiger, V., Korte, M., Goetz, M., Barde, Y.A., 2004. Differentiation of mouse embryonic stem cells into a defined neuronal lineage. Nat. Neurosci. 7, 1003-9. doi:10.1038/nn1301

Bignami, A., Eng, L.F., Dahl, D., Uyeda, C.T., 1972. Localization of the glial fibrillary acidic protein in astrocytes by immunofluorescence. Brain Res. 43, 429-435. doi:10.1016/0006-8993(72)90398-8

Black, M.M., Cochran, J.M., Kurdyla, J.T., 1984. Solubility properties of neuronal tubulin: evidence for labile and stable microtubules. Brain Res. 295, 255-63.

Blum, M., Gaunt, S.J., Cho, K.W.Y., Steinbeisser, H., Blumberg, B., Bittner, D., De Robertis, E.M., 1992. Gastrulation in the mouse: The role of the homeobox gene goosecoid. Cell 69, 1097-1106. doi:10.1016/0092-8674(92)90632-M

Boutin, C., Hardt, O., de Chevigny, A., Coré, N., Goebbels, S., Seidenfaden, R., Bosio, A., Cremer, H., 2010. NeuroD1 induces terminal neuronal differentiation in olfactory neurogenesis. Proc. Natl. Acad. Sci. U. S. A. 107, 1201-6. doi:10.1073/pnas.0909015107

Boyer, L. a, Plath, K., Zeitlinger, J., Brambrink, T., Medeiros, L. a, Lee, T.I., Levine, S.S., Wernig, M., Tajonar, A., Ray, M.K., Bell, G.W., Otte, A.P., Vidal, M., Gifford, D.K., Young, R. a, Jaenisch, R., 2006. Polycomb complexes repress developmental regulators in murine embryonic stem cells. Nature 441, 349-353. doi:10.1038/nature04733

Brill, A., Torchinsky, A., Carp, H., Toder, V., 1999. The role of apoptosis in normal and abnormal embryonic development. J. Assist. Reprod. Genet. 16, 512-9. doi:10.1023/A:1020541019347

Caceres, A., Banker, G., Steward, O., Binder, L., Payne, M., 1984. MAP2 is localized to the dendrites of hippocampal neurons which develop in culture. Dev. Brain Res. 13, 314318. doi:10.1016/0165-3806(84)90167-6

Chen, D., Zhang, J., Li, M., Rayburn, E.R., Wang, H., Zhang, R., 2009. RYBP stabilizes p53 by modulating MDM2. EMBO Rep. 10, 166-72. doi:10.1038/embor.2008.231

Chen, T., Dent, S.Y.R., 2014. Chromatin modifiers and remodellers: regulators of cellular differentiation. Nat. Rev. Genet. 15, 93-106. doi:10.1038/nrg3607

Chung, S.-H., Marzban, H., Aldinger, K., Dixit, R., Millen, K., Schuurmans, C., Hawkes, R., 
2011. Zac1 plays a key role in the development of specific neuronal subsets in the mouse cerebellum. Neural Dev. 6, 25. doi:10.1186/1749-8104-6-25

Donohoe, M.E., Zhang, X., McGinnis, L., Biggers, J., Li, E., Shi, Y., 1999. Targeted disruption of mouse Yin Yang 1 transcription factor results in peri-implantation lethality. Mol. Cell. Biol. 19, 7237-7244.

Eiraku, M., Watanabe, K., Matsuo-Takasaki, M., Kawada, M., Yonemura, S., Matsumura, M., Wataya, T., Nishiyama, A., Muguruma, K., Sasai, Y., 2008. Self-Organized Formation of Polarized Cortical Tissues from ESCs and Its Active Manipulation by Extrinsic??Signals. Cell Stem Cell 3, 519-532. doi:10.1016/j.stem.2008.09.002

Eng, L.F., Vanderhaeghen, J.J., Bignami, A., Gerstl, B., 1971. An acidic protein isolated from fibrous astrocytes. Brain Res. 28, 351-354. doi:10.1016/0006-8993(71)90668-8

Ericson, J., Rashbass, P., Schedl, A., Brenner-Morton, S., Kawakami, A., van Heyningen, V., Jessell, T.M., Briscoe, J., 1997. Pax6 controls progenitor cell identity and neuronal fate in response to graded Shh signaling. Cell 90, 169-80.

Fanarraga, M., Avila, J., Zabala, J., 1999. Expression of unphosphorylated class III betatubulin isotype in neuroepithelial cells demonstrates neuroblast commitment and differentiation. Eur. J. Neurosci. 11, 516-527.

Farcas, A.M., Blackledge, N.P., Sudbery, I., Long, H.K., McGouran, J.F., Rose, N.R., Lee, S., Sims, D., Cerase, A., Sheahan, T.W., Koseki, H., Brockdorff, N., Ponting, C.P., Kessler, B.M., Klose, R.J., 2012. KDM2B links the polycomb repressive complex 1 (PRC1) to recognition of CpG islands. Elife 2012. doi:10.7554/eLife.00205

Farhy, C., Elgart, M., Shapira, Z., Oron-Karni, V., Yaron, O., Menuchin, Y., Rechavi, G., Ashery-Padan, R., 2013. Pax6 is required for normal cell-cycle exit and the differentiation kinetics of retinal progenitor cells. PLoS One 8, e76489. doi:10.1371/journal.pone.0076489

Ferreira, A., Caceres, A., 1992. Expression of the class III beta-tubulin isotype in developing neurons in culture. J. Neurosci. Res. 32, 516-29. doi:10.1002/jnr.490320407

Fukuda, T., Tokunaga, A., Sakamoto, R., Yoshida, N., 2011. Fbx110/Kdm2b deficiency accelerates neural progenitor cell death and leads to exencephaly. Mol. Cell. Neurosci. 46, 614-24. doi:10.1016/j.mcn.2011.01.001

Gage, F.H., 2000. Mammalian Neural Stem Cells. Science (80-. ). 287, 1433-1438. doi:10.1126/science.287.5457.1433

Gajović, S., St-Onge, L., Yokota, Y., Gruss, P., 1997. Retinoic acid mediates Pax6 expression during in vitro differentiation of embryonic stem cells. Differentiation. 62, 187-92.

Gao, Z., Zhang, J., Bonasio, R., Strino, F., Sawai, A., Parisi, F., Kluger, Y., Reinberg, D., 2012. PCGF homologs, CBX proteins, and RYBP define functionally distinct PRC1 family complexes. Mol. Cell 45, 344-56. doi:10.1016/j.molcel.2012.01.002

García, E., Marcos-Gutiérrez, C., del Mar Lorente, M., Moreno, J.C., Vidal, M., 1999. RYBP, a new repressor protein that interacts with components of the mammalian Polycomb complex, and with the transcription factor YY1. EMBO J. 18, 3404-18. doi:10.1093/emboj/18.12.3404

Gearhart, M.D., Corcoran, C.M., Wamstad, J.A., Bardwell, V.J., 2006. Polycomb group and SCF ubiquitin ligases are found in a novel BCOR complex that is recruited to BCL6 targets. Mol. Cell. Biol. 26, 6880-9. doi:10.1128/MCB.00630-06

Graham, V., Khudyakov, J., Ellis, P., Pevny, L., 2003. SOX2 functions to maintain neural progenitor identity. Neuron 39, 749-765. doi:10.1016/S0896-6273(03)00497-5

Haub, O., Goldfarb, M., 1991. Expression of the fibroblast growth factor-5 gene in the mouse 
embryo. Development 112, 397-406.

He, J., Shen, L., Wan, M., Taranova, O., Wu, H., Zhang, Y., 2013. Kdm2b maintains murine embryonic stem cell status by recruiting PRC1 complex to $\mathrm{CpG}$ islands of developmental genes. Nat. Cell Biol. 15, 373-84. doi:10.1038/ncb2702

He, S., Pirity, M.K., Wang, W.-L., Wolf, L., Chauhan, B.K., Cveklova, K., Tamm, E.R., Ashery-Padan, R., Metzger, D., Nakai, A., Chambon, P., Zavadil, J., Cvekl, A., 2010. Chromatin remodeling enzyme Brg1 is required for mouse lens fiber cell terminal differentiation and its denucleation. Epigenetics Chromatin 3, 21. doi:10.1186/17568935-3-21

Hébert, J.M., Boyle, M., Martin, G.R., 1991. mRNA localization studies suggest that murine FGF-5 plays a role in gastrulation. Development 112, 407-415.

Hemmer, K., Zhang, M., van Wullen, T., Sakalem, M., Tapia, N., Baumuratov, A., Kaltschmidt, C., Kaltschmidt, B., Scholer, H.R., Zhang, W., Schwamborn, J.C., 2014. Induced neural stem cells achieve long-term survival and functional integration in the adult mouse brain. Stem Cell Reports 3, 423-431. doi:10.1016/j.stemcr.2014.06.017

Kanai-Azuma, M., Kanai, Y., Gad, J.M., Tajima, Y., Taya, C., Kurohmaru, M., Sanai, Y., Yonekawa, H., Yazaki, K., Tam, P.P.L., Hayashi, Y., 2002. Depletion of definitive gut endoderm in Sox17-null mutant mice. Development 129, 2367-79.

Kaneko, T., Miyagishima, H., Hasegawa, T., Mizutani-Koseki, Y., Isono, K., Koseki, H., 2003. The mouse YAF2 gene generates two distinct transcripts and is expressed in preand postimplantation embryos. Gene 315, 183-92.

Kawasaki, H., Mizuseki, K., Nishikawa, S., Kaneko, S., Kuwana, Y., Nakanishi, S., Nishikawa, S.-I., Sasai, Y., 2000. Induction of Midbrain Dopaminergic Neurons from ES Cells by Stromal Cell-Derived Inducing Activity. Neuron 28, 31-40. doi:10.1016/S0896-6273(00)00083-0

Kingston, R.E., Chen, C.A., Rose, J.K., 2003. Calcium phosphate transfection. Curr. Protoc. Mol. Biol. Chapter 9, Unit 9.1. doi:10.1002/0471142727.mb0901s63

Kosik, K.S., Joachim, C.L., Selkoe, D.J., 1986. Microtubule-associated protein tau (tau) is a major antigenic component of paired helical filaments in Alzheimer disease. Proc. Natl. Acad. Sci. U. S. A. 83, 4044-4048. doi:10.1097/00002093-198701030-00022

Kovacs, G., Szabo, V., Pirity, M.K., 2016. Absence of Rybp Compromises Neural Differentiation of Embryonic Stem Cells 2016.

Lancaster, M.A., Renner, M., Martin, C.-A., Wenzel, D., Bicknell, L.S., Hurles, M.E., Homfray, T., Penninger, J.M., Jackson, A.P., Knoblich, J.A., 2013. Cerebral organoids model human brain development and microcephaly. Nature 501, 373-9. doi:10.1038/nature12517

Lendahl, U., Zimmerman, L.B., McKay, R.D., 1990. CNS stem cells express a new class of intermediate filament protein. Cell 60, 585-95.

Li, G., Warden, C., Zou, Z., Neman, J., Krueger, J.S., Jain, A., Jandial, R., Chen, M., 2013. Altered expression of polycomb group genes in glioblastoma multiforme. PLoS One 8. doi:10.1371/journal.pone.0080970

Lu, B., Jan, L., Jan, Y.N., 2000. Control of cell divisions in the nervous system: symmetry and asymmetry. Annu. Rev. Neurosci. 23, 531-56. doi:10.1146/annurev.neuro.23.1.531

Ma, L., Cantrup, R., Varrault, A., Colak, D., Klenin, N., Götz, M., McFarlane, S., Journot, L., Schuurmans, C., 2007. Zac1 functions through TGFbetaII to negatively regulate cell number in the developing retina. Neural Dev. 2, 11. doi:10.1186/1749-8104-2-11

Magin, T.M., McWhir, J., Melton, D.W., 1992. A new mouse embryonic stem cell line with 
good germ line contribution and gene targeting frequency. Nucleic Acids Res. 20, 37956.

Matsushima, D., Heavner, W., Pevny, L.H., 2011. Combinatorial regulation of optic cup progenitor cell fate by SOX2 and PAX6. Development 138, 443-454. doi:10.1242/dev.055178

Mizuguchi, R., Sugimori, M., Takebayashi, H., Kosako, H., Nagao, M., Yoshida, S., Nabeshima, Y., Shimamura, K., Nakafuku, M., 2001. Combinatorial roles of olig2 and neurogenin 2 in the coordinated induction of pan-neuronal and subtype-specific properties of motoneurons. Neuron 31, 757-71.

Mullen, R.J., Buck, C.R., Smith, A.M., 1992. NeuN, a neuronal specific nuclear protein in vertebrates. Development 116, 201-211. doi:VL - 116

Nagy, A., Rossant, J., Nagy, R., Abramow-Newerly, W., Roder, J.C., 1993. Derivation of completely cell culture-derived mice from early-passage embryonic stem cells. Proc. Natl. Acad. Sci. U. S. A. 90, 8424-8.

Nasu, M., Takata, N., Danjo, T., Sakaguchi, H., Kadoshima, T., Futaki, S., Sekiguchi, K., Eiraku, M., Sasai, Y., 2012. Robust Formation and Maintenance of Continuous Stratified Cortical Neuroepithelium by Laminin-Containing Matrix in Mouse ES Cell Culture. PLoS One 7. doi:10.1371/journal.pone.0053024

Novak, R.L., Phillips, a C., 2008. Adenoviral-mediated Rybp expression promotes tumor cell-specific apoptosis. Cancer Gene Ther. 15, 713-22. doi:10.1038/cgt.2008.25

Okabe, S., Forsberg-Nilsson, K., Spiro, A.C., Segal, M., McKay, R.D.G., 1996. Development of neuronal precursor cells and functional postmitotic neurons from embryonic stem cells in vitro. Mech. Dev. 59, 89-102. doi:10.1016/0925-4773(96)00572-2

Oliviero, G., Munawar, N., Watson, A., Streubel, G., Manning, G., Bardwell, V., Bracken, A.P., Cagney, G., 2015. The variant Polycomb Repressor Complex 1 component PCGF1 interacts with a pluripotency sub-network that includes DPPA4, a regulator of embryogenesis. Sci. Rep. 5, 18388. doi:10.1038/srep18388

Paglini, G., Peris, L., Mascotti, F., Quiroga, S., Caceres, A., 2000. Tau protein function in axonal formation. Neurochem. Res. 25, 37-42. doi:10.1023/A:1007531230651

Park, D., Xiang, A.P., Mao, F.F., Zhang, L., Di, C.-G., Liu, X.-M., Shao, Y., Ma, B.-F., Lee, J.-H., Ha, K.-S., Walton, N., Lahn, B.T., 2010. Nestin is required for the proper selfrenewal of neural stem cells. Stem Cells 28, 2162-71. doi:10.1002/stem.541

Pirity, M.K., Locker, J., Schreiber-Agus, N., 2005. Rybp/DEDAF is required for early postimplantation and for central nervous system development. Mol. Cell. Biol. 25, 7193202. doi:10.1128/MCB.25.16.7193-7202.2005

Pirity, M.K., Wang, W.-L., Wolf, L. V, Tamm, E.R., Schreiber-Agus, N., Cvekl, A., 2007. Rybp, a polycomb complex-associated protein, is required for mouse eye development. BMC Dev. Biol. 7, 39. doi:10.1186/1471-213X-7-39

Román-Trufero, M., Méndez-Gómez, H.R., Pérez, C., Hijikata, A., Fujimura, Y., Endo, T., Koseki, H., Vicario-Abejón, C., Vidal, M., 2009. Maintenance of undifferentiated state and self-renewal of embryonic neural stem cells by Polycomb protein Ring1B. Stem Cells 27, 1559-70. doi:10.1002/stem.82

Sawa, C., Yoshikawa, T., Matsuda-Suzuki, F., Deléhouzée, S., Goto, M., Watanabe, H., Sawada, J., Kataoka, K., Handa, H., 2002. YEAF1/RYBP and YAF-2 are functionally distinct members of a cofactor family for the YY1 and E4TF1/hGABP transcription factors. J. Biol. Chem. 277, 22484-90. doi:10.1074/jbc.M203060200

Schlisio, S., Halperin, T., Vidal, M., Nevins, J.R., 2002. Interaction of YY1 with E2Fs, 
mediated by RYBP, provides a mechanism for specificity of E2F function. EMBO J. 21, 5775-86.

Schwartz, Y.B., Pirrotta, V., 2013. A new world of Polycombs: unexpected partnerships and emerging functions. Nat. Rev. Genet. 14, 853-64. doi:10.1038/nrg3603

Simon, J.A., Kingston, R.E., 2013. Occupying Chromatin: Polycomb Mechanisms for Getting to Genomic Targets, Stopping Transcriptional Traffic, and Staying Put. Mol. Cell 49, 808-24. doi:10.1016/j.molcel.2013.02.013

Sparmann, A., Xie, Y., Verhoeven, E., Vermeulen, M., Lancini, C., Gargiulo, G., Hulsman, D., Mann, M., Knoblich, J.A., van Lohuizen, M., 2013. The chromodomain helicase Chd4 is required for Polycomb-mediated inhibition of astroglial differentiation. EMBO J. 32, 1598-612. doi:10.1038/emboj.2013.93

Spengler, D., Villalba, M., Hoffmann, A., Pantaloni, C., Houssami, S., Bockaert, J., Journot, L., 1997. Regulation of apoptosis and cell cycle arrest by Zac1, a novel zinc finger protein expressed in the pituitary gland and the brain. EMBO J. 16, 2814-25. doi:10.1093/emboj/16.10.2814

Stanton, S.E., Blanck, J.K., Locker, J., Schreiber-Agus, N., 2007. Rybp interacts with Hippi and enhances Hippi-mediated apoptosis. Apoptosis 12, 2197-2206. doi:10.1007/s10495007-0131-3

Takebayashi, H., Nabeshima, Y., Yoshida, S., Chisaka, O., Ikenaka, K., Nabeshima, Y., 2002. The basic helix-loop-helix factor olig2 is essential for the development of motoneuron and oligodendrocyte lineages. Curr. Biol. 12, 1157-63.

Takeuchi, T., Yamazaki, Y., Katoh-Fukui, Y., Tsuchiya, R., Kondo, S., Motoyama, J., Higashinakagawa, T., 1995. Gene trap capture of a novel mouse gene, jumonji, required for neural tube formation. Genes Dev. 9, 1211-1222. doi:10.1101/gad.9.10.1211

Taranova, O. V., Magness, S.T., Fagan, B.M., Wu, Y., Surzenko, N., Hutton, S.R., Pevny, L.H., 2006. SOX2 is a dose-dependent regulator of retinal neural progenitor competence. Genes Dev. 20, 1187-1202. doi:10.1101/gad.1407906

Tavares, L., Dimitrova, E., Oxley, D., Webster, J., Poot, R., Demmers, J., Bezstarosti, K., Taylor, S., Ura, H., Koide, H., Wutz, A., Vidal, M., Elderkin, S., Brockdorff, N., 2012. RYBP-PRC1 complexes mediate $\mathrm{H} 2 \mathrm{~A}$ ubiquitylation at polycomb target sites independently of PRC2 and H3K27me3. Cell 148, 664-78. doi:10.1016/j.cell.2011.12.029

Taylor, B.S., Schultz, N., Hieronymus, H., Gopalan, A., Xiao, Y., Carver, B.S., Arora, V.K., Kaushik, P., Cerami, E., Reva, B., Antipin, Y., Mitsiades, N., Landers, T., Dolgalev, I., Major, J.E., Wilson, M., Socci, N.D., Lash, A.E., Heguy, A., Eastham, J.A., Scher, H.I., Reuter, V.E., Scardino, P.T., Sander, C., Sawyers, C.L., Gerald, W.L., 2010. Integrative Genomic Profiling of Human Prostate Cancer. Cancer Cell 18, 11-22. doi:10.1016/j.ccr.2010.05.026

Testa, G., 2011. The time of timing: how Polycomb proteins regulate neurogenesis. Bioessays 33, 519-28. doi:10.1002/bies.201100021

Thomson, M., Liu, S.J., Zou, L.N., Smith, Z., Meissner, A., Ramanathan, S., 2011. Pluripotency factors in embryonic stem cells regulate differentiation into germ layers. Cell 145, 875-889. doi:10.1016/j.cell.2011.05.017

Trapnell, C., Pachter, L., Salzberg, S.L., 2009. TopHat: Discovering splice junctions with RNA-Seq. Bioinformatics 25, 1105-1111. doi:10.1093/bioinformatics/btp120

Trimarchi, J.M., Fairchild, B., Wen, J., Lees, J.A., 2001. The E2F6 transcription factor is a component of the mammalian Bmil-containing polycomb complex. Proc. Natl. Acad. 
Sci. U. S. A. 98, 1519-24. doi:10.1073/pnas.041597698

Tropepe, V., Hitoshi, S., Sirard, C., Mak, T.W., Rossant, J., Van Der Kooy, D., 2001. Direct neural fate specification from embryonic stem cells: A primitive mammalian neural stem cell stage acquired through a default mechanism. Neuron 30, 65-78. doi:10.1016/S08966273(01)00263-X

Turner, S.A., Bracken, A.P., 2013. A "complex" issue: Deciphering the role of variant PRC1 in ESCs. Cell Stem Cell. doi:10.1016/j.stem.2013.01.014

Ujhelly, O., Szabo, V., Kovacs, G., Vajda, F., Mallok, S., Prorok, J., Acsai, K., Hegedus, Z., Krebs, S., Dinnyes, A., Pirity, M.K., 2015. Lack of Rybp in Mouse Embryonic Stem Cells Impairs Cardiac Differentiation. Stem Cells Dev. 24, 2193-205. doi: $10.1089 / \mathrm{scd} .2014 .0569$

Valente, T., Auladell, C., 2001. Expression pattern of Zac1 mouse gene, a new zinc-finger protein that regulates apoptosis and cellular cycle arrest, in both adult brain and along development. Mech. Dev. 108, 207-11.

Valente, T., Junyent, F., Auladell, C., 2005. Zac1 is expressed in progenitor/stem cells of the neuroectoderm and mesoderm during embryogenesis: differential phenotype of the Zac1expressing cells during development. Dev. Dyn. 233, 667-79. doi:10.1002/dvdy.20373

Van Der Lugt, N.M.T., Domen, J., Linders, K., Van Roon, M., Robanus-Maandag, E., Te Riele, H., Van Der Valk, M., Deschamps, J., Sofroniew, M., Van Lohuizen, M., Berns, A., 1994. Posterior transformation, neurological abnormalities, and severe hematopoietic defects in mice with a targeted deletion of the bmi-1 proto-oncogene. Genes Dev. 8 , 757-769. doi:10.1101/gad.8.7.757

Varrault, A., Gueydan, C., Delalbre, A., Bellmann, A., Houssami, S., Aknin, C., Severac, D., Chotard, L., Kahli, M., Le Digarcher, A., Pavlidis, P., Journot, L., 2006. Zac1 Regulates an Imprinted Gene Network Critically Involved in the Control of Embryonic Growth. Dev. Cell 11, 711-722. doi:10.1016/j.devcel.2006.09.003

Voruganti, S., Xu, F., Qin, J.-J., Guo, Y., Sarkar, S., Gao, M., Zheng, Z., Wang, M.-H., Zhou, J., Qian, B., Zhang, R., Wang, W., 2015. RYBP predicts survival of patients with nonsmall cell lung cancer and regulates tumor cell growth and the response to chemotherapy. Cancer Lett. 369, 386-395. doi:10.1016/j.canlet.2015.09.003

Wamstad, J.A., Corcoran, C.M., Keating, A.M., Bardwell, V.J., 2008. Role of the transcriptional corepressor Bcor in embryonic stem cell differentiation and early embryonic development. PLoS One 3, e2814. doi:10.1371/journal.pone.0002814

Wang, W., Cheng, J., Qin, J.-J., Voruganti, S., Nag, S., Fan, J., Gao, Q., Zhang, R., 2014. RYBP expression is associated with better survival of patients with hepatocellular carcinoma (HCC) and responsiveness to chemotherapy of HCC cells in vitro and in vivo. Oncotarget 5, 11604-19.

Wernig, M., Benninger, F., Schmandt, T., Rade, M., Tucker, K.L., Büssow, H., Beck, H., Brüstle, O., 2004. Functional integration of embryonic stem cell-derived neurons in vivo. J. Neurosci. 24, 5258-5268. doi:10.1523/JNEUROSCI.0428-04.200

Wigler, M., Sweet, R., Sim, G.K., Wold, B., Pellicer, A., Lacy, E., Maniatis, T., Silverstein, S., Axel, R., 1979. Transformation of mammalian cells with genes from procaryotes and eucaryotes. Cell 16, 777-785. doi:10.1016/0092-8674(79)90093-X

Yuasa, S., Onizuka, T., Shimoji, K., Ohno, Y., Kageyama, T., Yoon, S.H., Egashira, T., Seki, T., Hashimoto, H., Nishiyama, T., Kaneda, R., Murata, M., Hattori, F., Makino, S., Sano, M., Ogawa, S., Prall, O.W.J., Harvey, R.P., Fukuda, K., 2010. Zac1 is an essential transcription factor for cardiac morphogenesis. Circ. Res. 106, 1083-91. 
doi:10.1161/CIRCRESAHA.109.214130

Zakeri, Z., Lockshin, R.A., 2002. Cell death during development. J. Immunol. Methods 265, 3-20. doi:10.1016/S0022-1759(02)00067-4

Zeng, L.-H., Wang, S.-Q., Deng, H., Zhang, Y.-P., Ying, Y., Chen, X.-W., Xu, S.-L., Lin, X.M., 2015. [Effect of RYBP Gene Silencing on Sensitivity of HL-60 Cells to Chemotherapeutic Drugs]. Zhongguo Shi Yan Xue Ye Xue Za Zhi 23, 1576-81.

Zhao, J.-L., Huang, F., He, F., Gao, C.-C., Liang, S.-Q., Ma, P.-F., Dong, G.-Y., Han, H., Qin, H.-Y., 2016. Forced Activation of Notch in Macrophages Represses Tumor Growth by Upregulating miR-125a and Disabling Tumor-Associated Macrophages. Cancer Res. 0008-5472.CAN-15-2019-. doi:10.1158/0008-5472.CAN-15-2019

Zheng, L., Schickling, O., Peter, M.E., Lenardo, M.J., 2001. The Death Effector Domainassociated Factor Plays Distinct Regulatory Roles in the Nucleus and Cytoplasm. J. Biol. Chem. 276, 31945-52. doi:10.1074/jbc.M102799200

Zhou, Q., Wang, S., Anderson, D.J., 2000. Identification of a novel family of oligodendrocyte lineage-specific basic helix-loop-helix transcription factors. Neuron 25, 331-43. 


\section{ACKNOWLEDGEMENTS}

I am especially grateful to my supervisor Dr. Melinda K. Pirity, for giving me the opportunity to work in her laboratory, her kind support and her essential guidance for my work. She showed me how to think like a scientist. Without her supervising this work would not be fulfilled.

I warmly thank my colleagues Viktória Szabó, Enikő Sutus, Surya Henry for the technical help and support. I am very grateful to my former colleague Mária Dudás Radóné (also known as Gyugyi :-) ) for the initial help in the acquirement of laboratory technics.

I would also like to thank to Dr. Gabriella Endre, Dr. Tibor Németh and Dr. Attila Gácser for the helping in qRT-PCR experiments, for Dr. László Kozma-Bognár for helping in the luciferase activity measurement and for Dr. Zoltán Hegedüs for helping evaluate the genome wide profiling.

I would also like to thank Dr. Ilona Dusha for the critical reading of this thesis and gave me useful advices.

This work was carried out in the Laboratory of Embryonic and Induced Pluripotent Stem Cells, Institute of Genetics, Biological Research Center of the Hungarian Academy of Sciences (Szeged, Hungary). I would like to thank to Dr. Miklós Erdélyi for giving me the opportunity to carry on this study in his institute.

I owe sincere thankfulness to my friend, Dr. Ferenc Zádor, who have been my support over the years.

Last, but not least, I am very grateful to my family and my partner, Hedvig for the infinite patience and support. I love you all! 


\section{APPENDICES}

Appendix A: Summary of the $\mathrm{PhD}$ thesis in Hungarian

Appendix B: Unigene and Mouse Genome Informatics (MGI) ID numbers of examined markers

Appendix C: Tables from genome wide profiling

Appendix D: Off-prints of thesis related publications 
Appendix A: Summary of the $\mathrm{PhD}$ thesis in Hungarian 


\title{
A polikomb fehérje, Rybp kulcsfontosságú az egér embrionális őssejtek neurális differenciációjához
}

\author{
Ph.D. értekezés összefoglalója
}

\section{BEVEZETÉS}

\section{Őssejtek neurális differenciációja}

Az embrionális őssejtekből alakul ki egy felnőtt szervezet minden specializált sejttípusa és szövete. A központi idegrendszer kialakulása során, a korai szakaszban a pluripotens embrionális őssejtek először multipotens neurális őssejtekké, majd neurális progenitor sejtekké differenciálódnak. A neurális differenciáció késői szakaszában ezek a progenitorok érett neuronokká, asztrocitákká és oligodendrocitákká fejlődnek. Ezen folyamat több, összetett lépésből áll, melyek finoman szabályozottak és zavaruk könnyen idegrendszeri fejlődési rendellenességek kialakulásához vezethet. A neurális differenciáció folyamatának szabályozásában számos transzkripciós regulátor játszik döntő szerepet. Ezek közül a polikomb represszív komplexek jelentős szerepet játszanak a pluripotencia fenntartásában, ugyanakkor részt vesznek a differenciáció elindításában a specializációs faktorok repressziójának feloldásával. Tézisem, egy ilyen polikomb represszív komplex tagra, az Rybp-re (Ring1 and Yyl binding protein), valamint annak neurális specializációban betöltött szerepére fókuszál.

\section{Az Rybp esszenciális az embrionális fejlődéshez és a központi idegrendszer kialakulásához}

Csoportunk korábban megállapította, hogy az rybp homozigóta mutáns egerek beágyazódás kori letális fenotípust mutatnak, a heterozigótákban pedig az idegrendszer fejlődési rendellenességeket (velőcső záródási rendellenesség, exenkefália, stb) figyeltünk meg. Annak vizsgálata, hogy az Rybp fehérje teljes hiánya milyen hatással van az idegsejtek kialakulására, 
a homozigóta egyedek korai letalitása miatt in vivo nem lehetséges, így az Rybp neurális differenciációban betöltött szerepét in vitro vizsgáltuk tovább. Vizsgálataim alapját az őssejtek azon egyedülálló sajátsága adta, hogy megfelelö feltételek mellett, in vitro körülmények között is megtartják pluripotenciájukat és differenciációs képességüket. Az in vitro modellrendszer használatával így lehetőségünk nyílt arra, hogy megvizsgáljuk, az Rybp mely differenciációs folyamatokban játszik szerepet az idegi fejlődés során.

\section{CÉLKITÜZÉSEK}

Jelen tanulmány célja az Rybp idegi specializációban betöltött szerepének karakterizálása.

Munkánk során a következőkre fordítottunk kiemelt figyelmet:

- megvizsgáltuk, hogy az rybp homozigóta mutáns őssejtek képesek-e a fő idegi sejttípusokat (neuronok, oligodendrociták, asztrociták) kialakítani.

- leírtuk az rybp homozigóta mutáns őssejtekből differenciálódott neurális prekurzor sejtek jellegzetességeit, külön figyelmet fordítva a megújulási és differenciációs képességükre.

- meghatároztuk, hogy mely érett neurális formák képzése zavart az Rybp hiányában.

- célunk volt olyan géneket találni, melyek az Rybp „downstream” célgénjei és expressziójuk megváltozik az Rybp hiányában vagy jelenlétében a neurális differenciáció során.

\section{ALKALMAZOTT MÓDSZEREK}

\section{Össejtek in vitro neurális differenciációja}

Vad típusú $\left(r y b p^{+/+}\right)$és Rybp-t nem expresszáló, homozigóta mutáns ( $\left.r y b p^{-/}\right)$őssejtvonalak fenntartása zselatinnal felületkezelt sejttenyésztő csészében zajlott. A neurális differenciációt Bibel és csoportja, 2004-ben megjelent közleménye alapján végeztük, kisebb módosításokkal. 
Az őssejtekből szuszpenziós kultúrában három dimenziós aggregátumokat (úgynevezett “embrionális testecskék”) hoztunk létre, a negyedik napon retinsavval indukáltuk a neuroektoderma feldúsulását, majd az embrionális testecskék disszociációját követően, a sejteket azonos számban, felületkezelt sejttenyésztő edényekbe helyeztük. A letapasztott sejteket 6 napon keresztül tenyésztettük. További analízis céljából mintavétel történt a 0., 3., 7., 10. és 14 napokon.

\section{Morfológiai analízis}

A mintavételi időpontokban a differenciálódó sejtek morfológiai analízisét a következőképp végeztük: a paraformaldehiddel fixált őssejtekről (0.nap) és embrionális testekről (3. nap, 7. nap), valamint a kristály ibolyával festett, letapasztott neurális kultúrákról (10. nap, 14. nap) Olympus CellR mikroszkóppal készítettünk fénymikroszkópos képeket. A fixált embrionális testekről készült, hematoxilinnal és eozinnal festett szekciókat elemezve vizsgáltuk a bennük kialakuló struktúrákat.

\section{Molekuláris analízis}

A minták génexpressziós analízise kvantitatív valós idejü polimeráz láncreakció (qRT-PCR) segítségével történt. Ennek során pluripotencia faktorok, polikomb represszív komplex tagok, csíralemez markerek és neurális markerek relatív génexpresszióját vizsgáltuk a differenciáció során a két sejtvonalban. A fehérjekifejeződési mintázat analízisét immuncitokémia segítségével végeztük, melynek során neurális markerek fehérje szintű kifejeződését, illetve annak mintázatát tanulmányoztuk letapasztott neurális kultúrákban.

\section{Sejtciklus analízis és apoptózis szintjének mérése áramlási citometriával}

A feltüntetett időpontokban a sejteket bromodeoxiuridinnel kezeltük, majd a megfelelő előkészítés után propídium-jodiddal inkubáltuk. A differenciáció során a különböző sejtciklusokban tartózkodó, valamint az apoptózison átesett sejtek számát fluoreszcenciaaktivált áramlási citométer segítségével állapítottuk meg. 


\section{Luciferáz riporter assay}

COS7 sejtekbe $\mathrm{CaPO}_{4}$ transzfekcióval juttattunk Rybp-t tartalmazó, valamint a Plagl1 gén promóterét tartalmazó luciferáz riporter konstrukt plazmidokat különböző koncentrációkban. A transzfekció után 48 órával a sejteket lizáltuk, majd luciferáz riporter assay kit használatával, luminométer segítségével, megmértük a sejtlizátumokban a luciferáz aktivitást.

\section{EREDMÉNYEK ÖSSZEFOGLALÁSA}

- $\quad$ az rybp homozigóta mutáns őssejtek képesek voltak embrionális testeket képezni, de a neurális irányba való differenciációjuk zavart szenvedett. Morfológiai vizsgálatok kimutatták, hogy a mutáns őssejtekből létrehozott embrionális testekben nagyobb számban képződtek „,neurális rozetta-szerü” struktúrák, a letapasztott kultúrában pedig a mutáns sejtek kevésbé összetett neurális hálózatot alkottak, mint a vad típusú sejtek.

- a differenciálódó rybp homozigóta mutáns sejtekben a pluripotencia faktorok ugyanúgy megfelelően lecsengtek, mint a vad típusú differenciálódó sejtekben.

- a neurális differenciáció során egyes polikomb komplex tagok (Ring1a, Ring1b, Ezh1, Ezh2) és egyes szabályozó faktoraik (Yy1, Jmj) expressziójában nem volt jelentős különbség a két sejtvonalat összehasonlítva.

- az rybp homozigóta mutáns embrionális testekben mindhárom fó csíralemez (endoderma, mezoderma, ektoderma) megfelelően kifejlődött, csakúgy, mint a vad típusú embrionális testekben.

- a korai neurális folyamatok markerei (Pax6, Nestin, NeuroD1) magasabb expressziót mutattak az Rybp hiányában, mint jelenlétében a differenciálódó sejtekben. Az immuncitokémiai analízis eredményei azt mutatták, hogy a mutáns kultúrákban mind az expresszió mértéke, mind az immunpozitivitást mutató sejtek száma magasabb volt.

- a késői neurális markerek (Tubb3, NeuN, Gfap, Olig2), továbbá az axonális és dendritikus markerek (Tau, Map2) csökkent expressziós szintet mutattak a mutáns 
neurális kultúrákban a vad típushoz viszonyítva, valamint a neurális nyúlványok képzésének zavarát is észleltük.

- a génexpressziós eredmények azt mutatták, hogy a Plagl1 transzkripciós faktor nem expresszálódott az Rybp hiányában a neurális differenciáció teljes folyamata során.

- a neurális differenciáció során a különböző sejtciklusokban található sejtek eloszlásában nem volt különbség a két sejtvonal között, tehát az Rybp hiánya nem okozott változást a sejtciklusban.

- $\quad$ az Rybp hiányában több sejt vett részt az apoptózis folyamatában a neurális folyamatok során.

- a luciferáz riporter assay eredményei arra utalnak, hogy az Rybp képes volt aktiválni a Plagl1 gént a promóterén keresztül.

\section{KONKLÚZIÓ}

Munkám során az Rybp neurális differenciációs folyamatokban betöltött szerepét vizsgáltam. Ennek során vad típusú és rybp homozigóta mutáns őssejtek in vitro neurális indukcióját alkalmaztam. Bár a mutáns őssejtek képesek voltak embrionális testeket képezni, azon belül csíralemezeket formálni, majd neurális őssejteket és neurális prekurzorokat képezni; az érett neuronok, asztrociták és oligodendrociták képzése zavart szenvedett. Eredményeink rámutatnak arra, hogy az rybp homozigóta mutáns neurális progenitorokból kisebb mértékben képződnek érett neurális formák, a defektus a neuronokat, az asztrocitákat és az oligodendrocitákat is érinti. Megfigyeltük még a Plagl1 teljes hiányát az rybp homozigóta mutáns sejtekben, amely arra mutat rá, hogy a Plagl1 az Rybp egyik „downstream” célgénje, valamint feltételezhető, hogy az Rybp, a Plagll és más transzkripciós faktorok egy közös szabályozó útvonal tagjaiként fejtik ki hatásukat. Ezek alapján elmondható, hogy az Rybp esszenciális szerepet játszik a neurális specializáció folyamatában. 
Appendix B: Unigene and Mouse Genome Informatics (MGI) ID numbers of examined markers 


\begin{tabular}{|c|c|c|c|}
\hline Short ID & Entrez gene name & $\begin{array}{c}\text { Unigene ID } \\
\text { number }\end{array}$ & $\begin{array}{c}\text { MGI ID } \\
\text { number }\end{array}$ \\
\hline Ezh1 & Enhancer of zeste homolog 1 & 5027 & 1097695 \\
\hline Ezh2 & Enhancer of zeste homolog 2 & 246688 & 107940 \\
\hline Fgf5 & Fibroblast growth factor 5 & 5055 & 95519 \\
\hline Gfap & Glial fibrillary acidic protein & 1239 & 95697 \\
\hline Gsc & Goosecoid & 129 & 95841 \\
\hline Hprt & Hypoxanthine phosphoribosyltransferase 1 & 299381 & 96217 \\
\hline Jmj & Jumonji & 25059 & 104813 \\
\hline Map2 & Microtubule-associated protein 2 & 256966 & 97175 \\
\hline Nanog & Nanog homeobox & 485537 & 1919200 \\
\hline Nes & Nestin & 331129 & 101784 \\
\hline NeuN & Neuronal nuclei & 341103 & 106368 \\
\hline NeuroD1 & Neurogenic differentiation 1 & 4636 & 1339708 \\
\hline Oct4 & Octamer-binding protein 4 & 17031 & 101893 \\
\hline Olig2 & Oligodendrocyte transcription factor 2 & 37289 & 1355331 \\
\hline Pax6 & Paired box 6 & 33870 & 97490 \\
\hline Plagl1 & Pleiomorphic adenoma gene-like 1 & 287857 & 1100874 \\
\hline Ring1a & Ring finger protein 1 & 20343 & 1101770 \\
\hline Ring1b & Ring finger protein 2 & 474038 & 1101759 \\
\hline Rybp & Ring1 and Yy1 binding protein & 321633 & 1929059 \\
\hline Sox2 & YRY (sex determining region Y)-box 2 & 65396 & 98364 \\
\hline Sox17 & SRY (sex determining region Y)-box 17 & 279103 & 107543 \\
\hline Tau & Tau & 1287 & 97180 \\
\hline Tubb3 & Yin and yang 1 protein & 3868 & 107813 \\
\hline Yy1 & & 99150 \\
\hline
\end{tabular}

Table S1 
Appendix C: Tables from genome wide profiling 


increase
\begin{tabular}{|c|c|c|c|}
\hline ID & Entrez Gene Name & Fold Change & $\begin{array}{c}\text { False Discovery } \\
\text { Rate (q-value) }\end{array}$ \\
\hline Car12 & Carbonic anhydrase XII & 52,000 & $1,42 \mathrm{E}-02$ \\
\hline Fam213a & Family with sequence similarity 213, member A & 6,559 & $3,39 \mathrm{E}-03$ \\
\hline Hmgn3 & High mobility group nucleosomal binding domain 3 & 9125,000 & $1,01 \mathrm{E}-02$ \\
\hline Mov1011 & Mov10 RISC complex RNA helicase like 1 & 6,090 & $1,74 \mathrm{E}-02$ \\
\hline P4ha2 & Prolyl 4-hydroxylase, alpha polypeptide II & 9,708 & $1,74 \mathrm{E}-02$ \\
\hline Piwil2 & Piwi-like RNA-mediated gene silencing 2 & 8,906 & $1,37 \mathrm{E}-02$ \\
\hline Six1 & SIX homeobox 1 & 75,000 & $1,74 \mathrm{E}-02$ \\
\hline Stk31 & Serine/threonine kinase 31 & 7,568 & $1,66 \mathrm{E}-02$ \\
\hline Tbx3 & T-box 3 & 4,634 & $5,96 \mathrm{E}-03$ \\
\hline Tdrkh & Tudor and KH domain containing & 8,429 & $7,09 \mathrm{E}-03$ \\
\hline Tex11 & Testis expressed 11 & 39,500 & $7,13 \mathrm{E}-06$ \\
\hline Tex15 & Testis expressed 15 & 9,000 & $2,72 \mathrm{E}-03$ \\
\hline
\end{tabular}

\section{Table S2}

\begin{tabular}{|c|c|c|c|}
\hline decrease & Entrez Gene Name & Fold Change & $\begin{array}{c}\text { False Discovery } \\
\text { Rate (q-value) }\end{array}$ \\
\hline ID & Chloride channel calcium activated 4 & $-10,000$ & $1,86 \mathrm{E}-03$ \\
\hline Clca4 & DeAD (Asp-Glu-Ala-Asp) box helicase 3, Y-linked & $-6,269$ & $1,74 \mathrm{E}-02$ \\
\hline Dnmt31 & DNA (cytosine-5-)-methyltransferase 3-like & $-4,617$ & $4,08 \mathrm{E}-03$ \\
\hline Esrp1 & Epithelial splicing regulatory protein 1 & $-6,000$ & $2,37 \mathrm{E}-03$ \\
\hline Fgfr2 & Fibroblast growth factor receptor 2 & $-7,629$ & $9,76 \mathrm{E}-06$ \\
\hline Grh12 & Grainyhead-like 2 (Drosophila) & $-6,732$ & $1,82 \mathrm{E}-02$ \\
\hline Gstm2 & Glutathione S-transferase mu 1 & $-22,000$ & $3,14 \mathrm{E}-02$ \\
\hline Ina & Internexin neuronal intermediate filament protein, & $-5,525$ & $1,68 \mathrm{E}-02$ \\
\hline Klhl13 & Kelch-like family member 13 & $-7,107$ & $3,20 \mathrm{E}-07$ \\
\hline Lrp2 & Low density lipoprotein receptor-related protein 2 & $-4,360$ & $3,14 \mathrm{E}-02$ \\
\hline Meg3 & Maternally expressed 3 & $-14,510$ & $2,30 \mathrm{E}-10$ \\
\hline Pax6 & Paired box 6 & $-16,727$ & $9,76 \mathrm{E}-06$ \\
\hline Plag11 & Pleiomorphic adenoma gene-like 1 & $-13,862$ & $2,38 \mathrm{E}-05$ \\
\hline Ptch1 & Patched 1 & $-6,344$ & $1,43 \mathrm{E}-05$ \\
\hline Rybp & Ring1 and Yy1 binding protein & $-154,000$ & $1,00 \mathrm{E}-12$ \\
\hline Thbs1 & Thrombospondin 1 & $-9,294$ & $2,17 \mathrm{E}-02$ \\
\hline Tpm1 & Tropomyosin 1, alpha & $-3,190$ & $2,76 \mathrm{E}-02$ \\
\hline Trim36 & Tripartite motif containing 36 & $-70,000$ & $8,41 \mathrm{E}-03$ \\
\hline Uty & Ubiquitously transcribed tetratricopeptide repeat & $-6,976$ & $1,64 \mathrm{E}-02$ \\
\hline Wt1 & Wene Y chromosome & $-7,667$ & $1,74 \mathrm{E}-02$ \\
\hline
\end{tabular}

\section{Table S3}


Appendix D: Off-prints of thesis related publications 
Kovács, G., Szabó, V., Pirity, M.K., Absence of Rybp Compromises Neural Differentiation of Embryonic Stem Cells. Stem Cells Int. (2015) doi: $10.1155 / 2016 / 4034620$

(2.813 impact factor) 


\title{
Absence of Rybp Compromises Neural Differentiation of Embryonic Stem Cells
}

\author{
Gergo Kovacs, Viktoria Szabo, and Melinda K. Pirity \\ Institute of Genetics, Laboratory of Embryonic and Induced Pluripotent Stem Cells, Biological Research Centre, \\ Hungarian Academy of Sciences, Temesvári krt. 62, Szeged 6726, Hungary
}

Correspondence should be addressed to Melinda K. Pirity; pirity.melinda@brc.mta.hu

Received 30 June 2015; Revised 11 August 2015; Accepted 16 August 2015

Academic Editor: Su-Chun Zhang

Copyright (c) 2016 Gergo Kovacs et al. This is an open access article distributed under the Creative Commons Attribution License, which permits unrestricted use, distribution, and reproduction in any medium, provided the original work is properly cited.

Rybp (Ringl and Yyl Binding Protein) is a transcriptional regulator and member of the noncanonical polycomb repressive complex 1 with essential role in early embryonic development. We have previously described that alteration of Rybp dosage in mouse models induced striking neural tube defects (NTDs), exencephaly, and disorganized neurocortex. In this study we further investigated the role of Rybp in neural differentiation by utilising wild type $\left(r y b p^{+/+}\right)$and rybp null mutant $\left(r y b p^{-/-}\right)$embryonic stem cells (ESCs) and tried to uncover underlying molecular events that are responsible for the observed phenotypic changes. We found that $r y b p$ null mutant ESCs formed less matured neurons, astrocytes, and oligodendrocytes from existing progenitors than wild type cells. Furthermore, lack of rybp coincided with altered gene expression of key neural markers including Pax6 and Plagll pinpointing a possible transcriptional circuit among these genes.

\section{Introduction}

Complex network of transcription factors (TFs) control the gene expression in the developing embryo that manages complex differentiation processes. TFs also have important roles in the adult life in maintaining the pattern of differentiated gene expression and several of them function in multisubunit protein complexes [1]. Rybp (Ring1 and Yyl Binding Protein, also known as Dedaf (Death Effector Domain-Associated Factor), Yeaf1 (Yy1 and E4tf1 Associated Factor 1); UniGene Mm.321633; MGI:1929059) is an evolutionarily conserved TF. It is also a member of the noncanonical mammalian polycomb repressive complex 1 (PRC1) $[2,3]$. PRCs are important regulators of organogenesis and cell lineage specification because they are able to maintain pluripotency and repress differentiation. Rybp also acts as a bridging factor between E2f and Yyl binding sites on target gene promoters, thus facilitating the formation of different multimeric TF complexes [4]. Complexes that form through these binding sites play important role in regulating cell proliferation and differentiation of multiple tissue lineages during early embryonic development. Rybp is also part of the BCOR complex (named after its BCL-6 corepressor subunit) [5], which plays important role in the differentiation of embryonic stem cells (ESCs) into ectoderm and mesoderm [6] and also is required for neurogenesis [7].

Our laboratory previously showed that Rybp is essential for early embryonic development, upregulated in certain cell types of the developing central nervous system (CNS), and that in a portion of the $r y b p^{+/-}$mice alterations in Rybp dosage resulted in striking neural tube defects (NTDs) and disorganization of the neocortex in vivo [8].

Here, we further characterized the role of Rybp in neural development. We utilized wild type $\left(r y b p^{+/+}\right)$and rybp null mutant $\left(r y b p^{-/-}\right)$ESCs, which lack functional Rybp protein, and differentiated them in vitro to neural lineages in order to reveal the function of Rybp in neural differentiation. Based on the in vivo evidences we hypothesized that in the absence of Rybp ESCs cannot undergo neural differentiation or have impaired neural differentiation ability. We showed impairment in neural lineage entry of ESCs in the lack of functional Rybp during in vitro neural differentiation. When analyzed in depth, the tumor suppressor Plagll (Pleomorphic Adenoma Gene-like 1 also known as Zacl (Zinc Finger Protein Regulating Apoptosis and Cell-cycle Arrest) 
and Lot1 (Lost on Transformation 1) UniGene Mm.287857; MGI:1100874) was one of the most downregulated genes in the Rybp deficient cells. Since Plagll is a critical regulator of neural differentiation $[9,10]$ our results suggest that Plagll may, at least partially, mediate the effects of Rybp during neural differentiation.

\section{Materials and Methods}

2.1. Chemicals. All chemicals were purchased from SigmaAldrich (St. Louis, MO, USA), and culture media reagents were purchased from Invitrogen Life Technologies (Carlsbad, CA, USA), unless stated otherwise.

2.2. Cell Lines and Culture Condition. Mouse (129SV/Ola) R1 [11] (hereafter mentioned as $r y b p^{+/+}$, control, or wild type) and D11 [8] (hereafter mentioned as $r y b p^{-/-}$or null mutant) (Figure S1 in Supplementary Material available online at http://dx.doi.org/10.1155/2015/4034620) ESCs were thawed on mitomycin $\mathrm{C}$ inactivated mouse embryonic fibroblast (MEF) layer and cultured on gelatin coated tissue culture plates as described [12]. The cells were maintained in ES medium: Dulbecco's Modified Eagle's medium (DMEM (1x) + GlutaMAX-I Dulbecco's Modified Eagle Medium, Gibco, REF 31966-021) contained 15\% (vol/vol) fetal bovine serum (Gemini Stasis Stem Cell Qualified FBS, West Sacramento, CA, USA, Cat. Number 100-125), 0.1 mM nonessential amino acids (MEM Nonessential Amino Acids (100x), PAA, Cat. Number M11-003), $0.1 \mathrm{mM} \beta$-mercaptoethanol (2-Mercaptoethanol, Gibco, REF 31350-010), $50 \mathrm{U} / \mathrm{mL}$ penicillin/streptomycin (Penicillin/Streptomycin (100x), PAA, Cat. Number P11-010), and $1000 \mathrm{U} / \mathrm{mL}$ Leukemia Inhibitory Factor (LIF, ESGRO, Chemicon/Millipore, Billerica, MA, USA). The cells were passaged prior to reaching $70 \%$ confluency (approximately every 1-2 days). ESCs were cultured on gelatin coated dishes for at least two passages prior to differentiation to deplete potentially present MEF cells from the ESC culture. Cells were cultured in a humidified atmosphere containing $5 \% \mathrm{CO}_{2}$ at $37^{\circ} \mathrm{C}$. ES medium was changed daily.

2.3. Induction of Neural Differentiation by Retinoic Acid. ESCs were induced to differentiate into neuronal lineages as previously described, with some modifications (Figure 1(a)) [13]. In brief, mouse ESCs were harvested as single cell suspension using $0.05 \%$ (wt/vol) trypsin (Trypsin-EDTA (1x) $0.05 \% / 0.02 \%$ in D-PBS, PAA, Cat. Number L15-004) and then seeded at a density of $4.5 \times 10^{5}$ cells $/ \mathrm{mL}$ in ES medium without LIF into $100 \mathrm{~mm}^{2}$ bacteriological dishes where cell attachment was prevented. ESCs were allowed to aggregate in suspension and form embryoid bodies (EBs) for 8 days. Medium was changed on every second day during differentiation unless stated otherwise. On the 4th day of EB formation $5 \mu \mathrm{M}$ all-trans retinoic acid (RA) (retinoic acid, Sigma, Cat. Number R2625-100MG) was added to the medium and EBs were cultured for a further 4 days in the presence of RA. Thereafter, 8-day-old EBs were dissociated using trypsin and plated onto poly-L-ornithine (Poly-L-Ornithine $0.01 \%$, Sigma, Cat. Number P4957) and laminin (Laminin from
Engelbreth-Holm-Swarm murine sarcoma basement membrane, Sigma, Cat. Number L2020-1MG) coated dishes at a density of $3 \times 10^{5}$ cells $/ \mathrm{cm}^{2}$ in DMEM/F-12 medium containing $3 \mathrm{mg} / \mathrm{mL}$ of D-(+)-glucose, $3 \mathrm{mg} / \mathrm{mL}$ AlbuMax I, $50 \mathrm{U} / \mathrm{mL}$ penicillin/streptomycin, and $1 \%$ (vol/vol) N-2 supplement (N-2 Supplement (100x), Gibco, Cat. Number 17502-048), and $10 \mathrm{ng} / \mathrm{mL}$ recombinant human bFGF (Fibroblast Growth Factor Basic, human, Sigma, Cat. Number F0291-25UG); the medium was changed 24 hours later. Two days after cells were plated, the medium was changed to DMEM/F12:Neuronal Base Medium (Neuronal Base Medium For Neuronal Cells, PAA, Cat. Number U15-023) (1:1), 1 mM GlutaMax, 3 mg/mL AlbuMax I, $50 \mathrm{U} / \mathrm{mL}$ penicillin/streptomycin, $0.5 \%$ ( $\mathrm{vol} / \mathrm{vol}$ ) N-2 Supplement, and $1 \%$ (vol/vol) B-27 supplement (B-27 Supplement (50x), Gibco, Cat. Number 17504-044). The cells were harvested for further analyses on different time points of neural differentiation: days $0,3,7,10$, and 14 (labeled as $\mathrm{d} 0$, $\mathrm{d} 3, \mathrm{~d} 7, \mathrm{~d} 10$, and d14). On d10 and d14 the differentiated cells were also stained with cresyl violet in order to visualize the cell colonies and morphology of the cells. The images of the ESC cultures, EBs, and stained neural culture were obtained using Olympus cellR microscope (Olympus Corporation, Japan).

2.4. Quantitative Real-Time PCR ( $q R T-P C R)$. For quantitation of mRNA levels during the in vitro differentiation quantitative real-time PCR (qRT-PCR) assays were performed. Total RNA was extracted from the harvested cells using Qiagen RNeasy Plus Mini Kit (Qiagen, Cat. Number 74134 Hilden, Germany) according to the manufacturer's instructions. cDNA synthesis was achieved with the isolated RNA using Applied Biosystems High capacity cDNA Reverse Transcription Kit (Invitrogen Life Technologies, Cat. Number 4368814 Carlsbad, CA, USA) according to the manufacturer's instructions.

qRT-PCR was performed in SYBR Green master mix (SYBR Select Master Mix for CFX, Applied Biosystems, REF 4472942) using Bioer LineGeneK Real-time PCR System (Bioer, China). Relative gene expression changes were quantified using the $\Delta \Delta \mathrm{Ct}$ method. The threshold cycle $(\mathrm{Ct})$ values for each gene were normalized to expression level of Hprt, as internal control. To calculate fold change, the values were compared to undifferentiated samples $\left(\mathrm{d} 0, r y b p^{+/+}\right)$. The primers used in this study were listed in Supplementary Table 1 .

2.5. Immunocytochemistry Analysis. For immunofluorescence staining of the cells, they were plated onto coverslips, differentiated into neuronal lineages as described above, and fixed with $4 \%(\mathrm{v} / \mathrm{v})$ paraformaldehyde (PFA) for $20 \mathrm{~min}$ at room temperature (RT). After permeabilization in $0.2 \%$ Triton X-100 (Triton X-100, Sigma, Cat. Number T8787-250ML) in Phosphate Buffered Saline (PBS, DPBS (1x) Dulbecco's Phosphate Buffered Saline, Gibco, REF 14190-094) for $20 \mathrm{~min}$ at RT, cells were blocked in 5\% Bovine Serum Albumin (BSA) (Albumin from bovine serum, Sigma, Cat. Number A7906) in PBS for $1 \mathrm{~h}$ at RT and then sequentially incubated with the following primary antibody in 5\% BSA overnight at 


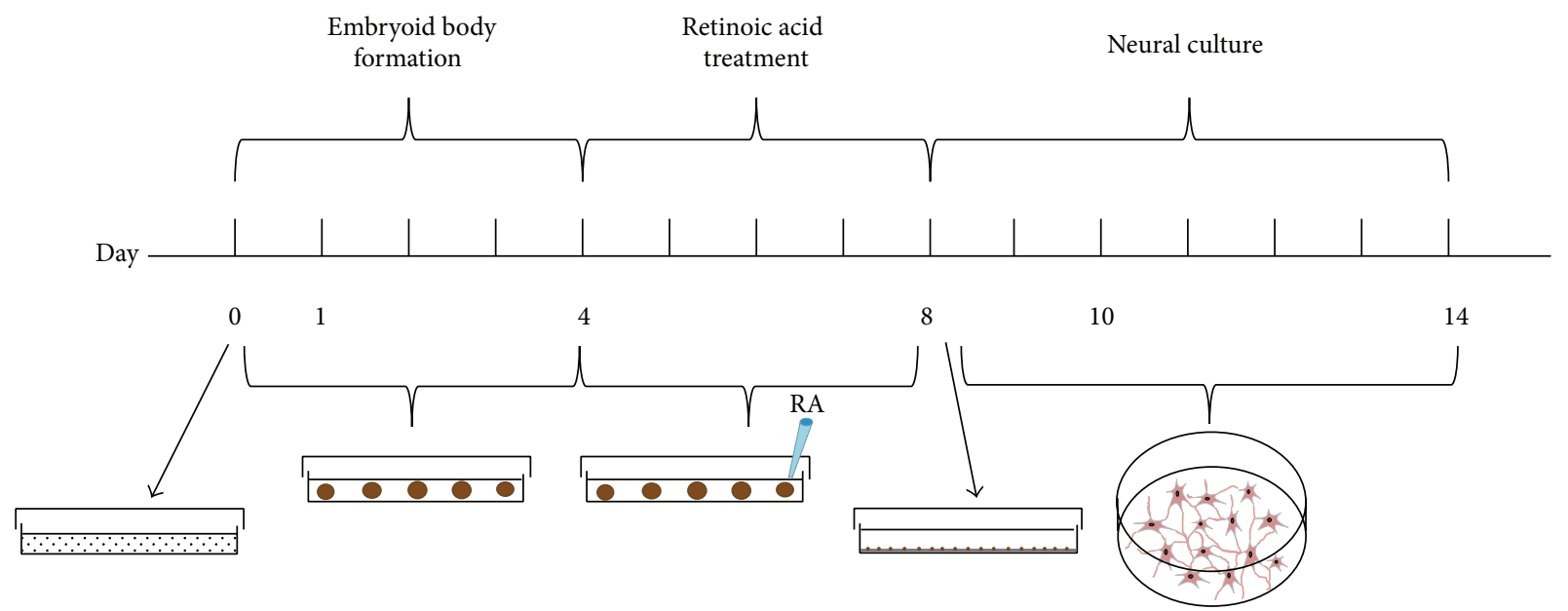

(a)
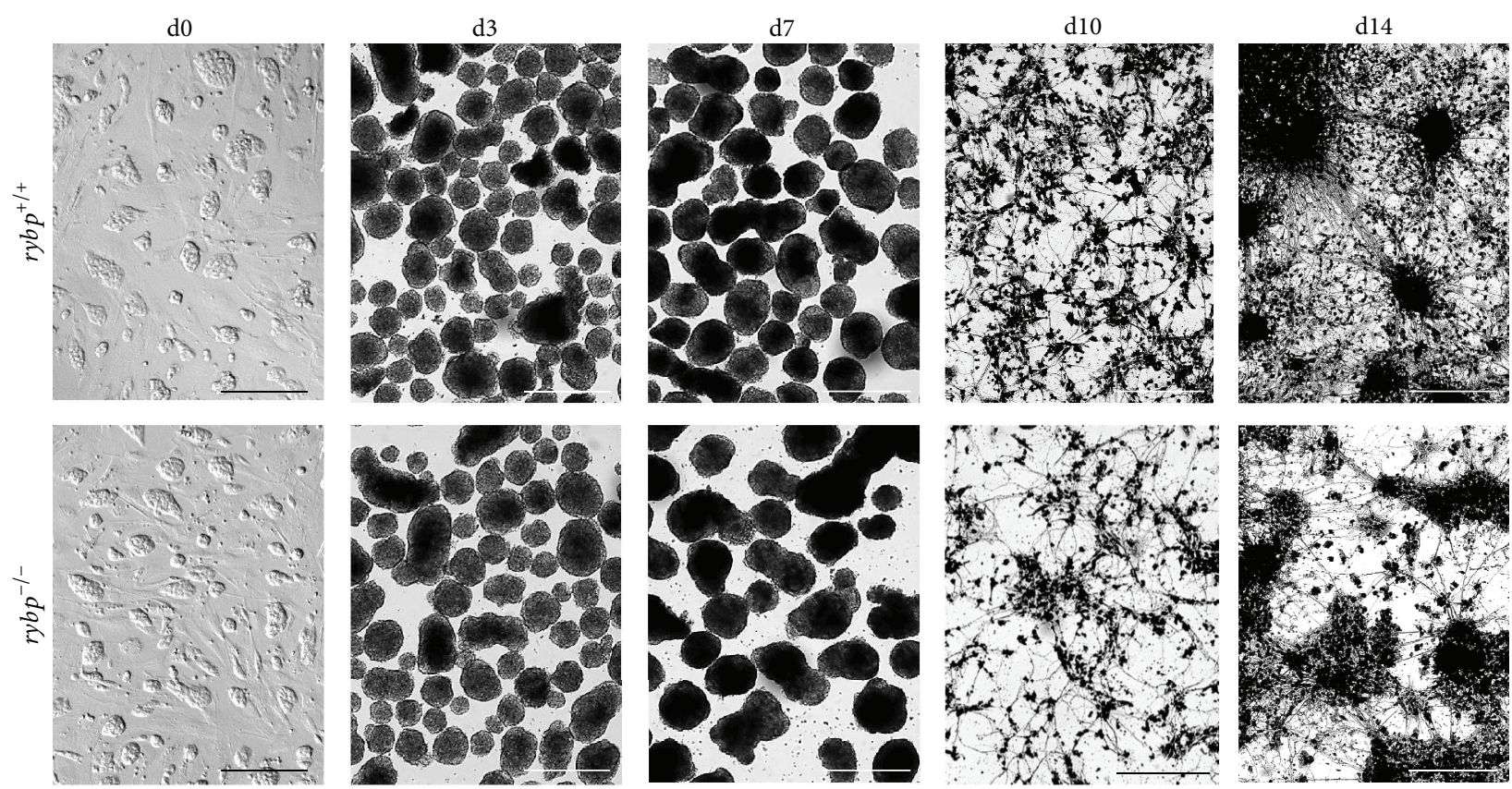

(b)

FIGURE 1: Morphological changes of $r y b p^{+/+}$and $r y b p^{-/-}$cells through in vitro neural differentiation. (a) Schematic illustration of in vitro neural differentiation as described previously by Bibel et al. (b) The rybp ${ }^{-/-}$ESCs display the same morphology in culture as the wild type (d0) and also form EBs (d3, d7). There is no noticeable difference between the two cell lines. After the plating (d10, d14) the $r y b p^{-/-}$cells grew less organized neural network than the wild type. Magnifications are $4 \mathrm{x}(\mathrm{d} 3, \mathrm{~d} 7)$ and $10 \mathrm{x}(\mathrm{d} 0, \mathrm{~d} 10, \mathrm{~d} 14)$. Scale bars represent 500 $\mu \mathrm{m}(\mathrm{d} 3$, $\mathrm{d} 7)$ and $200 \mu \mathrm{m}(\mathrm{d} 0, \mathrm{~d} 10, \mathrm{~d} 14)$.

$4^{\circ} \mathrm{C}$ : Nestin (Rat-401, Hybridoma Bank, Iowa, USA, 1:100), Pax6 (Pax6, Hybridoma Bank, Iowa, USA, 1:100), Tuj1 (Neuronal Class III $\beta$-Tubulin Polyclonal Antibody; Covance, Cat. Number PRB-435P, 1:2500), Gfap (Monoclonal Anti-Glial Fibrillary Acidic Protein Clone G-A-5, Sigma, Cat. Number G3893, 1:400), and Plagl1 (Zac1 (M-300), Santa Cruz Biotechnology, Cat. Number sc-22812, 1:1000). The cells were washed 5 times with PBS and incubated with fluorescent-labeled secondary antibodies (Alexa Fluor 647 Donkey-Anti-Mouse, Invitrogen, Cat. Number A-31571; Alexa Fluor 647 Goat-Anti-Rabbit, Invitrogen, Cat. Number
A-21244; Alexa Fluor 488 Goat-Anti-Mouse, Invitrogen, Cat. Number A-10667) for $1 \mathrm{~h}$ at RT. Then the cells were washed 3 times with PBS. The cells were rinsed in $4^{\prime}, 6$-diamidino2-phenylindole (DAPI; Vector Laboratories, Cat. Number H1200) for $20 \mathrm{~min}$, washed 2 times with PBS, and mounted in $50 \%$ glycerol. The images were obtained using Olympus LSM confocal microscope (Olympus Corporation, Japan).

2.6. Statistical Analysis. All experiments were repeated three times. Experiments were evaluated with SPSS/PC+ version 17 program (SPSS, Chicago, IL) by using $t$-test type 3. Means 
are standard deviation. Values of $P<0.05$ were accepted as significant $\left({ }^{*} P<0.05 ;{ }^{* *} P<0.01 ;{ }^{* *} P<0.001\right)$.

\section{Results}

3.1. Neural Cell Culture Differentiated from rybp ${ }^{-/-}$ESCs Exhibit Different Morphology than Wild Type. In order to investigate the possible molecular mechanisms underlying the in vivo neural phenotypes of the $r y b p^{+/-}$mice we took advantage of the ESC based in vitro neural differentiation system. Thus, we adopted the protocol by Bibel et al. [13] in order to differentiate $r y b p^{+/+}$[11] and $r y b p^{-/-}$[8] ESCs lacking functional Rybp protein product towards neural cell lineages (Figure 1(a)). In brief, suspension cultures were initiated using $4.5 \times 10^{5}$ cells $/ \mathrm{mL}$ initial seeding density and were kept in suspension for 8 days to form EBs. RA was added to the suspension cultures on $\mathrm{d} 4$ and EBs were kept in RA supplemented medium until trypsinization on $\mathrm{d} 8$ and then seeded on poly-L-ornithine/laminin coated surfaces and differentiated further for another week. Samples for analysis were taken at $\mathrm{d} 0, \mathrm{~d} 3, \mathrm{~d} 7, \mathrm{~d} 10$, and $\mathrm{d} 14$ and processed as required. $R y b p^{-/-}$ESCs display similar morphology in culture as the control cell line (Figure 1(b) d0) and by d7 EBs grew larger compared to $\mathrm{d} 3$ in both cell lines (Figure 1(b), $\mathrm{d} 3, \mathrm{~d} 7)$ suggesting that $r y b p^{-1-}$ cells are not compromised in their ability to form EBs and proliferate. As expected, after plating EBs on poly-L-ornithine and laminin coated surfaces, the wild type cells exhibited typical neuronal morphology and the cells grew axon-like outgrowth, connected to each other, and organized in a complex network consisting of heterogeneous cell population (Figure 1(b) d10, d14). However, $r y b p^{-/-}$cells grew less neurite processes and their organization into network was less extended in comparison to the wild type. This phenotype was independent from the initial cell density (Figure 1(b), d10, d14; data not shown). The gross morphology of the cells suggests that neuronal differentiation was affected by absence of rybp.

3.2. Expression of Pluripotency Markers in the Lack of Rybp during Neural Differentiation. To uncover underlying mRNA expression changes during in vitro neural differentiation we evaluated gene expression levels by qRT-PCR. First, we confirmed that the $r y b p^{-/-}$cells do not produce functional protein (Figure 2(a)). Then we analyzed the expression of pluripotency markers in both cell lines. Incomplete silencing of the pluripotency genes during differentiation inhibits neural differentiation. The analysis revealed that the expression of examined pluripotency markers Oct 4 and Nanog was progressively downregulated in both cell lines by differentiation (Figures 2(b) and 2(c)) and there were no significant changes in the kinetics of pluripotency gene expression between the $r y b p^{+/+}$and $r y b p^{-/-}$cells.

Sox 2 together with Oct4 and Nanog maintains pluripotency in stem cells and neural progenitors (NPCs) and, in addition, Sox 2 is also important in the induction of neuroectoderm $[14,15]$. The relative expression levels of Sox 2 in both cell lines are similar with the exception of $\mathrm{d} 14$ when the level of Sox 2 is diminished in the rybp null mutant whilst it stays high in the wild type (Figure $2(\mathrm{~d})$ ). This suggests that the differentiation ability of rybp null stem cells to NPCs or maintaining the characteristics of NPCs might be compromised. These results suggested that the silencing of key pluripotency genes exhibits similar kinetics with the exception of Sox2, which in the rybp null mutants drastically declines by $\mathrm{d} 14$.

3.3. Expression of Key Neural Markers in the Lack of Rybp during Neural Differentiation. After examination of the key pluripotency markers we analyzed the relative gene expression of key neural markers (e.g., Nestin, Pax6, NeuroD1, Tubb3, NeuN, Gfap, and Olig2) in both cell lines to gain information about the kinetics of neural differentiation.

Nestin is a widely employed marker of multipotent neural stem cells (NSCs) [16]. Once the cells become differentiated, Nestin expression is downregulated both in vivo and in vitro [17]. As expected, at the time of neural induction (d7, RA treatment) Nestin is strongly upregulated at $\mathrm{d} 7$ in both cell lines (Figure 3(a)). Nestin expression increased further after plating of the cells (d10) and its level decreased only at later phases of neural differentiation (d14) in both cell lines (Figure 3(a)). Notably, Nestin expression was more robust in the $r y b p^{-/-}$cell line compared to the $r y b p^{+/+}$at $\mathrm{d} 10$. Immunocytochemistry with Nestin antibody confirmed the presence of NPCs in both cell lines with stronger expression in the $r y b p^{-/-}$cells at d10 (Figure 4(a)). By the endpoint of in vitro neural differentiation (d14) the number of Nestin expressing cells was reduced in both cell lines (Figure 4(a); Figure S2(a) and (b)). These results suggest that early neural processes take place in a greater extent in the absence of functional Rybp.

Paired Box 6 (Pax6) gene is required for the initiation of neural differentiation and described as an essential factor for normal eye development as well [18]. Relative gene expression analysis revealed that Pax6 is upregulated after the RA treatment (Figure 3(b) from d7) and its level decreased at later time points of neural differentiation (d14) in the wild type cells. Expression of Pax6 was higher after neuroectodermal induction in the $r y b p^{-/-}$cells compared to the wild type (Figure 3(b) from d7). Pax6 immunostaining visualizes the distribution of Pax 6 positive cells in the wild type and mutant neural cell cultures (Figure 4(b)). The Pax6 signal was stronger in the mutant cultures in all examined time points (Figure 4(b); Figure S2(c) and (d)). In both cell lines the number of Pax6 positive cells is higher at d10 when early differentiation events take place. These results correlate with the data of Pax6 qRT-PCR analysis and indicate an abundance of Pax6 positive cell population in the rybp null mutants.

Neurogenic Differentiation 1 (NeuroD1) is a TF, which is essential for terminal neuronal commitment of maturing neurons [19]. NeuroD1 drives premature differentiation of neuronal precursors into mature neurons. Relative gene expression analysis by qRT-PCR showed that the NeuroD1 is mildly expressed after RA treatment (d7) in both cell lines (Figure 3(c)). The expression level of NeuroD1 is significantly higher at early stage (d10) in the mutant cell line compared to the wild type. The expression of NeuroD1 decreased by 


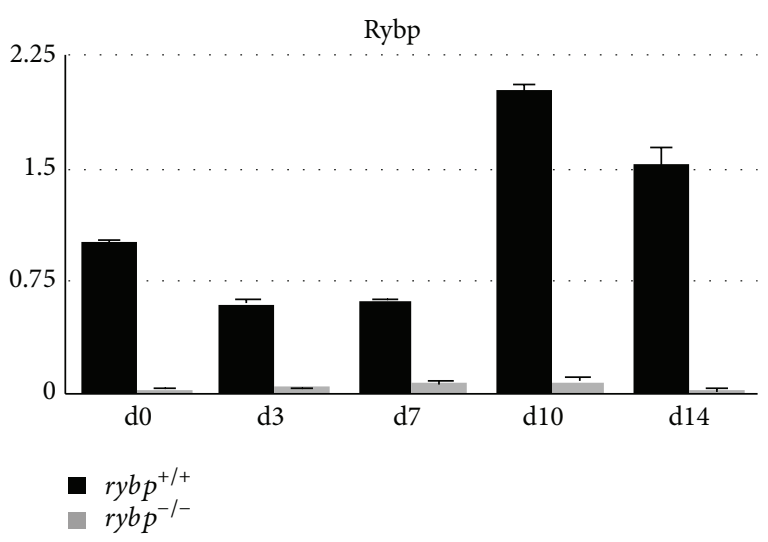

(a)

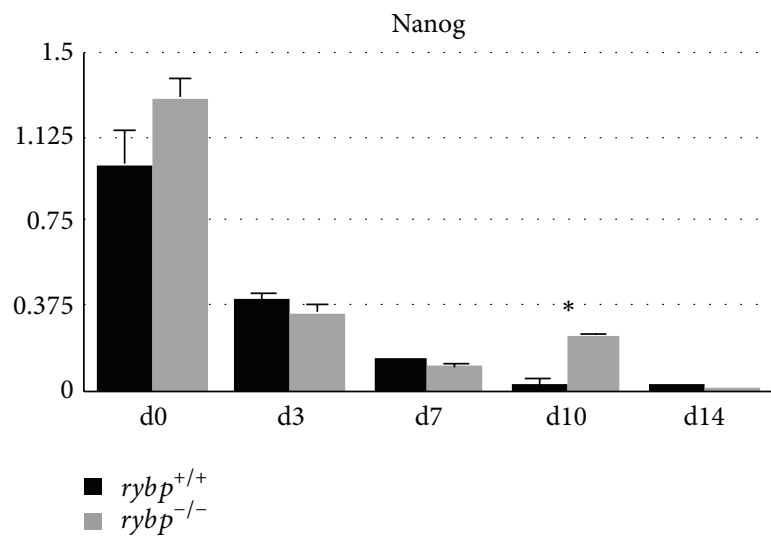

(c)

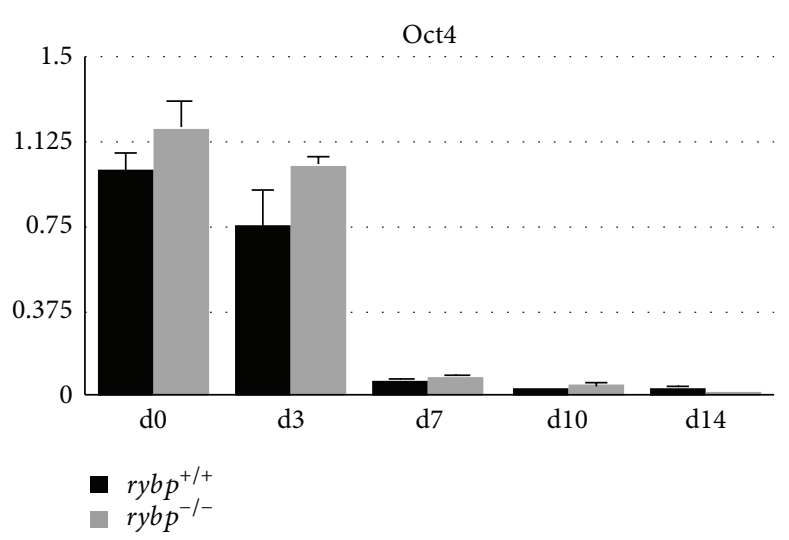

(b)

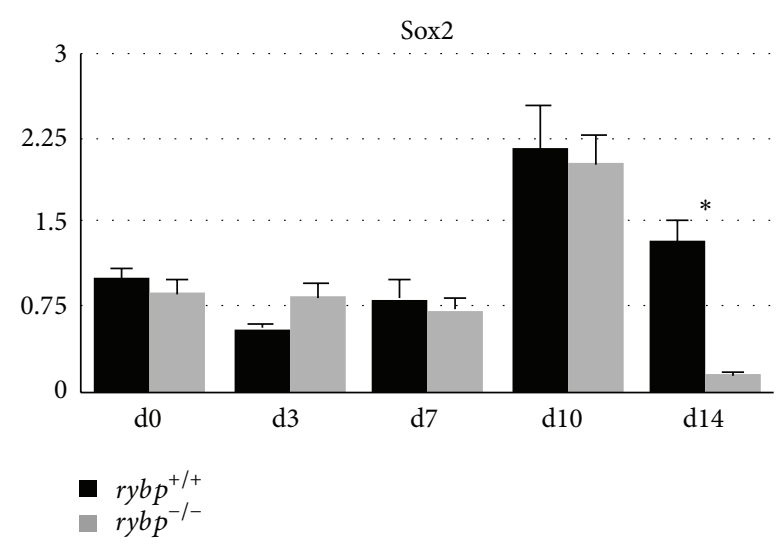

(d)

FIGURE 2: In the lack of Rybp there is no change in silencing of key pluripotency markers (Oct4, Nanog) during in vitro neural differentiation. Relative gene expressions of Rybp (a), Oct4 (b), Nanog (c), and Sox2 (d) were analyzed by qRT-PCR. For the analysis RNA was extracted and reverse-transcribed from differentiated neural cell culture generated from $r y b p^{+/+}$and $r y b p^{-/-}$ESCs. Samples are collected at days $0,3,7,10$, and 14 of differentiation. The expression of the indicated markers was normalized to Hprt expression, which was used as an internal control. Means are standard deviation. Values of $P<0.05$ were accepted as significant $\left({ }^{*} P<0.05 ;{ }^{* *} P<0.01 ;{ }^{* * *} P<0.001\right)$. Statistical method: $t$ test type 3.

the end of differentiation (d14) in the rybp ${ }^{-/-}$cells whilst there is only a minor decrease in its level in the $r y b p^{+/+}$ cells. At d14, NeuroD1 expression is higher in the wild type cells compared to the mutants. This also confirms that the characteristics of NPCs are altered in the rybp null mutants: at the beginning/mid-phase of differentiation ( $\mathrm{d} 7$ and 10$)$ the premature differentiation of NPCs is accelerated but by the end of differentiation (d14) it is attenuated.

Class III Beta-Tubulin (Tubb3) plays a critical role in proper axon guidance, maintenance, and axonal transport $[20,21]$ and also is expressed in postmitotic phase of differentiating neurons [22]. Relative gene expression analysis by qRT-PCR showed that Tubb3 expression is elevated at early stage (d10) in both cell lines but its expression declines in the $r y b p^{-1-}$ cells at later stage of neural differentiation (d14) while its level still remains high in the wild type (Figure 3(d)). In order to visualize ongoing neural differentiation spatiotemporally we stained the cells with Tuj1 antibody, which marks Tubb3 positive cells. The assessment of Tuj1 staining (Figure 4(c); Figure S2(e) and (f)) showed that neurite processes and axon-like structures start to develop in both cell lines however in the $r y b p^{+/+}$cells exhibit a complex and dense network of outgrowth compared to the mutants. Notably, Tubb3 also is expressed in the soma, around the nucleus in $r y b p^{+/+}$cells, while in the $r y b p^{-/-}$ cells this staining was less visible. The reduced density of nerve fibers by ICC in the mutant cell line was consistent with the data on diminished amount of nerve bundles on Tubb3 by qRT-PCR analyses. These data suggest that a normal level of Rybp is important for the proper development of neurons.

In order to ascertain the presence of mature neurons in our cell cultures we assessed the relative gene expression changes of postmitotic neuronal marker NeuN (also known as Rbfox3). NeuN marks the nuclei of maturing and differentiated neurons [23]. As expected, qRT-PCR analysis showed that NeuN was abundantly expressed in the plated wild type neural cultures (d10, d14) but its level stayed constantly low in the mutants (Figure 3(e)). This indicates that much less mature neurons formed in the rybp null mutant culture (d10, d14) and further confirms the compromised differentiation ability of rybp null NPCs. 


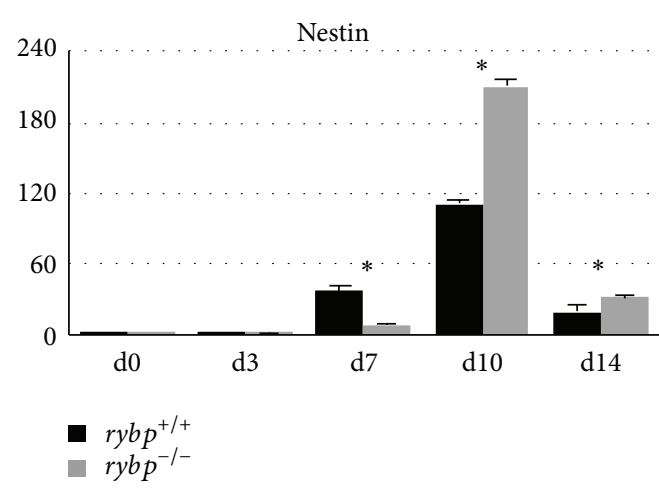

(a)

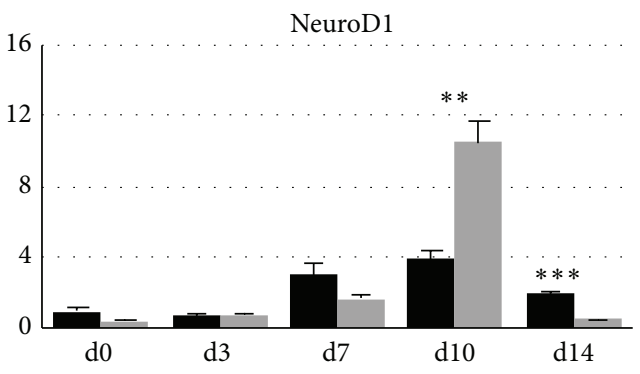

- $r y b p^{+/+}$

- $r y b p^{-1-}$

(c)

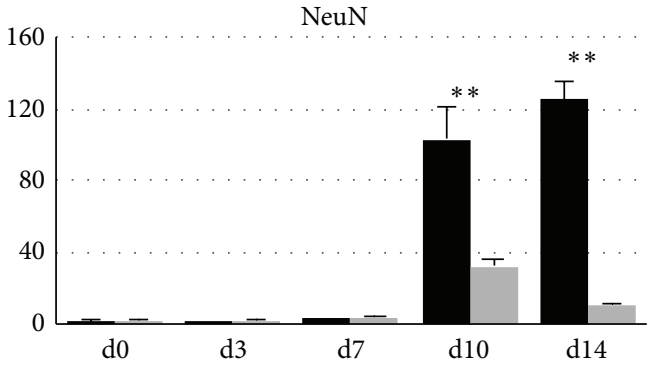

- $r y b p^{+/+}$

$r y b p^{-1-}$

(e)

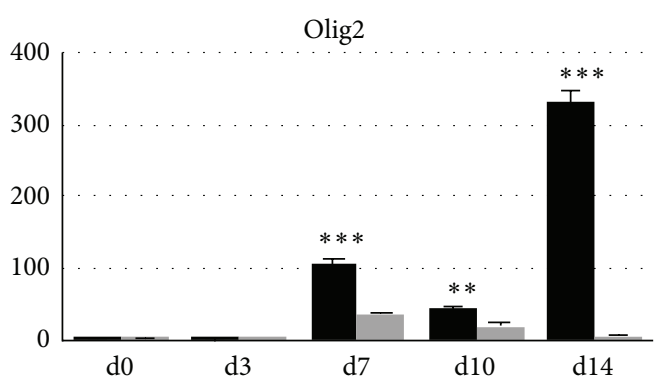

- $r y b p^{+/+}$

- $r y b p^{-1-}$

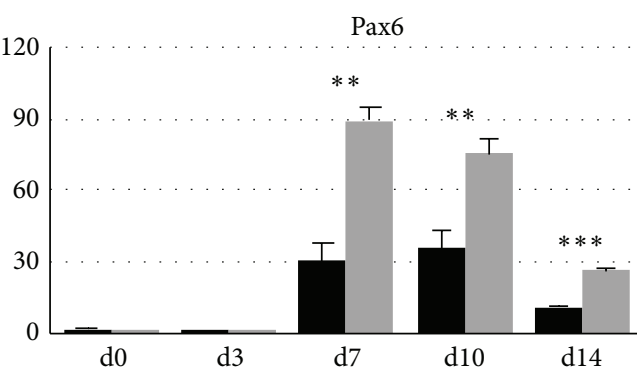

- $r y b p^{+/+}$

- rybp

(b)

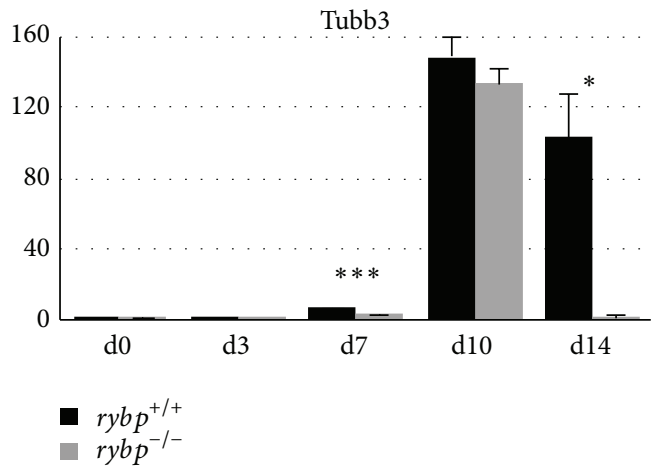

(d)

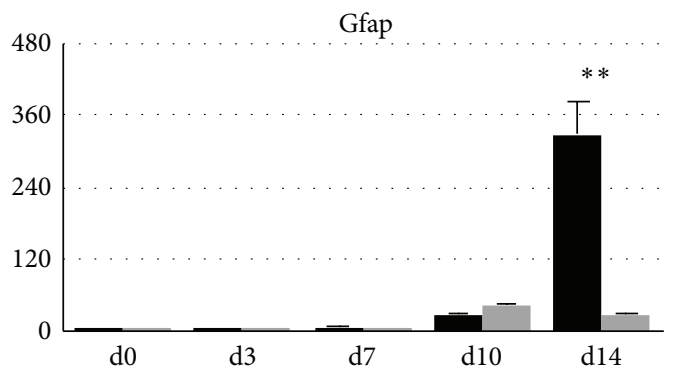

- $r y b p^{+/+}$

- $r y b p^{-1-}$

(f)

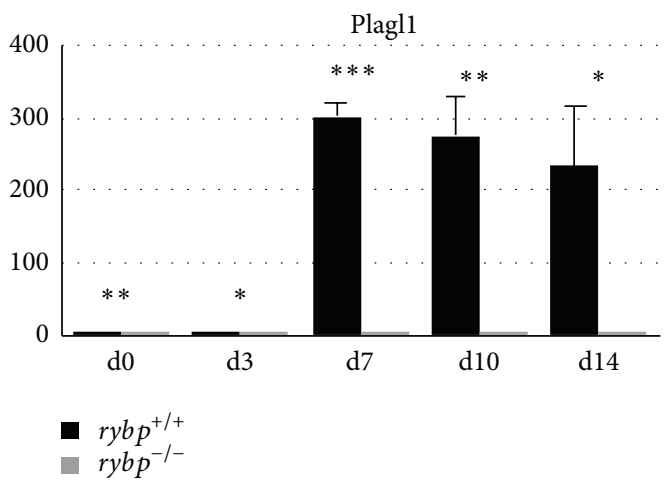

(h)

Figure 3: Neural markers (Nestin (a), Pax6 (b), NeuroD1 (c), Tubb3 (d), NeuN (e), Gfap (f), and Olig2 (g)) and transcription factor, Plagl1 (h), exhibit altered expression in the lack of Rybp during in vitro neural differentiation. Relative gene expression of key neural markers was analyzed with qRT-PCR. For the analysis RNA was extracted and reverse-transcribed from differentiated neural cell culture generated from $r y b p^{+/+}$and $r y b p^{-1-}$ ESCs. Samples are collected at days $0,3,7,10$, and 14 of differentiation. The expressions of the indicated markers were normalized to Hprt expression, which was used as an internal control. Means are standard deviation. Values of $P<0.05$ were accepted as significant $\left({ }^{*} P<0.05 ;{ }^{* *} P<0.01 ;{ }^{* * *} P<0.001\right)$. Statistical method: $t$ test type 3 . 

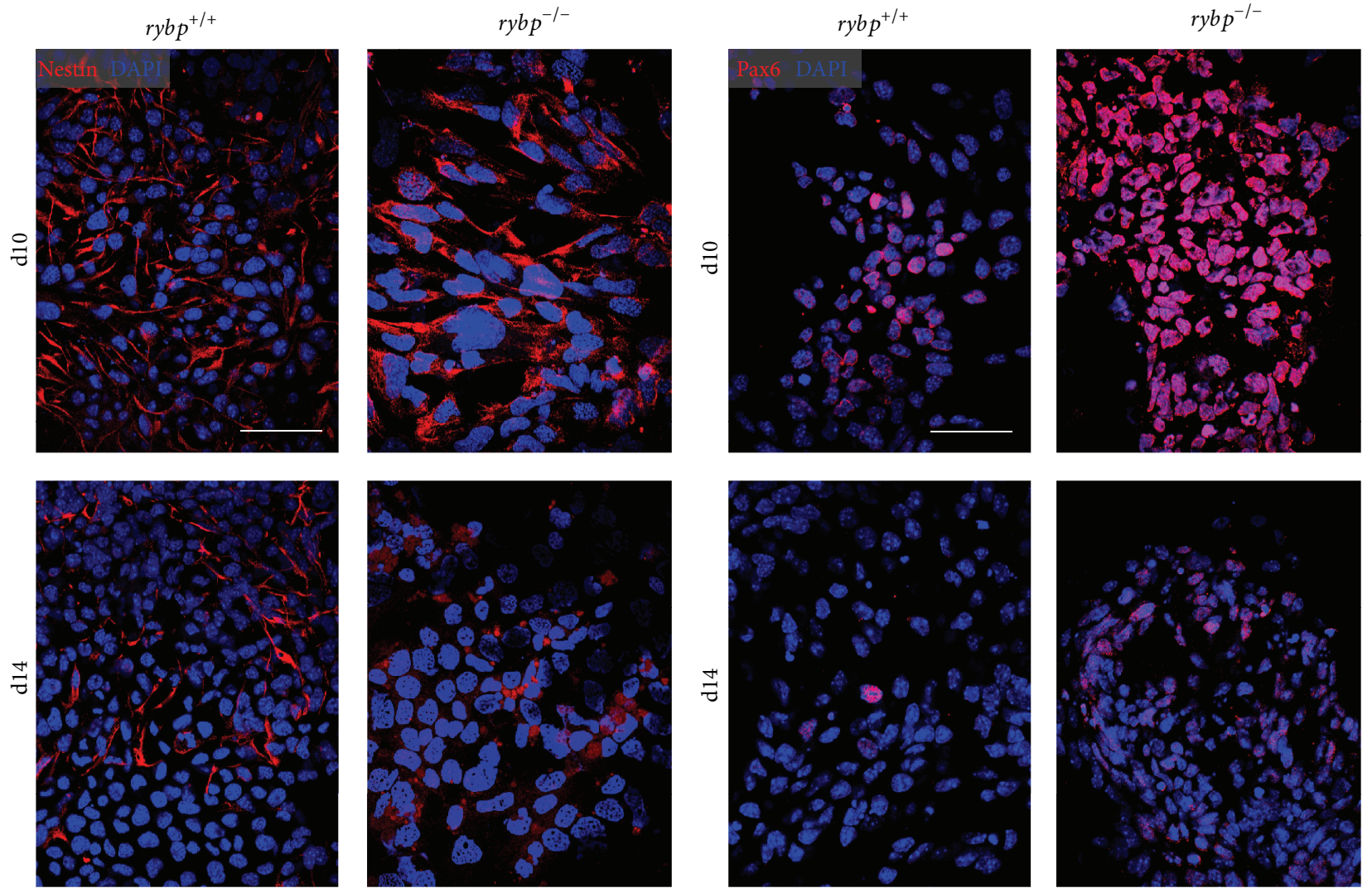

(a)

$r y b p^{-1-}$
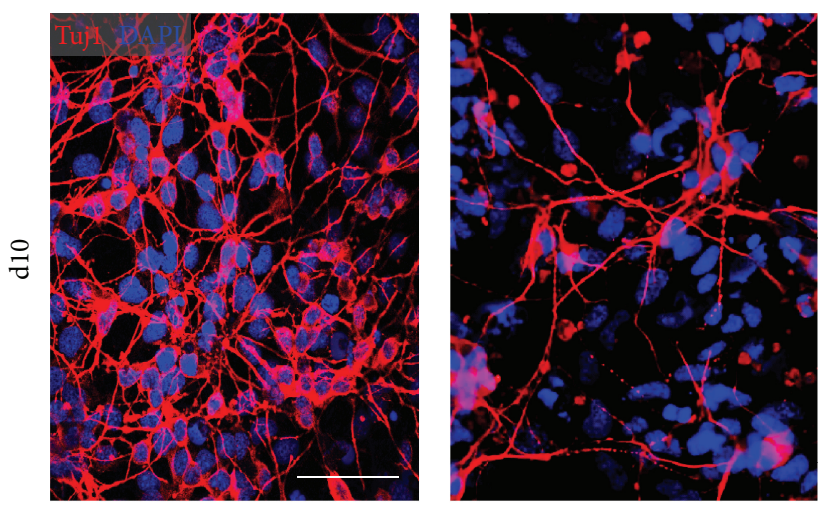

$r y b p^{+/+}$

(b)

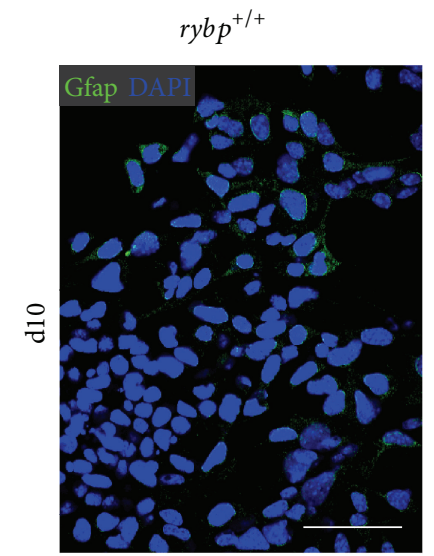

$r y b p^{-/-}$
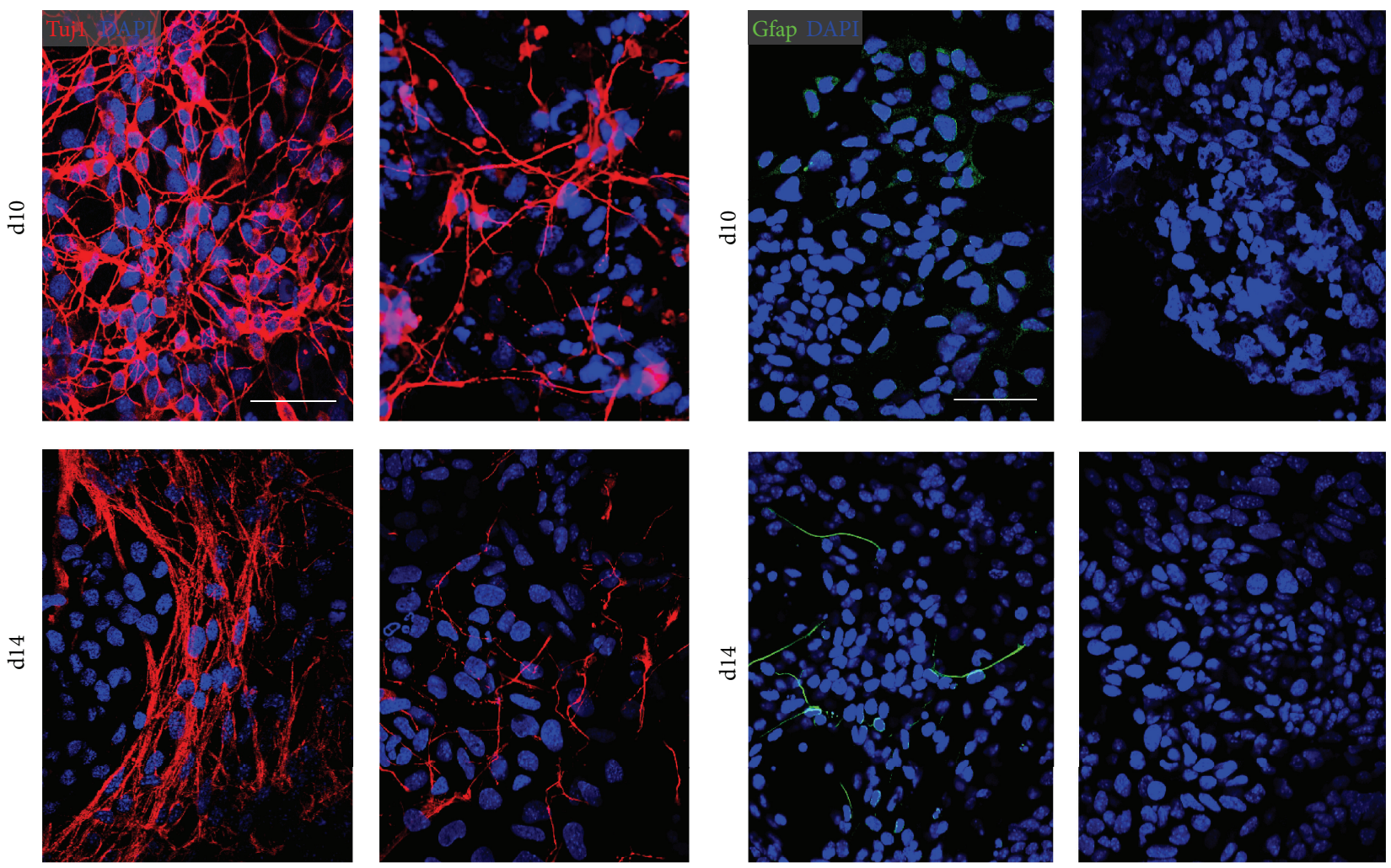

(c)

Figure 4: Continued. 

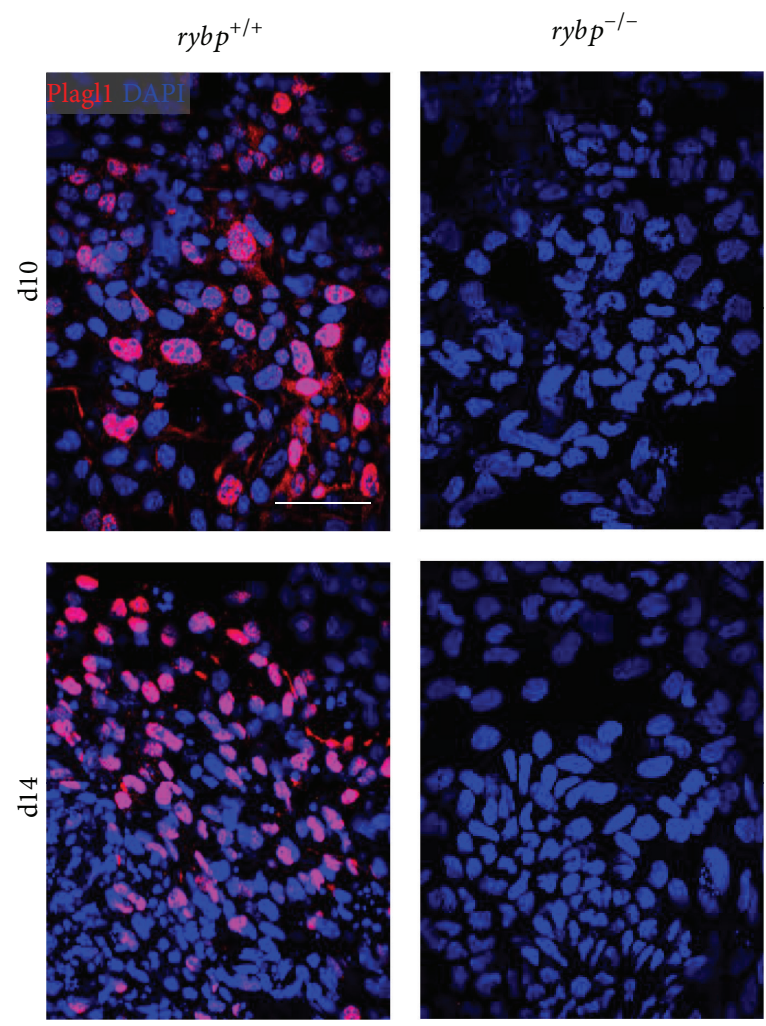

(e)

FIGURE 4: Rybp deficient cells show impaired protein expression of neural markers during in vitro neural differentiation. Immunocytochemical analysis of in vitro differentiated neural cultures shows that there are more Nestin (a) and Pax6 (b) and less Tuj1 (c) are visible in the rybp null mutant neural cell cultures by d10. Nestin and Tuj1 staining are reduced in the $r y b p^{-1-}$ cell culture by d14 compared to wild type, which indicates possible defects in the late neural processes. Immunostaining of astrocyte marker, Gfap (d), shows a small amount of astrocyte-like cells in wild type culture, which is absent in the mutant. Immunocytochemistry with antibody against Plagll (e) reveals that Plagl1 is expressed in the nucleus of $r y b p^{+/+}$cells but it is absent in $r y b p^{-/-}$cells. Magnification is 60x. Scale bars represent $60 \mu \mathrm{m}$.

This observation tempted us to speculate whether this defect is specific for neurons or other cell types like astrocytes and oligodendrocytes are also affected in the absence of Rybp. Therefore we next analyzed whether cells lacking functional Rybp are able to generate astrocytes as well. In order to do so, we have performed relative gene expression analysis by qRT-PCR in both cell lines for the intermediate filament Glial Fibrillary Acidic Protein (Gfap), which is a commonly accepted marker of radial glia and astrocytes [24]. Our analysis revealed that the level of Gfap is elevated over $300 \mathrm{x}$ in the wild type cells (Figure 3(f) d14). In comparison its level stayed low in the rybp null mutants (Figure 3(f) d14). We also analyzed the spatial distribution of Gfap by immunostaining and found that there were no Gfap positive cells in the mutant neural cultures (Figure 4(d); Figure S2(g) and $(\mathrm{h}))$. This suggests that the astrocyte differentiation is defective in the mutant cells.

We also investigated if the absence of Rybp has influence on other types of glial cells or it is specific for astrocytes. For this purpose, we measured the relative expression level of Oligodendrocyte Lineage Transcription Factor 2 (Olig2) by qRT-PCR. Olig2 is a marker gene for oligodendrocytes [25-27]. Oligodendrocyte differentiation normally starts by $\mathrm{d} 7$ and peaks by $\mathrm{d} 14$ (Figure $3(\mathrm{~g}) r y b p^{+/+}$cells). In contrast, the $r y b p^{-/-}$cells expressed 60x less Olig2 mRNAs at d14 compared to the wild type (Figure $3(\mathrm{~g})$ ). This demonstrates that oligodendrocyte differentiation is also impaired in the absence of Rybp.

3.4. Plagl1 Is a Downstream Target of Rybp during In Vitro Neural Differentiation. Previously, we have shown that Plagll is a candidate downstream gene of Rybp during in vitro cardiac differentiation of mouse embryonic stem cells [28]. Plagll has dual role; it is an important gene for cardiac development and it has also crucial role in neural development [10, 29]. Moreover, lack of Plagl1 in mouse models caused marked defects in CNS development (e.g., reduced size of cerebellum, reduced number of mature neurons) [9], which are similar to the phenotype of the $r y b p^{+/-}$mice (see above, Section 1) [8].

Therefore, next we have tested whether the differences in mRNA expression are also sustained (or changed) during neural differentiation between the wild type and rybp null mutant cell lines. Gene expression analysis (Figure 3(h)) revealed that Plagll is strongly induced $(\sim 300 \mathrm{x})$ after the RA treatment (d7) during in vitro neural differentiation in the wild type cells and remained high until the end of 
differentiation (d14). However in the rybp ${ }^{-/-}$cells Plagll was not induced and showed complete deficiency.

After this, we wanted to test whether the difference in Plagll mRNA induction is also sustained at protein level. In order to visualize the spatiotemporal distribution of Plagll throughout the differentiation process we performed immunocytochemistry of in vitro neural cultures with antibody against the Plagll protein (Figure 4(e); Figure S2(i) and (j)). This confirmed that Plagll is visible in the nuclei of the wild type cells (Figure 4(e), wild type cells at d10 and d14) while in the rybp ${ }^{-/-}$cells there is a complete lack of Plagll staining. These results showed that Plagll induction is impaired in $r y b p^{-1-}$ cells during the entire course of neural differentiation.

\section{Discussion}

Current work investigates the possible underlying molecular mechanisms responsible for the previously described phenotype of the rybp heterozygous mouse models [8]. Considerable attention has focused on the search for downstream target genes that may mediate the biological effect of Rybp in neural lineage commitment. Our study showed that the development of both neuronal and glial lineages is defective in the rybp null ESCs derivatives. Furthermore, our study establishes that the process of differentiation towards mature neural cell types rather than to a specific lineage is impaired in the lack of Rybp.

The contribution of $r y b p^{-/-}$ESCs to neural lineage commitment is particularly interesting since in vivo evidence has been already provided that Rybp is important for neural development and it is broadly expressed in different cell types of the CNS. Moreover misexpression of Rybp was shown in glioblastomas and other types of tumors [30].

Our results showed that the properties of rybp null NPCs are compromised: rybp null NPCs express Pax6, Nestin, and NeuroD1 in excess in comparison to the wild type ones. Pax6 is one of the key transcriptional factors [31], whose level needs to be upregulated at the beginning of neural development since Pax6 plays important role in establishing neuronal progenitor pool during the vertebrate nervous system development [32] (Figure 5). At the same time downregulation of Pax6 is also necessary for the forthcoming, late neural differentiation. In our assays when Rybp is absent, Pax6 is upregulated. Since high level of Pax6 obstructs terminal differentiation of NPCs it is possible that this elevated level of Pax6 helps to keep NPCs at the early stage of differentiation and inhibits the forthcoming late neural processes in the rybp ${ }^{-/-}$cells [33] (Figure 5). Upregulation of Nestin and NeuroD1 also confirms that early neural processes are accelerated in the lack of Rybp compared to the wild type. At the same time, silencing of key pluripotency genes (e.g., Oct4, Nanog) is a well coordinated event in the absence of Rybp indicating that improper silencing of pluripotency genes cannot be the causative of the phenotype. The only exception is Sox 2 since the pool of Sox 2 positive cells is reduced in the rybp null mutants earlier than in the wild type neural cultures. Sox 2 is not only a critical factor for maintaining pluripotency and directing the differentiation of stem cells to neural progenitors but it is also important for maintaining the properties of NPCs [15]. Downregulation of Sox 2 resulted in progenitor cells losing capability to both proliferate and terminally differentiate [34]; however to determine how Sox 2 dose-change alters the state of NPCs in neural differentiation is a debate of future studies. Since others already described that striking increase of Pax6 partially rescues the Sox 2 mutant phenotype [35], it cannot be excluded that increased level of Pax6 in the null mutant compensates the effect of low level of Sox2. It is possible that the lack of Rybp alters the balance among major transcription factors governing the NPC pool generation and consequent differentiation events. Changing the expression level of one or more members in these circuits will shift the finely tuned balance and initiate premature differentiation. Alternatively, this suboptimal balance may exhaust the NPC pool, which obscures consequent differentiation events, since Rybp is a moonlighting protein and is involved in such diverse biological functions as ubiquitination [3], apoptosis [36], and transcriptional repression [4], and it may have multiple roles in regulating neural differentiation as well. It further complicates the situation that Yaf2 (the other member of the Rybp/Yaf2 gene family) may compensate for the lack of Rybp at certain extent $[37,38]$.

Decreased level of late neuronal markers (Tuj1, NeuN, Gfap, and Olig2) indicates that maturing of neurons, oligodendrocytes, and astrocytes are deficient in the rybp null mutant cells (Figure 5). Parallel with these, the mutant cells seem to form a larger NPC pool (d10) and less astrocytes and oligodendrocytes in comparison to the wild types (d14). Overall, these observations confirm that maturation of neurons, astrocytes, and oligodendrocytes are deficient in the rybp null mutant cells and this process is not lineage specific.

The other gene whose expression is drastically changed in the $r y b p^{-1-}$ neural cultures is Plagll, which is an important regulator of neural development, apoptosis, and cell-cycle arrest whereas it has antiproliferative activity [39, 40]. Plagl1 is normally expressed in the progenitor cells of ventricular zone, subventricular zone, and external granular cell layer of the brain and promotes cell-cycle withdrawal of NPCs during the differentiation processes [10]. The tight regulation of cell-cycle processes is required to ensure timely generation and correct amount of the various neural cell types, which largely depends on the presence of Plagll. The observation that Plagll is almost completely downregulated in the absence of functional Rybp and the fact that Rybp and Plagll deficient mice exhibit similar development defects (reduced number of mature neurons, reduced size of cerebellum, etc.) indicate a possible genetical or biochemical link between Rybp and Plagl1 $[8,9]$. In our study increased level of Pax6 is accompanied by the downregulation of Plagll in Rybp deficient cells. In the absence of functional Rybp it is very likely that the balance of early and late neural processes is "unbalanced," which is probably linked to the upregulation of Pax6 and/or the loss of Plagll (Figure 5).

Possibilities for action of Rybp are likely very diverse. Recent studies showed that Rybp is a member of the recently 


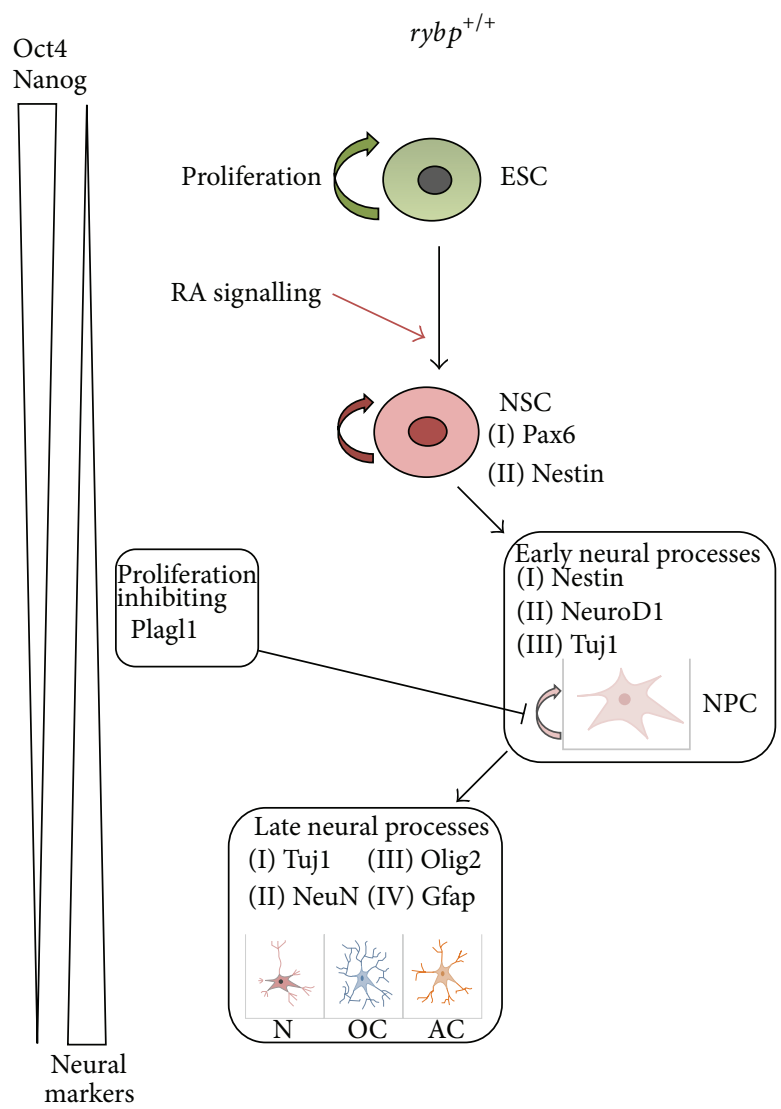

(a)

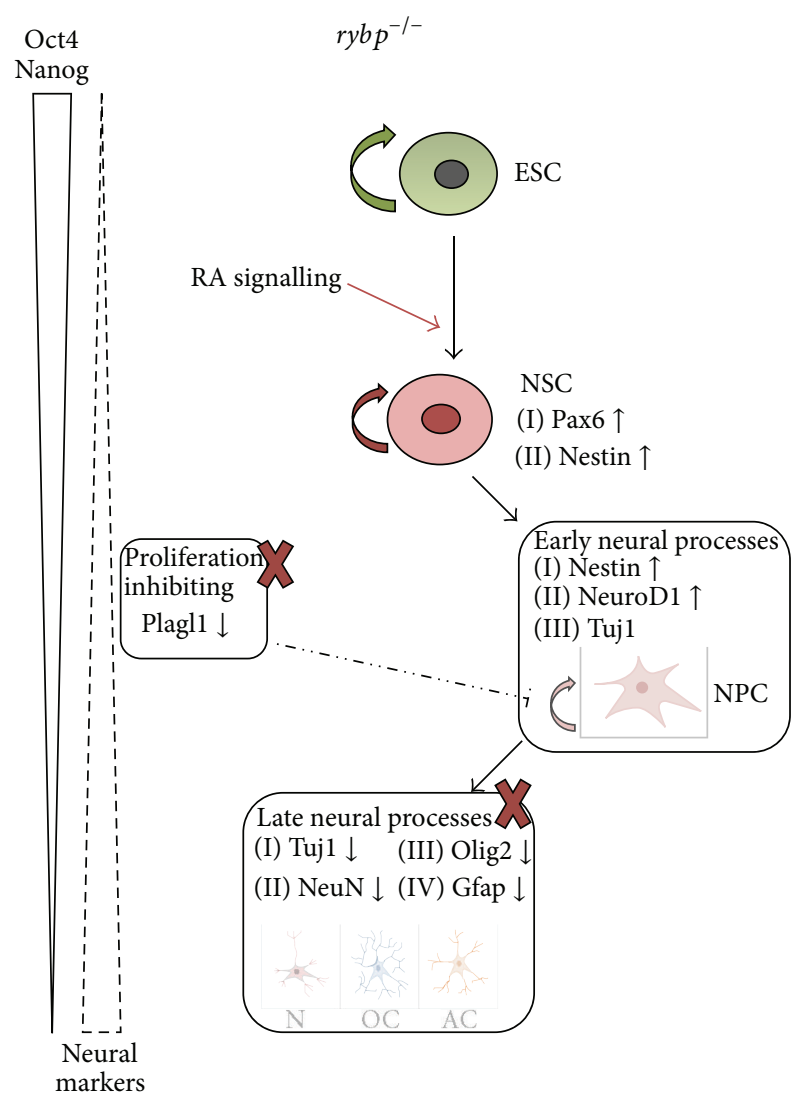

(b)

FIGURE 5: Model of in vitro neural differentiation in ESCs in presence and absence of Rybp. (a) Differentiation of wild type ESCs towards matured cell types of the CNS in the presence of Rybp. Pluripotent ESCs express key pluripotency markers (e.g., Oct4, Nanog) in undifferentiated state, which are gradually decreasing through in vitro neural differentiation. Parallel with this, early neural markers (Pax6, Nestin) are upregulated in NSCs, which will confer reduced proliferative and high differentiation capacity to the cells. On the other hand, in the presence of Rybp, upregulation of Plagll helps to facilitate late neural differentiation and inhibits cell proliferation, which will facilitate the generation of terminally differentiated neural cell types (N, OC, and AC). By the progression of neural differentiation, NPCs will differentiate further and start to express markers of specialized neural cell types (Tuj1, NeuN, Olig2, and Gfap). (b) Differentiation of pluripotent ESCs towards matured cell types of the CNS is impaired in the absence of Rybp. During neural differentiation early neural markers (Pax6, Nestin) exhibit elevated expression level in the rybp null mutants. These will facilitate the generation of a bigger pool of NPCs with higher proliferative capacity. On the other hand, in the absence of Rybp, Plagll expression is defective, which also contributes to increased proliferative and decreased differentiation capacity of the NPCs. As a result, the formation of terminally differentiated neural cell types (N, OC, and AC) will be impaired in the lack of functional Rybp. ESC: embryonic stem cell; NSC: neural stem cell; NPC: neural progenitor cell; N: neuron; OC: oligodendrocyte; AC: astrocyte; RA: retinoic acid; CNS: central nervous system.

identified noncanonical PRC1 complex with unknown biological functions [41]. This complex is also encompassing $\mathrm{Kdm} 2 \mathrm{~b}$, a gene with essential function during embryonic development. Notably, loss of $\mathrm{Kdm} 2 \mathrm{~b}$ is perinatally lethal with incomplete neural tube closure, exencephaly, and altered cell-cycle processes in NPCs [42] mimicking the phenotype of the $r y b p$ heterozygous mice [8]. Kdm2b, like Rybp, is also the member of the BCOR complex [5], which also plays important role in neurogenesis suggesting further possible functional cooperation between the two genes [7]. Importantly, members of the PRCs are proven to play important role in neural development: loss of Ring1B, which is core member of the canonical PRC1 and binding partner of Rybp, causes premature neuronal differentiation [43]. Ezh2, a core member of the PRC2, is highly expressed in NPCs and downregulated through the differentiation of mature cortical neurons [44].
Notably, Neurogenin 1, has been found to be suppressed by a PRC mediated mechanism at the neuronal-to-astrocytic transition of NPC differentiation during corticogenesis [45]. To clarify whether Rybp is functioning as the member of PRCs or other multimeric protein complexes during neural development is a debate of future studies.

\section{Conflict of Interests}

The authors state that they have no conflict of interests.

\section{Authors' Contribution}

Melinda K. Pirity and Gergo Kovacs conceived and designed the experiments. Gergo Kovacs and Viktoria Szabo executed 
the experiments. Melinda K. Pirity and Gergo Kovacs analyzed the data. Melinda K. Pirity and Gergo Kovacs wrote the paper.

\section{Acknowledgment}

This work was supported by NKTH-OTKA FP7 "Mobility" HUMAN-MB08C-80205.

\section{References}

[1] E. H. Davidson, J. P. Rast, P. Oliveri et al., "A genomic regulatory network for development," Science, vol. 295, no. 5560, pp. 1669$1678,2002$.

[2] E. Garcia, C. Marcos-Gutiérrez, M. del Mar Lorente, J. C. Moreno, and M. Vidal, "RYBP, a new repressor protein that interacts with components of the mammalian Polycomb complex, and with the transcription factor YY1," The EMBO Journal, vol. 18, no. 12, pp. 3404-3418, 1999.

[3] L. Tavares, E. Dimitrova, D. Oxley et al., "RYBP-PRC1 complexes mediate $\mathrm{H} 2 \mathrm{~A}$ ubiquitylation at polycomb target sites independently of PRC2 and H3K27me3," Cell, vol. 148, no. 4, pp. 664-678, 2012.

[4] S. Schlisio, T. Halperin, M. Vidal, and J. R. Nevins, "Interaction of YY1 with E2Fs, mediated by RYBP, provides a mechanism for specificity of E2F function," The EMBO Journal, vol. 21, no. 21, pp. 5775-5786, 2002.

[5] M. D. Gearhart, C. M. Corcoran, J. A. Wamstad, and V. J. Bardwell, "Polycomb group and SCF ubiquitin ligases are found in a novel BCOR complex that is recruited to BCL6 targets," Molecular and Cellular Biology, vol. 26, no. 18, pp. 6880-6889, 2006.

[6] J. A. Wamstad, C. M. Corcoran, A. M. Keating, and V. J. Bardwell, "Role of the transcriptional corepressor Bcor in embryonic stem cell differentiation and early embryonic development," PLoS ONE, vol. 3, no. 7, Article ID e2814, 2008.

[7] L. Tiberi, J. Bonnefont, J. vandenAmeele et al., "A BCL6/BCOR/SIRT1 complex triggers neurogenesis and suppresses medulloblastoma by repressing Sonic Hedgehog signaling," Cancer Cell, vol. 26, no. 6, pp. 767-812, 2014.

[8] M. K. Pirity, J. Locker, and N. Schreiber-Agus, "Rybp/DEDAF is required for early postimplantation and for central nervous system development," Molecular and Cellular Biology, vol. 25, no. 16, pp. 7193-7202, 2005

[9] S.-H. Chung, H. Marzban, K. Aldinger et al., "Zacl plays a key role in the development of specific neuronal subsets in the mouse cerebellum," Neural Development, vol. 6, no. 1, article 25, 2011.

[10] T. Valente and C. Auladell, "Expression pattern of Zacl mouse gene, a new zinc-finger protein that regulates apoptosis and cellular cycle arrest, in both adult brain and along development," Mechanisms of Development, vol. 108, no. 1-2, pp. 207-211, 2001.

[11] A. Nagy, J. Rossant, R. Nagy, W. Abramow-Newerly, and J. C. Roder, "Derivation of completely cell culture-derived mice from early-passage embryonic stem cells," Proceedings of the National Academy of Sciences of the United States of America, vol. 90, no. 18, pp. 8424-8428, 1993.

[12] T. M. Magin, J. McWhir, and D. W. Melton, "A new mouse embryonic stem cell line with good germ line contribution and gene targeting frequency," Nucleic Acids Research, vol. 20, no. 14, pp. 3795-3796, 1992.
[13] M. Bibel, J. Richter, K. Schrenk et al., "Differentiation of mouse embryonic stem cells into a defined neuronal lineage," Nature Neuroscience, vol. 7, no. 9, pp. 1003-1009, 2004.

[14] S. Masui, Y. Nakatake, Y. Toyooka et al., "Pluripotency governed by Sox 2 via regulation of Oct3/4 expression in mouse embryonic stem cells," Nature Cell Biology, vol. 9, no. 6, pp. 625-635, 2007.

[15] V. Graham, J. Khudyakov, P. Ellis, and L. Pevny, "SOX2 functions to maintain neural progenitor identity," Neuron, vol. 39 , no. 5, pp. 749-765, 2003.

[16] U. Lendahl, L. B. Zimmerman, and R. D. G. McKay, "CNS stem cells express a new class of intermediate filament protein," Cell, vol. 60 , no. 4 , pp. 585-595, 1990.

[17] D. Park, A. P. Xiang, F. F. Mao et al., "Nestin is required for the proper self-renewal of neural stem cells," Stem Cells, vol. 28, no. 12, pp. 2162-2171, 2010.

[18] R. E. Hill, J. Favor, B. L. M. Hogan et al., "Mouse Small eye results from mutations in a paired-like homeobox-containing gene," Nature, vol. 354, no. 6354, pp. 522-525, 1991.

[19] C. Boutin, O. Hardt, A. de Chevigny et al., "NeuroD1 induces terminal neuronal differentiation in olfactory neurogenesis," Proceedings of the National Academy of Sciences of the United States of America, vol. 107, no. 3, pp. 1201-1206, 2010.

[20] M. M. Black, J. M. Cochran, and J. T. Kurdyla, "Solubility properties of neuronal tubulin: evidence for labile and stable microtubules," Brain Research, vol. 295, no. 2, pp. 255-263, 1984.

[21] A. Ferreira and A. Caceres, "Expression of the class III $\beta$ tubulin isotype in developing neurons in culture," Journal of Neuroscience Research, vol. 32, no. 4, pp. 516-529, 1992.

[22] M. L. Fanarraga, "Expression of unphosphorylated class III $\beta$ tubulin isotype in neuroepithelial cells demonstrates neuroblast commitment and differentiation," European Journal of Neuroscience, vol. 11, no. 2, pp. 517-527, 1999.

[23] R. J. Mullen, C. R. Buck, and A. M. Smith, "NeuN, a neuronal specific nuclear protein in vertebrates," Development, vol. 116, no. 1, pp. 201-211, 1992.

[24] C. M. Jacque, C. Vinner, M. Kujas, M. Raoul, J. Racadot, and N. A. Baumann, "Determination of glial fibrillary acidic protein (GFAP) in human brain tumors," Journal of the Neurological Sciences, vol. 35, no. 1, pp. 147-155, 1978.

[25] R. Mizuguchi, M. Sugimori, H. Takebayashi et al., "Combinatorial roles of Olig2 and Neurogenin2 in the coordinated induction of pan-neuronal and subtype-specific properties of motoneurons," Neuron, vol. 31, no. 5, pp. 757-771, 2001.

[26] H. Takebayashi, Y. Nabeshima, S. Yoshida, O. Chisaka, K. Ikenaka, and Y.-I. Nabeshima, "The basic helix-loop-helix factor olig2 is essential for the development of motoneuron and oligodendrocyte lineages," Current Biology, vol. 12, no. 13, pp. 1157-1163, 2002.

[27] Q. Zhou, S. Wang, and D. J. Anderson, "Identification of a novel family of oligodendrocyte lineage-specific basic helixloop-helix transcription factors," Neuron, vol. 25, no. 2, pp. 331$343,2000$.

[28] O. Ujhelly, V. Szabo, G. Kovacs et al., "Lack of rybp in mouse embryonic stem cells impairs cardiac differentiation," Stem Cells and Development, 2015.

[29] T. Valante, F. Junyent, and C. Auladell, "Zacl is expressed in progenitor/stem cells of the neuroectoderm and mesoderm during embryogenesis: differential phenotype of the Zacl-expressing cells during development," Developmental Dynamics, vol. 233, no. 2, pp. 667-679, 2005. 
[30] W. Wang, J. Cheng, J.-J. Qin et al., "RYBP expression is associated with better survival of patients with hepatocellular carcinoma (HCC) and responsiveness to chemotherapy of HCC cells in vitro and in vivo," Oncotarget, vol. 5, no. 22, pp. 1156711582, 2014.

[31] S. Gajović, L. St-Onge, Y. Yokota, and P. Gruss, "Retinoic acid mediates Pax6 expression during in vitro differentiation of embryonic stem cells," Differentiation, vol. 62, no. 4, pp. 187-192, 1998.

[32] J. Ericson, P. Rashbass, A. Schedl et al., "Pax6 controls progenitor cell identity and neuronal fate in response to graded Shh signaling," Cell, vol. 90, no. 1, pp. 169-180, 1997.

[33] S. Bel-Vialar, F. Medevielle, and F. Pituello, "The on/off of Pax6 controls the tempo of neuronal differentiation in the developing spinal cord," Developmental Biology, vol. 305, no. 2, pp. 659-673, 2007.

[34] O. V. Taranova, S. T. Magness, B. M. Fagan et al., "SOX2 is a dose-dependent regulator of retinal neural progenitor competence," Genes and Development, vol. 20, no. 9, pp. 11871202, 2006.

[35] D. Matsushima, W. Heavner, and L. H. Pevny, "Combinatorial regulation of optic cup progenitor cell fate by SOX2 and PAX6," Development, vol. 138, no. 3, pp. 443-454, 2011.

[36] L. Zheng, O. Schickling, M. E. Peter, and M. J. Lenardo, "The death effector domain-associated factor plays distinct regulatory roles in the nucleus and cytoplasm," Journal of Biological Chemistry, vol. 276, no. 34, pp. 31945-31952, 2001.

[37] T. Kaneko, H. Miyagishima, T. Hasegawa, Y. Mizutani-Koseki, K.-I. Isono, and H. Koseki, "The mouse YAF2 gene generates two distinct transcripts and is expressed in pre-and postimplantation embryos," Gene, vol. 315, no. 1-2, pp. 183-192, 2003.

[38] C. Sawa, T. Yoshikawa, F. Matsuda-Suzuki et al., "YEAF1/RYBP and YAF-2 are functionally distinct members of a cofactor family for the YY1 and E4TF1/hGABP transcription factors," Journal of Biological Chemistry, vol. 277, no. 25, pp. 2248422490, 2002.

[39] A. Abdollahi, D. Roberts, A. K. Godwin et al., "Identification of a zinc-finger gene at 6q25: a chromosomal region implicated in development of many solid tumors," Oncogene, vol. 14, no. 16, pp. 1973-1979, 1997.

[40] D. Spengler, M. Villalba, A. Hoffmann et al., "Regulation of apoptosis and cell cycle arrest by Zacl, a novel zinc finger protein expressed in the pituitary gland and the brain," The EMBO Journal, vol. 16, no. 10, pp. 2814-2825, 1997.

[41] X. Wu, J. V. Johansen, and K. Helin, "Fbxl10/Kdm2b recruits polycomb repressive complex 1 to $\mathrm{CpG}$ islands and regulates H2A ubiquitylation," Molecular Cell, vol. 49, no. 6, pp. 1134-1146, 2013.

[42] T. Fukuda, A. Tokunaga, R. Sakamoto, and N. Yoshida, "Fbxl10/Kdm2b deficiency accelerates neural progenitor cell death and leads to exencephaly," Molecular and Cellular Neuroscience, vol. 46, no. 3, pp. 614-624, 2011.

[43] M. Román-Trufero, H. R. Méndez-Gómez, C. Pérez et al., "Maintenance of undifferentiated state and self-renewal of embryonic neural stem cells by polycomb protein Ring1B," Stem Cells, vol. 27, no. 7, pp. 1559-1570, 2009.

[44] A. Sparmann, Y. Xie, E. Verhoeven et al., "The chromodomain helicase Chd4 is required for Polycomb-mediated inhibition of astroglial differentiation," The EMBO Journal, vol. 32, no. 11, pp. 1598-1612, 2013.

[45] G. Testa, "The time of timing: how Polycomb proteins regulate neurogenesis," BioEssays, vol. 33, no. 7, pp. 519-528, 2011. 


\section{II.}

Ujhelly, O., Szabo, V., Kovacs, G., Vajda, F., Mallok, S., Prorok, J., Acsai, K., Hegedus, Z., Krebs, S., Dinnyes, A., Pirity, M.K. Lack of Rybp in Mouse Embryonic Stem Cells

Impairs Cardiac Differentiation. Stem Cells Dev. 24(18):2193-205. (2015)

doi: $10.1089 /$ scd.2014.0569

(3.727 impact factor) 


\title{
Lack of Rybp in Mouse Embryonic Stem Cells Impairs Cardiac Differentiation
}

\author{
Olga Ujhelly, ${ }^{1}$ Viktoria Szabo, ${ }^{2}$ Gergo Kovacs, ${ }^{2}$ Flora Vajda, ${ }^{2}$ Sylvia Mallok, ${ }^{3}$ Janos Prorok, ${ }^{4}$ \\ Karoly Acsai, ${ }^{5}$ Zoltan Hegedus, ${ }^{6}$ Stefan Krebs, ${ }^{3}$ Andras Dinnyes, ${ }^{1,7}$ and Melinda Katalin Pirity ${ }^{2}$
}

Ring1 and Yy1 binding protein (Rybp) has been implicated in transcriptional regulation, apoptotic signaling and as a member of the polycomb repressive complex 1, it has an important function in regulating pluripotency and differentiation of embryonic stem cells (ESCs). Earlier, we had proved that Rybp plays an essential role in mouse embryonic and central nervous system development. This work identifies Rybp, as a critical regulator of heart development. Rybp is readily detectable in the developing mouse heart from day 8.5 of embryonic development. Prominent Rybp expression persists during all embryonic stages, and Rybp marks differentiated cell types of the heart. By utilizing rybp null ESCs in an in vitro cardiac differentiation assay, we found that rybp null ESCs do not form rhythmically beating cardiomyocytes (CMCs). Gene expression profiles revealed a downregulation of cardiac terminal and upregulation of germline-specific markers in the rybp null CMCs. Furthermore, transcriptome analysis uncovered a number of novel candidate target genes regulated by Rybp. Among these are several that are important in cardiac development and contractility such as Plagl1, Isl1, and Tnnt2. Importantly, forced expression of rybp in rybp-deficient ESCs by a lentiviral vector was able to rescue the mutant phenotype. Our data provide evidence for a previously unrecognized function of Rybp in heart development and point out the importance of germ cell lineage gene silencing during somatic differentiation.

\section{Introduction}

A COMPLEX NETWORK of transcription factors governs the spatiotemporal patterns of gene expression in the organs of the developing embryo proper. Transcription factors also have important roles in postnatal and adult life in maintaining the pattern of differentiated gene expression [1-3]. Ring 1 and Yy1 binding protein [Rybp, also known as Dedaf (Death Effector Domain-Associated Factor), UniGene Mm.321633; MGI:1929059] is a repressor protein that is also a member of the mammalian polycomb repressive complex 1 (PRC1) [4]. First, Rybp was described as a binding partner for the polycomb group protein (PcG) Ring1A (Ring1; ortholog of Drosophila dRing/Sce) and was also shown to associate with Ring1B (Ring2/Rnf2; ortholog of Drosophila dRing/Sce) and M33 (Pc1; ortholog of Drosophila Pc), components of the PRC1 multiprotein complex [5].

Our previous work showed that Rybp is selectively upregulated in distinct structures and cell types of the developing eye and the central nervous system (CNS), and it may also play a role in the development of more mature neurons $[6,7]$. We have also shown that rybp is essential for the development of the mouse embryo proper and that homozygous null mouse embryos cannot develop further implantation [embryonic day 5.5 (E5.5)]. Notably, in a subset of heterozygous animals and in $r y b p^{-/-} \leftrightarrow r y b p^{+/+}$chimeras, alterations in Rybp dosage induced striking neural tube defects (NTDs) [6,7]. These findings have demonstrated the integral role of Rybp at the early postimplantation and laterstage CNS development. Simultaneously, early embryonic lethality of the rybp homozygous null embryos were obstacles to the study of the precise role of Rybp at later developmental stages or the development of other organs.

In this study, the early lethal effect of Rybp deficiency was overcome by utilizing $r y b p^{-/-}$embryonic stem cells (ESCs) to model cardiac differentiation in the lack of Rybp. Our results showed that ESCs lacking functional Rybp are not able to form contractile cardiomyocytes (CMCs) and that Rybp is important for the proper expression of several key regulators of cardiac development. Recent data provide

\footnotetext{
${ }^{1}$ BioTalentum Ltd., Gödöllö, Hungary.

${ }^{2}$ Institute of Genetics, Biological Research Centre, Hungarian Academy of Sciences, Szeged, Hungary.

${ }^{3}$ Laboratory for Functional Genome Analysis (LAFUGA), Gene Center, LMU Munich, Munich, Germany.

${ }_{5}^{4}$ Department of Pharmacology and Pharmacotherapy, University of Szeged, Szeged, Hungary.

${ }^{5}$ MTA-SZTE Research Group of Cardiovascular Pharmacology, Szeged, Hungary.

${ }^{6}$ Institute of Biophysics, Biological Research Centre, Hungarian Academy of Sciences, Szeged, Hungary.

${ }^{7}$ Molecular Animal Biotechnology Laboratory, Szent Istvan University, Gödöllö, Hungary.
} 
the first evidence that Rybp is required for the formation of beating CMCs. This defines a novel role for Rybp in mammalian heart formation and has implications for the understanding of heart diseases.

\section{Materials and Methods}

\section{Experimental procedures}

All chemicals were purchased from Sigma-Aldrich and all the culture reagents were from Invitrogen Life Technologies, unless otherwise specified.

\section{Cell culture}

Mouse R1 [8] [hereafter mentioned as $r y b p^{+/+}$or wildtype (WT) ESCs] and rybp null [6] (hereafter mentioned as $r y b p^{-/-}$) ESCs were thawed on mitomycin C (MitC; SigmaAldrich) inactivated mouse embryonic fibroblast (MEF) layer and cultured on gelatin-coated tissue culture plates as described [9]. All cells were cultured at $37^{\circ} \mathrm{C}$ in a humidified atmosphere containing $5 \% \mathrm{CO}_{2}$. ESCs were cultured in ESC medium, consisting of Dulbecco's modified Eagle's medium GlutaMaxI, 15\% (v/v) ES cell qualified fetal calf serum (SLI Ltd.), $1 \%$ (v/v) nonessential amino acids, $1 \%$ (v/v) Pen/Strep, $100 \mu \mathrm{M}$ 2-mercaptoethanol, and 1,000 U/mL 1eukemia inhibitory factor (LIF, ESGRO; Chemicon/Millipore). Medium was changed daily on mouse ESC cultures and every 2 days during differentiation.

\section{Expression vectors}

To generate Rybp/Egfp expression constructs, we modified the original vector of Lois et al. to include a multiple cloning site and an IRES sequence upstream of the Egfp gene [10]. We cloned the Rybp cDNA to the multiple cloning site by the Xba1/Nhe1 digest. We also substituted the ubiquitin-C promoter by the promoter of the elongation factor- $1 \alpha(\mathrm{EF} 1 \alpha)$ gene.

\section{Production of lentiviruses}

All recombinant lentiviruses were produced by transient transfection of 293T cells, as described by Dull et al. [11]. The packaging constructs were obtained through Addgene (ref No: pMD2.G: 12259, pRSV-Rev: 12253, pMDLg/pRRE: 12251). The lentiviral particles were tested on $293 \mathrm{~T}$ cells.

\section{Transduction of ESCs}

Lentiviral particles were added to ESCs in expansion culture medium (MOI: 3-5) in the presence of $8 \mu \mathrm{g} / \mathrm{mL}$ polybrene and were centrifuged for $30 \mathrm{~min}$ on $1,000 \mathrm{~g}$ at $32^{\circ} \mathrm{C}$. After overnight incubation at $37^{\circ} \mathrm{C}$, the full medium was changed to fresh expansion medium. The cells were assayed 3 days after infection.

\section{Immunoblot analysis of ESCs}

Immunoblotting experiments of ESCs were carried out on $50 \mu \mathrm{g}$ protein from whole cell lysates fractionated by sodium dodecyl sulfate-polyacrylamide gel electrophoresis using secondary antibodies conjugated with horseradish peroxidase (HRP, AP132P; Millipore). The intensities of the reactive bands were detected by Bio-Rad Opti-4CN Substrate
Kit (170-8235). Anti-Rybp (anti-Dedaf 1:1,000, AB3637; Chemicon) was used for the detection of Rybp protein expression.

\section{Immunocytochemistry}

For immunofluorescence staining of the cells, cells were plated onto $0.1 \%$ gelatin-coated coverslips and fixed with 4\% paraformaldehyde (PFA) for $15 \mathrm{~min}$ at room temperature. Cells were permeabilized with $0.05 \%$ Triton-X-100/ phosphate-buffered saline (PBS) for $10 \mathrm{~min}$ at room temperature, followed by blocking in $1 \%$ bovine serum albumin for $1 \mathrm{~h}$ at room temperature. Cells were washed with PBS and incubated overnight with primary antibody at $4{ }^{\circ} \mathrm{C}$. Primary antibodies used for this study include Oct $3 / 4$ antibody (C-10, 1:100; Santa Cruz), anti-Rybp (anti-Dedaf 1:1,000, AB3637; Chemicon), and cardiac Troponin T antibody [Ms mAb Cardiac Troponin T (1C11) 1:2,000, ab8295; Abcam]. After washing thrice with PBS, cells were labeled with Alexa Fluor ${ }^{\circledR} 647$-conjugated secondary antibodies (for Oct3/4 antibody and for anti-Rybp; Invitrogen) and Alexa Fluor 488 Goat Anti-Mouse IgG $(\mathrm{H}+\mathrm{L})$ secondary antibody $(1: 2,000, \mathrm{~A} 11001$; Invitrogen) for $1 \mathrm{~h}$ at room temperature. Cells were then washed thrice with PBS and covered with DAPI mounting medium (VectaShield; Vector Laboratories). Imaging was performed with an Olympus $\mathrm{Ce}^{\circledR}{ }^{\circledR}$ Imaging microscope (Olympus Corporation) and with an Olympus LSM confocal microscope (Olympus Corporation). The captured images of immunocytochemistry (ICC) were semiquantified using Olympus FluoView software.

\section{Histology and immunohistochemistry}

Embryos and adult mouse testis were collected, washed thrice in PBS, fixed overnight with 4\% PFA, embedded in paraffin, and examined for general histological analysis. Serial sections were generated, and 4- $\mu \mathrm{m}$-thick sections were hematoxylin and eosin stained for morphology assessment and with anti-Rybp (anti-Dedaf 1:1,000, AB3637; Chemicon) for monitoring endogenous Rybp staining. The sections were analyzed and imaged by using a Zeiss AxioImager Z1 microscope (Carl Zeiss MicroImaging GmbH).

\section{mRNA expression analysis}

Total cellular RNA was isolated using the RNeasy Mini Kit (Qiagen) according to the manufacturer's instructions. The RNA prep was DNase treated (Promega), and transcribed by the Superscript II cDNA Synthesis Kit (Invitrogen, by Life Technologies), as per the manufacturer's instructions. Quantitative real-time polymerase chain reaction (RT-PCR) was performed in the SYBR Green JumpStart Taq ReadyMix (S4438) for the QPCR green master mix, in the Rotor-Gene Q real-time PCR machine (Qiagen). Gapdh was used as an internal control. Experiments were performed in triplicate and repeated at least twice. See primer sequences in Supplementary Table S1; Supplementary Data are available online at www.liebertpub.com/scd.

\section{In vitro cardiac differentiation}

For cardiac differentiation, embryoid bodies (EBs) were generated by the hanging-drop (HD) method as previously 
described [12]. For single-cell suspensions, the cells were dissociated from monolayer culture with $0.25 \%$ trypsinEDTA [day 0 (d0)]. The cells were counted, and 800 cells/ $20 \mu \mathrm{L}$ differentiation medium (ESC medium without LIF) were pipetted on the lid of a bacterial Petri-dish. The dish was filled with PBS to prevent the droplets from drying out. The cells were allowed to aggregate with the help of gravity by reversing the Petri-dish lid. On day 2, individual EBs were plated into a well of a 24 -well plate containing $0.1 \%$ gelatin-coated coverslips. Differentiation medium was changed every second day; the number of CMCs was continuously observed and recorded. The CMCs were further processed as required (eg, monitoring $\left[\mathrm{Ca}^{2+}\right]$ transient and cell contraction or mRNA expression analysis) or fixed on day 7 (d7), day 14 (d14), and day 21 (d21) for ICC.

\section{Quantification of beating activity of EBs}

Quantification of beating activity of EBs was performed as previously described $[13,14]$. In brief, the number of spontaneously beating clusters was recorded daily after plating EBs under a Nikon TMS inverted light microscope (Nikon Instruments, Inc.). The number of beating EBs was represented as the percentage of the total plated EBs. The cardiac beatings were further evaluated by grading of cardiac beating (area of cardiac beating and beating rate) as described earlier $[13,14]$. The results represent the mean \pm SEM of three independent experiments. Statistical analyses for a comparison of the percentage of the EB beating and the grading of EB beating between groups were conducted using a one-way ANOVA of SPSS Statistics version 18.0.

\section{Monitoring $\left[\mathrm{Ca}^{2+}\right]_{i}$ transient and cell contraction}

CMCs were loaded with $5 \mu \mathrm{M}$ Fluo-4 (Molecular Probes, Inc.), in DMSO $+20 \%$ pluronic acid F-127 (Sigma-Aldrich) in differentiation medium for $40 \mathrm{~min}$ in the dark at room temperature. Subsequently, myocytes were washed twice with normal Tyrode's solution and placed on the stage of an inverted fluorescent microscope (Eclipse TE2000; Nikon). The Tyrode's solution contained the following (in $\mathrm{mM}$ ): 144 $\mathrm{NaCl}, 0.4 \mathrm{NaH}_{2} \mathrm{PO}_{4}, 4 \mathrm{KCl}, 0.53 \mathrm{MgSO}_{4}, 1.8 \mathrm{CaCl}_{2}, 5.5$ glucose, and 5 HEPES, pH 7.4 with $\mathrm{NaOH}$. Fluo-4 was excited at $480 \mathrm{~nm}$; fluorescence emission was recorded at $535 \mathrm{~nm}$ by using appropriate filter sets (Chroma Technology). Optical signals were recorded by a photon counting photomultiplier module (H7828; Hamamatsu) and sampled at $1 \mathrm{kHz}$. Cell contraction was determined by a video edge detection system (VED-105; Crescent Electronics). Measurements were performed, and data were analyzed using the WinWCP software (V4.9.1. Whole Cell Electrophysiology Analysis Program, John Dempster, University of Strathclyde). All experiments were performed at room temperature.

\section{Global gene expression analysis by next-generation sequencing}

Cells from a $6 \mathrm{~cm}$ culture dish were harvested by resuspension in $500 \mu \mathrm{L}$ TRIzol (Invitrogen), and total RNA was extracted with the TRIzol method following the manufacturer's protocol. RNA was quality controlled by the nanodrop and bioanalyzer. High-quality RNA (RIN $>9$ and $260 / 230>2 ; 260 / 280>1.8)$ was converted to cDNA and
Illumina-compatible sequencing libraries using NuGEN Ovation and Encore NGS kits. Barcoded libraries were pooled and sequenced on an Illumina Genome Analyzer GAIIx in the single read mode with 80 nt read length. Reads were mapped to the mouse genome using TopHat [15]. Differentially expressed genes between wild-type and $r y b p^{-1-}$ ESCs were identified with DESeq and filtered for having a fold change $>1.5$ or $<-1.5$ and fdr $<0.05$. In the case of increasing gene expression, the fold change value was calculated by the expression ratio of the rybp ${ }^{-/-}$and the wild-type samples; however, when the gene expression showed a decreasing tendency, the negative reciprocal of this quotient was used for the fold change calculation. Significant genes were uploaded to the Ingenuity Pathway Analysis (IPA) (www.ingenuity.com) platform, where functional enrichment studies were executed. The extent of overrepresentation was quantified by the Benjamini-Hochberg corrected significance value that was calculated by using the Fisher's Exact test. Gene annotation information was either derived from the knowledge base of IPA or collected from the Ensembl database using the BioMart tool.

\section{Results}

\section{Rybp is abundantly expressed in the developing mouse heart}

To gain further support for the presence of Rybp in different organs besides CNS, we examined the distribution of rybp mRNAs by Northern blotting analysis using total RNA isolated from multiple mouse tissues. Our results demonstrated that the major $4.7 \mathrm{~kb}$ isoform of rybp is highly expressed in the heart and also in other mouse tissues (kidney, liver, skin, small intestine, thymus) (Fig. 1A). To confirm that Rybp is also present at the protein level in the developing mouse heart, we examined its expression pattern by utilizing anti-Rybp (anti-Dedaf) antibody on embryonic sections. Rybp was shown to be readily detectable in the developing heart from day 8.5 of embryonic development (E8.5) (Fig. 1B). Prominent Rybp expression persisted during all embryonic stages examined and Rybp marked differentiated cell types of the heart, suggesting its involvement in heart development and differentiation.

\section{rybp null ESCs do not form rhythmically beating CMCs}

Abundant expression of Rybp in the heart prompted us to investigate the role of Rybp in the regulation of cardiac lineage commitment. To investigate the function of Rybp during cardiac differentiation, we utilized rybp null $\left(r y b p^{-/-}\right)$ ESCs lacking functional Rybp protein product [6] (Fig. 1C). $R y b p^{-1-}$ ESCs are viable and display typical ES cell morphology when grown on an MEF monolayer, forming round and oval-shaped compact colonies, indistinguishable from those that formed by the wild-type cells [6] (Fig. 1D). We used the classic HD method to generate EBs as a common intermediate during the in vitro differentiation of pluripotent stem cells into CMCs (Fig. 2A and Materials and Methods). Differentiation in brief, to induce ESC differentiation LIF, was withdrawn from the culture medium and cells were kept as HDs $(800$ cells $/ 20 \mu \mathrm{L})$ to form EBs. Two days later, EBs were transferred into a suspension culture system. At d4 of 
A

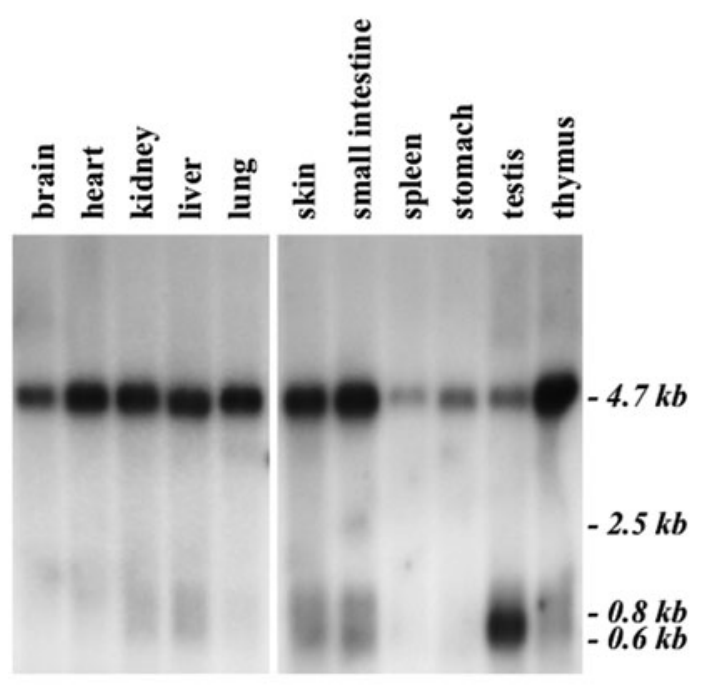

B

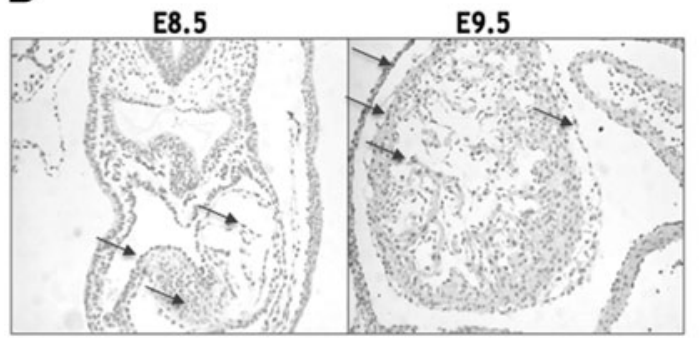

C
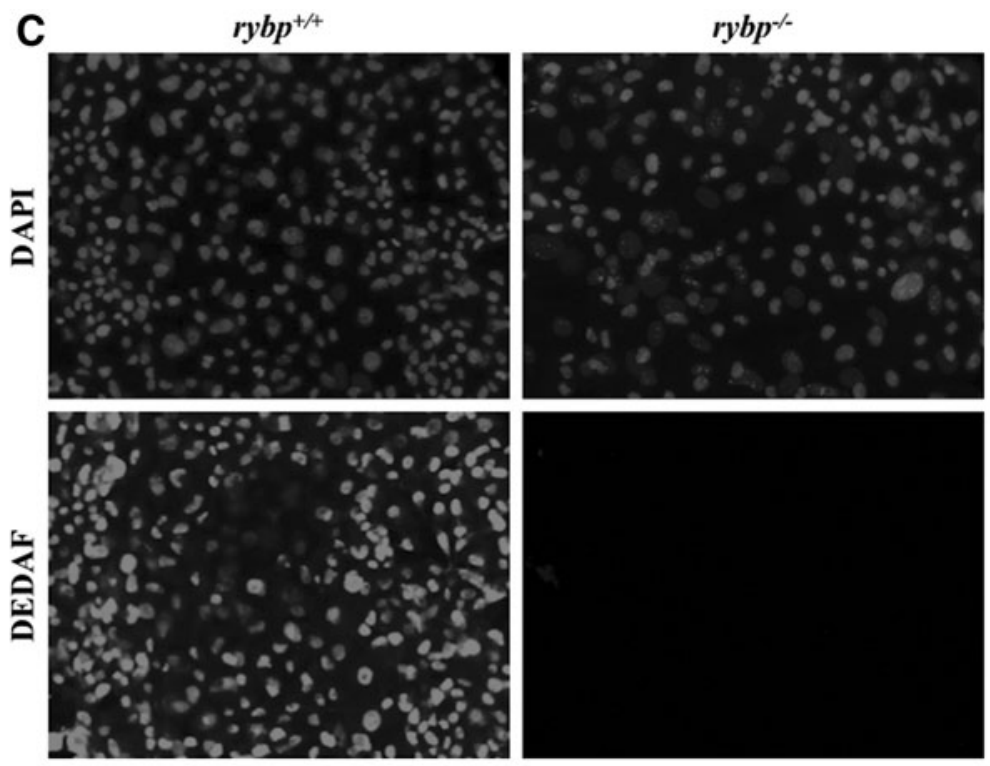

D

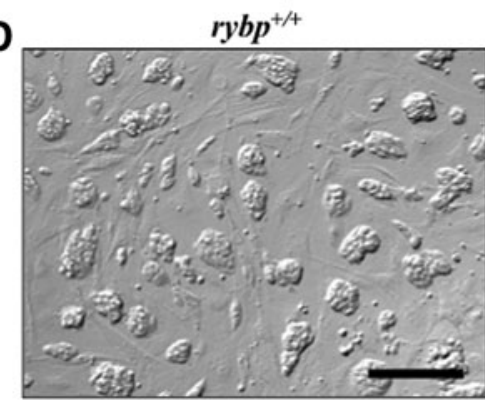

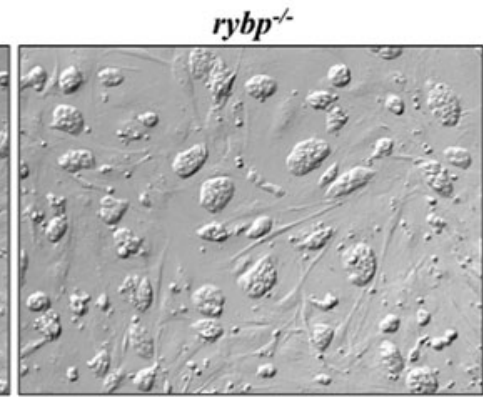

FIG. 1. Rybp is abundantly expressed in the embryonic and adult mouse heart. (A) Northern blot analysis with rybpspecific probe identifies a $4.7 \mathrm{~kb}$ major transcript in various mouse tissues and a $0.6 \mathrm{~kb}$ mRNA transcript expressed abundantly only in testis. Several rybp isoforms at lower-molecular-weight range $(0.6-0.8 \mathrm{~kb})$ are also visible in multiple tissues (kidney, liver, skin, small intestine thymus). The smallest molecular weight $0.6 \mathrm{~kb}$ isoform is not present in the heart and the brain. A $2.5 \mathrm{~kb}$ transcript is only present in the small intestine. (B) Representative examples of immunohistochemistry performed with an anti-Rybp (anti-Dedaf; Chemicon) antibody (dark gray staining, arrows) on counterstained (light gray) sections from early postimplantation developmental stages (E8.5; E9.5) in normal mouse embryos showing Rybp expression in the heart. (C) Immunostaining of wild-type $\left(r y b p^{+/+}\right)$and $r y b p^{-i-}$ ESCs for Rybp. ESCs were fixed and immunostained with anti-Dedaf antibody (light gray) and DAPI (dark gray). Rybp null ESCs are not expressing Rybp. Magnification: $20 \times$. (D) Bright field images of undifferentiated wild-type and rybp-null ESC colonies. Rybp null ESCs are viable and display a typical ES cell morphology. Colonies are composed of small cells attached to each other with a high N/C (nucleoplasm/cytoplasm) ratio where a single cytoplasm is not detectable. Based on gross morphology, the rybp ${ }^{-/-} \mathrm{ESCs}$ show the typical mouse ES cell morphology. Cells were grown on the MEF layer. Scale bar $=100 \mu \mathrm{m}$. ESCs, embryonic stem cells; MEF, mouse embryonic fibroblast; Rybp, Ring1 and Yy1 binding protein.

differentiation, the EBs were placed onto gelatin-coated coverslips, one of each of the coverslips, and they were grown for another 10 days. We subjected undifferentiated (d0) and differentiated ( $\mathrm{d} 8$ and $\mathrm{d} 14$ ) cell samples to analysis. Both WT and $r y b p^{-1-}$ ESCs formed EBs and attached to the gelatin-coated surface of the dishes, and WT ESCs formed rhythmically beating CMCs in 6-14 days (Fig. 2B). We found that although EBs could be derived from the rybp null ESCs no beating colonies were observed from the mutant cells (Fig. 2B). Out of 400 WT EBs, 93\% formed beating $\mathrm{CMCs}$ when they were allowed to attach on gelatin-coated surfaces by the 14th day of differentiation while none was beating from the $r y b p^{-/-}$genotype. Studies using Fluo-4 $\mathrm{Ca}^{2+}$-sensitive dye confirmed that $r y b p^{-1-} \mathrm{CMCs}$ cannot produce intracellular $\left[\mathrm{Ca}^{2+}\right]$ transient, indicating that the defective $\mathrm{Ca}$ handling may contribute to the loss of cell shortening (Fig. 2C). Analysis of gross morphology of derived $\mathrm{CMCs}$ showed decreased colony size and less cell content in the rybp null ESCs than the wild type at each examined timepoints of in vitro cardiac differentiation (Fig. 2D). This suggested that in vitro cardiac differentiation was affected by the absence of functional rybp.

\section{Ascorbic acid fails to induce contractility of the rybp ${ }^{-/-}$CMCs}

Ascorbic acid (ASC) is a known inducer of cardiac differentiation and robustly enhances cardiac differentiation of even cell lines without spontaneous cardiogenic potential. Therefore, we have added ASC supplement in the differentiation medium of the rybp null mutant cells to test whether their cardiogenic potential can be further increased in the 
A Hanging

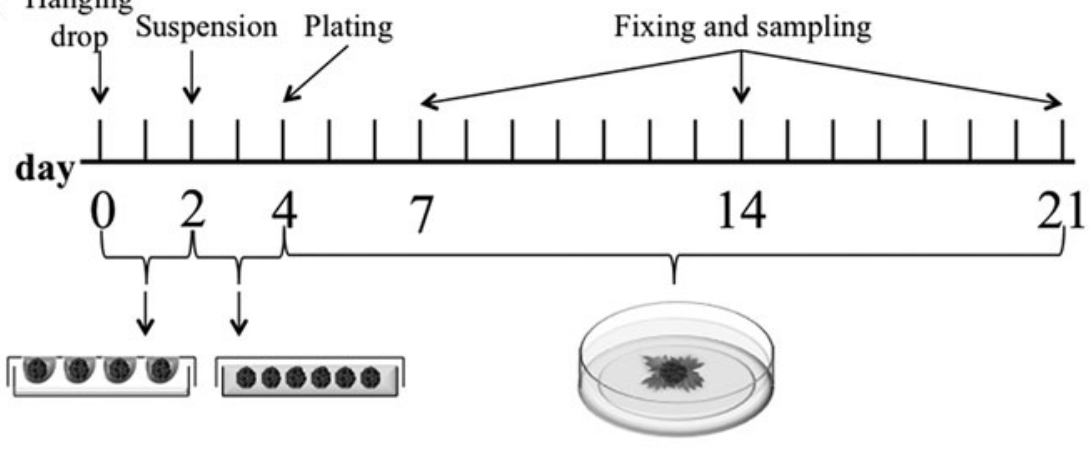

B
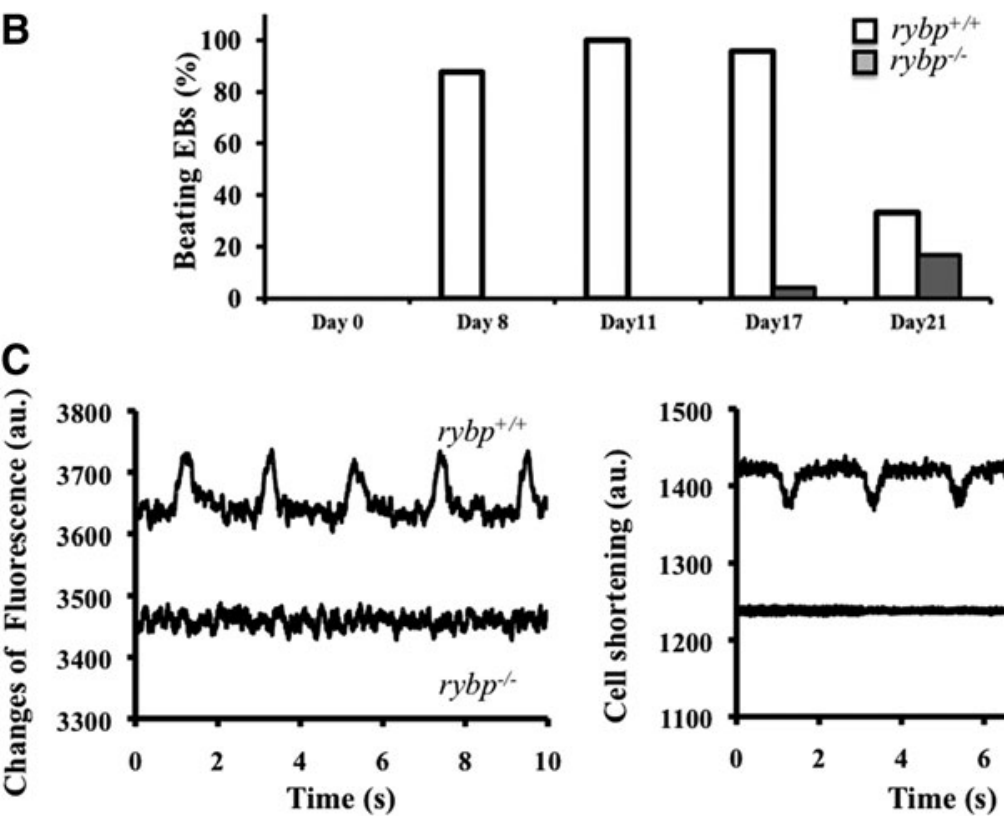

D

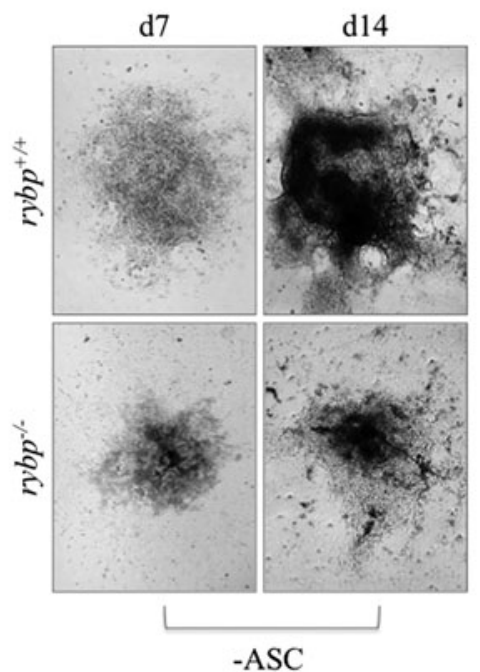

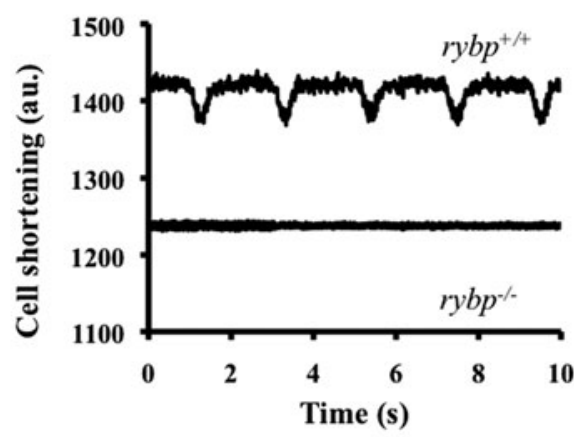

d7

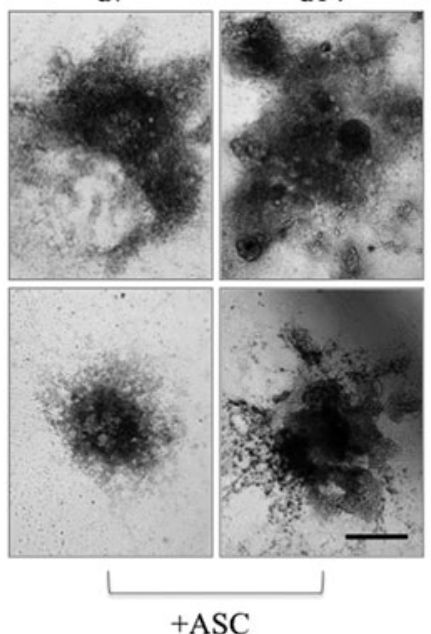

FIG. 2. The $r y b p^{+/+}$and $r y b p^{-/-}$ ESC lines show differences in morphology of differentiated CMC colonies and in contractile activity. (A) Schematic representation of in vitro cardiac differentiation. $\mathrm{CMCs}$ were differentiated in vitro from ESCs by using the hanging-drop method. CMC colonies were grown for 21 days and sampled at different time points (eg, day 0, 7, 14 and 21) as further required. (B) Quantitative analysis of beating $\mathrm{CMC}$ colonies derived from $r y b p^{+/+}$and $r y b p^{-/-}$ESCs. Vertical axis indicates the percentage of beating colonies; horizontal axis shows the days of observation (day 8, 11, 17 and 21). Day 0 corresponds to the undifferentiated ES cell stage (no beating). Ninety-three percent of $r y b p^{+++}$CMC colonies were beating from day 8 , and rybp ${ }^{-\prime-} \mathrm{CMC}$ colonies showed weak contractile activity only at day $17(\sim 5 \%)$ and day 21 ( 20\%). (C) Original recordings from 12 days old beating $r y b p^{+/+}$and nonbeating $r y b p^{-1-}$ CMCs derived from mouse ESCs. Left panel shows the changes of intracellular $\mathrm{Ca}^{2+}$ concentration as a $\mathrm{Ca}^{2+}$-dependent fluorescent signal (F535 nm). Right panel shows the corresponding cell shortening. (D) Comparison of $r y b p^{+/+}$and $r y b p^{-1-}$ CMC morphology with and without ASC treatment at day 7 and 14 shows prominent differences. The CMCs derived from WT $\left(r y b p^{+/+}\right)$ESC line had grown in multiple layers, while the mutant $\left(r y b p^{-/-}\right)$colonies were scattered and thin. CMCs derived from both ESC lines formed larger and more developed colonies with ASC induction. ASC, ascorbic acid; CMC, cardiomyocyte; WT, wild type. presence of ASC. We found that ASC was not able to induce the contractility of the $r y b p^{-1-}$ derivatives any further. However, as a result of the ASC treatment, cell populations from both genotypes grew and formed bigger colonies with visibly more cell layers than without ASC (Fig. 2D). This suggested that the rybp null mutant cells cannot form beating CMCs either spontaneously or after induction by ASC.
Lack of Rybp affects Is/1, Tnnt2, and Tbx3 expression in CMCs

To gain insights into underlying molecular events, we have measured the expression of lineage-specific markers in the $r y b p^{-1-}$ ESCs and compared them with the WT cells. We have also measured marker gene expression during the 
time course of cardiac differentiation $(\mathrm{d} 2,4,8,10,14)$ in both genotypes. Analysis revealed no significant changes in gene expression level of the key pluripotency genes (Rex1, Oct4, Nanog) (Fig. 3) and pan-mesodermal markers (T/Bra, Gsc) (Fig. 3). The expression of all examined pluripotency markers was progressively downregulated in both cell populations by differentiation. This suggested that silencing of pluripotency gene expression was properly executed in the $r y b p^{-1-}$ cells as well. Importantly, further gene expression analysis revealed downregulation of the terminal cardiogenic marker cardiac troponinT (Tnnt2) in the mutants, suggesting that cardiac lineage commitment was impaired in
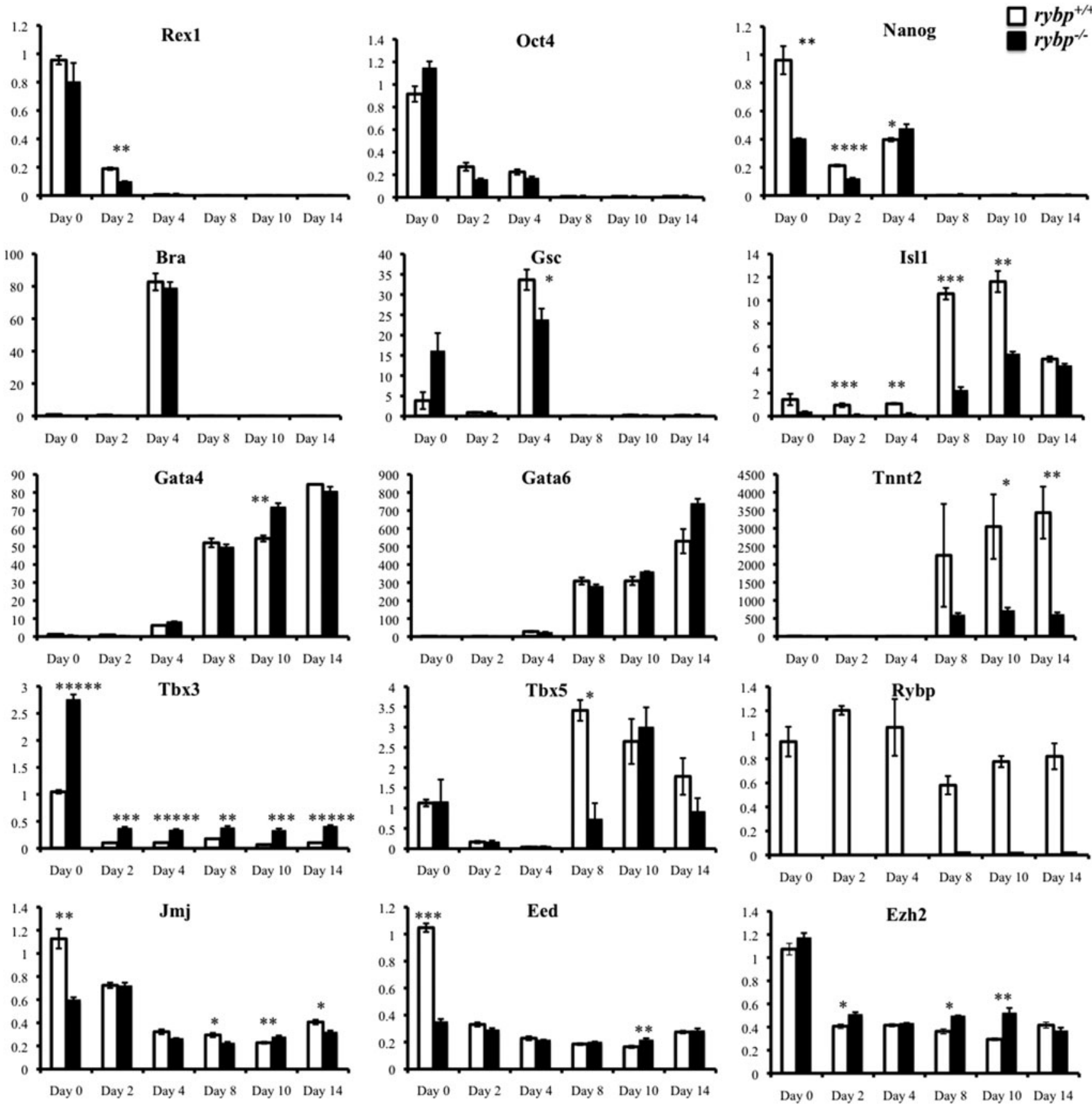

FIG. 3. $r y b p$-deficient ESCs are impaired in cardiac differentiation and expression of pluripotency (Rex1, Oct4, Nanog), early mesodermal (Bra, Gsc), early cardiac (Is11, Gata4, Gata6), T-box (Tbx3, Tbx5), and PcG (Jmj, Eed, Ezh2) genes during in vitro cardiac differentiation. For quantitative real-time polymerase chain reaction (RT-PCR) analyses, RNA was extracted, reverse transcribed from differentiated cardiac cells generated from WT and rybp ${ }^{-1-}$ ESCs at day $0,2,4,8,10$, and 14 of differentiation, and analyzed for expression of marker genes. Gapdh transcripts were amplified as an internal control. The expressions of the indicated markers were relative gene expression changes and were normalized to Gapdh expression. Quantitative RT-PCR was performed with the primers listed in Supplementary Table S1. Values and means: $\pm \mathrm{SD} * P<0.05$; $* * P<0.01$; $* * * P<0.001$; **** $P<0.0001$; ***** $P<0.00001(n=5)$ Statistical method: $t$-test type 3 . $\mathrm{PcG}$, polycomb group protein. 
the $r y b p^{-/-}$cells. By examining the earlier steps of cardiac lineage commitment (Isl1, Gata4, Gata6 expression), we found no significant differences in the expression of Gata4 and Gata6 expression (Fig. 3) while Isl1 expression was impaired in the mutants (near $6 \times$ more in the WT cells) (Fig. $3)$. Isl1 is a homeobox transcription factor and an essential regulator of cardiac progenitor differentiation. Rybp may function as a member of PRC1 [4,16] and regulate the expression of homeobox-type transcription factors during heart development. Therefore, we have also examined whether the expressions of the T-box (homeobox-type) cardiac transcription factors (Tbx3, Tbx5) were changed. CMCs lacking rybp showed more than a 2-fold increase in Tbx3 expression compared with WT (Fig. 3); however, the level of Tbx5 did not change significantly. Together, the data suggested that while expression of pluripotency genes was commonly downregulated, differentiation-driven activation of some cardiac transcription factors, such as the homeoboxtype Is11 and Tbx3, is different between cells expressing Rybp and those lacking Rybp.

Polycomb-repressive complex 2 (PRC2) regulates the balance between self-renewal and differentiation of ESCs. Therefore, we have examined whether loss of rybp results in the altered expression of PRC2 members. Our data showed no significant alterations in $\mathrm{PcG}$ expression levels, including Ezh2, Eed, and also PCR2 regulator Jmj. This suggests that lack of rybp (Fig. 3) has no significant influence on the expression level of the PRC2 members. These results also showed that Rybp is necessary for the proper execution of CMC differentiation.

\section{Transcriptome analysis reveals a spectrum of genes with altered expression profile in the rybp null ESCs and CMCs}

To examine possible gene expression alterations in a broader spectrum and to examine which signaling pathways are influenced by the lack of rybp, we have performed a quantitative comparative transcriptome analysis with the Illumina genome analyzer. We have compared the gene expression profile of the undifferentiated $r y b p^{-/-}$and WT ESCs (d0). We also performed analysis on differentiated ESCs (d8, d14). D8 represents an earlier time point and d14 corresponds to a later time point of in vitro cardiac differentiation and lineage commitment. Using the filtering criteria of a two-or-greater fold change in expression and a false discovery rate of less than $1 \%, 53$ out of more than 20747 transcripts were differentially expressed at the undifferentiated stage (d0) (Table 1). At the differentiated stage $3 \%, 716$ out of more than 23045 transcripts were at $\mathrm{d} 8$ (early stage) (Table 1) and $3.5 \%, 768$ out of more than

Table 1. Gene Expression Changes in $R Y B P^{-/-}$Cells

\begin{tabular}{lccc}
\hline & $\begin{array}{c}\text { Significant } \\
\text { increase }\end{array}$ & $\begin{array}{c}\text { Significant } \\
\text { decrease }\end{array}$ & $\begin{array}{c}\text { Genes } \\
\text { detected }\end{array}$ \\
\hline d0 & 24 & 29 & 20747 \\
d8 & 392 & 324 & 23045 \\
d14 & 477 & 291 & 21982 \\
\hline
\end{tabular}

d, day.
21982 transcripts were at d14 (late stage) (Table 1). Under these conditions, there were 25 transcripts with increased expression in the rybp null ESCs (d0), while 30 transcripts showed decreased expression (Supplementary Tables S2 and S3). There were 393 transcripts with increased expression in the rybp null ESCs at d8, while 325 transcripts showed decreased expression (Supplementary Tables S2 and S3). At d14 of cardiac differentiation, 478 transcripts showed increased expression and 292 showed decreased expression (Supplementary Tables S2 and S3). To identify the biological processes in which genes transcriptionally affected in $r y b p^{-/-}$ESCs are involved, we performed gene function enrichment analysis using the IPA knowledge base. At the undifferentiated stage (d0), ESCs displayed the most striking effect that was recorded in genes that were critical for germ development. The transcriptome analysis revealed that genes critical for germ development were de-repressed in comparison to the WT ESCs (eg, Tex11, Tex13, Piwil2, Dazl, Rnf17) (Supplementary Tables S2 and S3). These genes are involved in the early stage of spermatogenesis and are also expressed in primordial germ cells. Immunostaining of adult testis confirmed that Rybp was localized in spermatogonia and weak staining of spermatocytes, but it was not visible in spermatids or Sertoli or Leydig cells (Supplementary Fig. S1). The transcriptome analysis of $\mathrm{d} 8$ and d14 differentiated cells showed that other genes, involved in the later stage of sperm development, are also de-repressed (eg, Ddx4, Mael, Syce1, Sycp3). The IPA analysis revealed a significant enrichment in different Gene Ontology Biological Process categories, such as apoptosis (d8: Supplementary Table S4; d14 Supplementary Table S5) in which $r y b p$ is already known to be involved $[17,18]$. This observation suggests that $r y b p$ deficiency has an effect on the transcriptome in ESCs, which is consistent with the data obtained.

\section{Altered expression level of genes important for cardiovascular system development and function in the rybp-deficient CMCs}

To better understand the precise role of rybp in heart development, we conducted functional enrichment assay using IPA. The IPA analyses revealed that several cardiovascular-related gene sets can be found among most overrepresented physiological functions in the rybp-deficient samples during cardiac differentiation (d8: Fig. 4A, day 14: Fig. 4B). Genes of this functional category with significantly different expression in WT and $r y b p^{-/-}$ESCs are listed in Supplementary Table S6 (d8) and Supplementary Table S7 (d14). Given these data, which provided additional evidence that absence of rybp has an effect on the transcriptome in ESCs and CMCs, we further analyzed the data obtained by DNA-seq and searched for genes expressed in the heart and for genes already known to have a cardiac phenotype in mouse models. One of the most downregulated genes expressed during cardiac differentiation is Plagl1 (d0: $\mathrm{FC}=$ $-13.86, \operatorname{padj}=2.3 \times 10^{-5} ; \mathrm{d} 8: \mathrm{FC}=-76.79, \operatorname{padj}=3.44 \times$ $10^{-77} ; \mathrm{d} 14: \mathrm{FC}=-92.91$, padj $=2.68 \times 10^{-79}$; Supplementary Table S3). Plagl1 is an essential factor for cardiac morphogenesis and is highly expressed in mouse hearts from E8.5 to adulthood in a chamber-restricted pattern. In the rybp null ESCs, Plagl1 is nearly absent at all timepoints of 

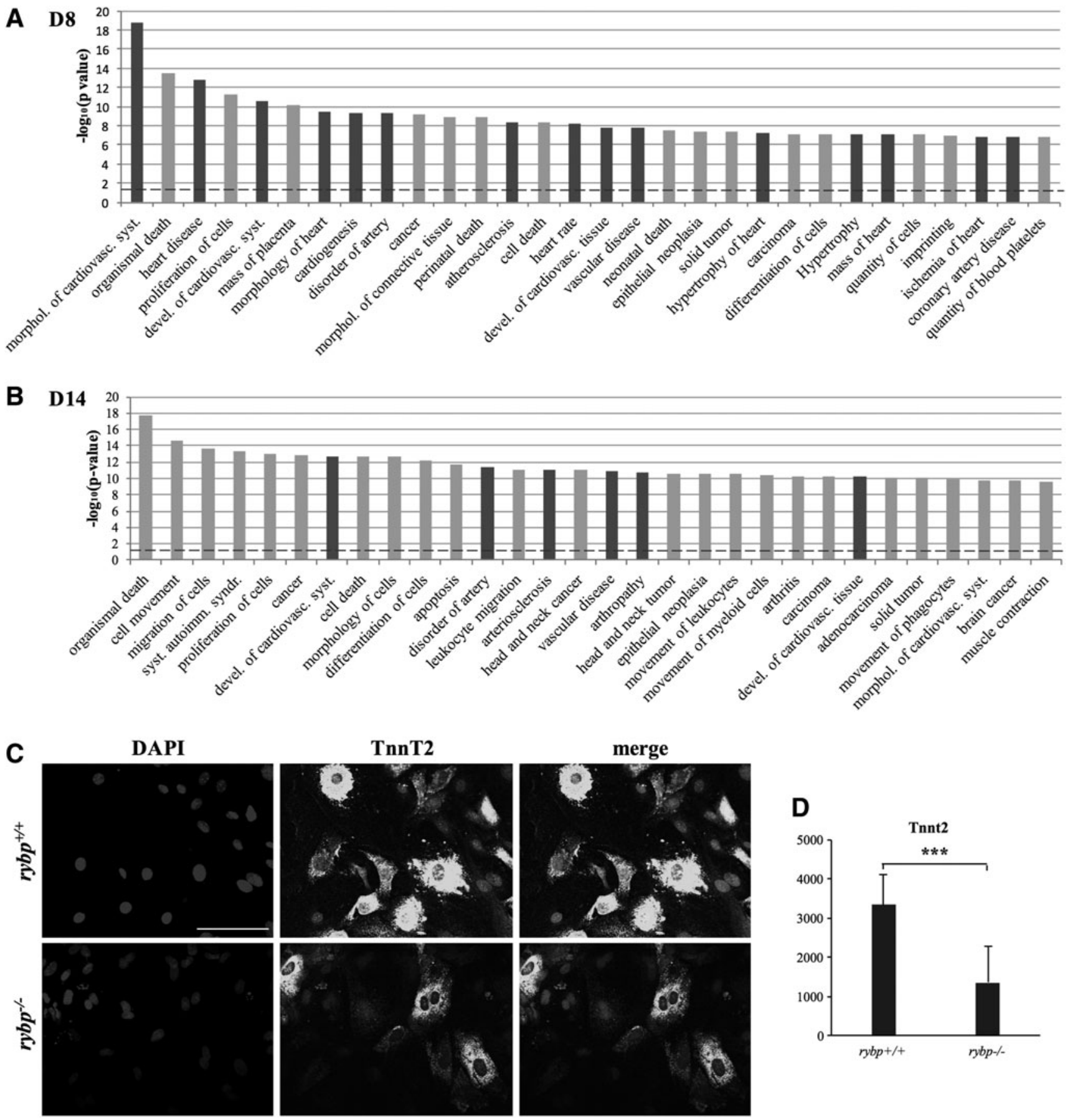

FIG. 4. (A-B) Functional categories overrepresented among genes with significantly different expression in WT and $r y b p^{-1-}$ ESCs. Vertical axis indicates the negative $\log _{10}$ transformed significance value of the enrichment calculated by Fisher's Exact Test. The horizontal (intermitted) line shows the $P=0.05$ threshold generally accepted as the criterion for the selection of significant enrichments. (A): samples from day 8. (B): samples from day 14. (C) Immunocytochemical localization of the cardiac Tnnt 2 protein (light gray) in $r y b p^{+/+}$and $r y b p^{-/-}$CMCs. Immunofluorescence analysis of CMCs derived from wild-type $\left(r y b p^{+/+}\right)$and null mutant $\left(r y b p^{-/-}\right)$ESCs at day 21 of differentiation using an anti-cardiac troponin $\mathrm{T}$ antibody reveals downregulation of cardiac troponinT (Tnnt2) in the mutants. Scale bar: $100 \mu \mathrm{m}$; Objective: $20 \times$. (D) Semi-quantification of Tnnt2 levels of $(\mathbf{C})$ by using Olympus FluoView software. Means are standard deviation \pm SD. Values of $P<0.05$ were accepted as significant $(* * * P<0.001)$. Statistical method: $t$-test type 3.

cardiac differentiation. On the contrary, one of the most upregulated gene during cardiac differentiation was Tbx3 $\left(\mathrm{d} 0: \mathrm{FC}=4.63\right.$, padj $=5.95 \times 10^{-3} ; \mathrm{d} 8: \mathrm{FC}=3.07$, padj $=$ $5.53 \times 10^{-7} ; \mathrm{d} 14: \mathrm{FC}=3.53$, padj $=2.11 \times 10^{-6}$ Supplementary Table S2), which is required for pacemaker and conduction system development in the mammalian heart. Tbx3 was present nearly $5 \times$ higher in the rybp mutants ESCs compared with the WT (d0) and was induced nearly $4 \times$ and $5 \times$ more in CMCs during cardiac differentiation. Six 1, which functions in cardiac progenitor cells but is 
stably silenced on cardiac differentiation, was also underrepresented in the rybp null ESCs (d0) and CMCs (d8; d14) $\left(\mathrm{d} 0: \mathrm{FC}=75.00\right.$, padj $=1.74 \times 10^{-2} ; \mathrm{d} 8: \mathrm{FC}=-5.23$, padj $=$ $5.73 \times 10^{-1} ; \mathrm{d} 14: \mathrm{FC}=-2.45$, padj $=9.48 \times 10^{-1}$ ) [19]. Our DNA-Seq data indicate that key cardiac differentiation pathways are impaired in the rybp null cells. This suggested that altered Rybp dosage led to the improper execution of the cardiac developmental program.

\section{Rybp-deficient ESCs do not express structural genes that are essential for contractility of matured CMSc}

The observation that rybp ${ }^{-/-}$CMCs cannot form rhythmically beating CMCs motivated us to perform gene function enrichment analysis using the IPA knowledge base and to examine the expression level of genes that are important for CMC contractility. IPA analysis revealed that rybp ${ }^{-1-}$ CMCs have an almost complete lack of organized myofibrils and Z-line genes (eg, Actn1, Myh6, Myh7, Myl2, Myl3, Myl4, Myod, Myom1, Tnni1, Tnni2, Tnni3, Tnnt2) when compared with normal WT CMCs (Supplementary Table S8). Among these genes, Tnnt2 is a key component of the troponin complex in CMCs. It has a regulatory role in $\mathrm{CMC}$ contraction by anchoring troponinI and troponinC to tropomyosin on the thin filaments in the sarcomeres and also confers a $\mathrm{Ca}^{2+}$ dependence on sarcomere contraction. Since the $r y b p^{-/-}$CMCs exhibit deficiency in terminal differentiation marker Tnnt 2 mRNA induction, we analyzed the spatial distribution of the Tnnt 2 protein product as well (Fig. 4C). Immunostaining of late-stage CMCs (d21) confirmed that cardiac Tnnt2 is localized in the cytoplasm and exhibits strong staining in the wild-type $\mathrm{CMCs}$ and its presence is less prominent in the rybp ${ }^{-/-}$cells (Fig. 4C, D). These data demonstrate that the absence of Rybp interferes with the normal expression of structural genes that are important for contractility, and it may have an important role in regulating $\mathrm{CMC}$ contraction and heartbeat.

\section{Rybp-deficient ESCs can be partially rescued by ectopic rybp}

Having shown that lack of rybp led to an impaired differentiation and interferes with CMC contractility, we assessed whether ectopic expression of Rybp might rescue the cardiac phenotype (no rhythmically contracting CMCs, impaired cardiac gene expression profile) of the $r y b p^{-/-}$ cells. We have postulated that by re-introducing rybp with a lentiviral expression vector (rescued cells; $r y b p^{\text {Res }}$ ) we can possibly induce contraction and restore the gene expression profile in the rescued cells (Fig. 2C).

We re-introduced the rybp cDNA in the $r y b p^{-/-}$ESCs by the lentiviral expression system (Fig. 5A). To this purpose, we generated stable ESC clones expressing the HA-tagged $r y b p$ cDNA in $r y b p^{-/-}$ESCs ( $r y b p^{\text {Res }}$ ESC lines) and tested for Rybp expression by immunohistochemistry (Fig. 5D) and western blotting (Fig. 5B). Lower Rybp expression was detected in the rybp ${ }^{\text {Res }}$ lines compared with WT ESCs by western blot analysis. To see whether this lower protein expression was due to the insufficiency of our lentiviral expression system, we performed quantitative RT-PCR analysis of $r y b p$ mRNA in the $r y b p^{\text {Res }}$ lines. We found 1015 times higher expression of $r y b p$ mRNA in the $r y b p^{\text {Res }}$ lines compared with WT ESCs (Fig. 5C).

To determine whether this level of Rypb was functional, both $r y b p^{-1-}$ and two independent rescued ESC lines $\left(r y b p^{\text {Res1 }} ; r y b p^{\text {Res2 }}\right)$ were allowed to differentiate toward CMCs. As the results showed, increased spontaneous beating activity in 20\%-25\% of the rescued CMCs (rybp ${ }^{\text {Res } 1 \text {; }}$ $r y b p^{\text {Res2 }}$ ) was observed (Fig. 5E). Microscopic observations revealed an increased cellularity in the $r y b p^{\text {Res }}$ clones compared with the parental $r y b p^{-/-}$cells (Fig. 5F). Molecular analysis of the gene expression profile confirmed that ectopic Rybp was able to partially rescue the cardiac defect: Is11, Tnnti3, and Myh6 expression was partially restored (Fig. 5G). Furthermore, germ line-specific Tex11, Ddx4, and Piwil2 expression was downregulated in $r y b p^{\text {Res }}$ lines, suggesting that Rybp is a repressor of germ-specific genes and absence of Rybp leads to activation of these promoters. This experiment also showed that a normal dosage of Rybp is required for both activation (some of the cardiac) and repression (germ specific) of target genes.

\section{Discussion}

We have previously shown the correct dose of Rybp required for maintaining the appropriate spatiotemporal expression pattern and levels of Rybp for proper CNS development, thereby providing an in vivo mouse model of NTDs [6]. In this study, we provided evidence for the expression of Rybp during mouse heart development and analyzed the consequences of the loss of rybp on in vitro cardiac differentiation. We found that homozygous rybpdeficient ESCs formed cell clusters but were not able to differentiate into rhythmically beating CMCs in vitro, suggesting the requirement of rybp for proper cardiac differentiation and contractility. Gene expression analysis of undifferentiated ESCs and CMCs during cardiac differentiation

FIG. 5. Reconstitution of Rybp expression and function in $r y b p^{-1-}$ ESCs. (A) Lentiviral construct used for ectopic expression of Rybp. (B) Western blot analysis of WT, rybp ${ }^{-1-}$, and two independent rescued ESC lines $\left(r y b p^{\text {Resl }}\right.$; rybp ${ }^{\text {Res2 } 2}$ ). Western blot was probed with anti-Dedaf antibody $(38 \mathrm{kDa})$. (C) Quantitative RT-PCR analysis of $r y b p^{\text {Res }}$ clones compared with WT cells. (D) Immunostaining of WT, rybp ${ }^{-}$, and rybp Res ESC clones for Rybp expression. ESCs were fixed and immunostained with anti-Dedaf antibody. (E) Spontaneous beating activity of differentiated WT, $r y b p^{-1-}$, and rescued ESC lines $\left(r y b p^{\text {Res } 1} ; r y b p^{\text {Res2 }}\right)$. Beating of differentiated EBs was counted at day 0, 8, and 11 of differentiation. (F) Microscopic analysis of cellularity of differentiated WT, rybp ${ }^{-1-}$, and rescued ESC lines (rybp ${ }^{\text {Res1 }}$; rybp ${ }^{\text {Res2 }}$ ). (G) Quantitative RT-PCR analysis of cardiac- and germ cell-specific differentiation markers. RNA was extracted, reverse transcribed from differentiated cardiac cells generated from WT, rybp $p^{-1-}$, and rescued ESC lines $\left(r y b p^{\text {ResI }} ; r^{2 y b p^{R e s 2}}\right)$ at day $0,4,8$, and 14 of differentiation, and analyzed for expression of differentiation markers Is11, Tnni3, Myh6, Tex11, Ddx4, and Piwil2. Gapdh transcripts were amplified as an internal control. Values and means: \pm SD $* P<0.05 ; * * P<0.01 ; * * * P<0.001$; $* * * * P<0.0001 ;(n=5)$ Statistical method: $t$-test type 3 . EBs, embryoid bodies. 
demonstrated upregulation (Tbx3) and downregulation of several transcription factors (Is11, Plagl1) and structural myofibril proteins (Actn1, Myh6, Myh7, Myl2, Myl3, Myl4, Myocd, Myom1, Tnni1, Tnni2, Tnni3, Tnnt2) that are critical for heart development.

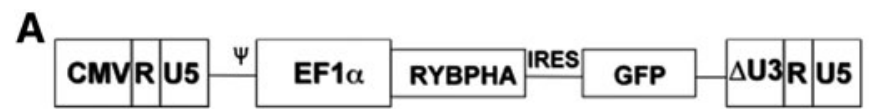

B

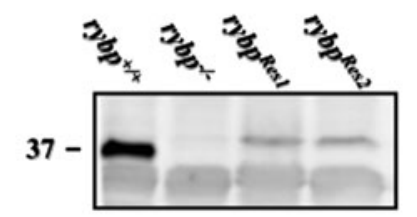

C
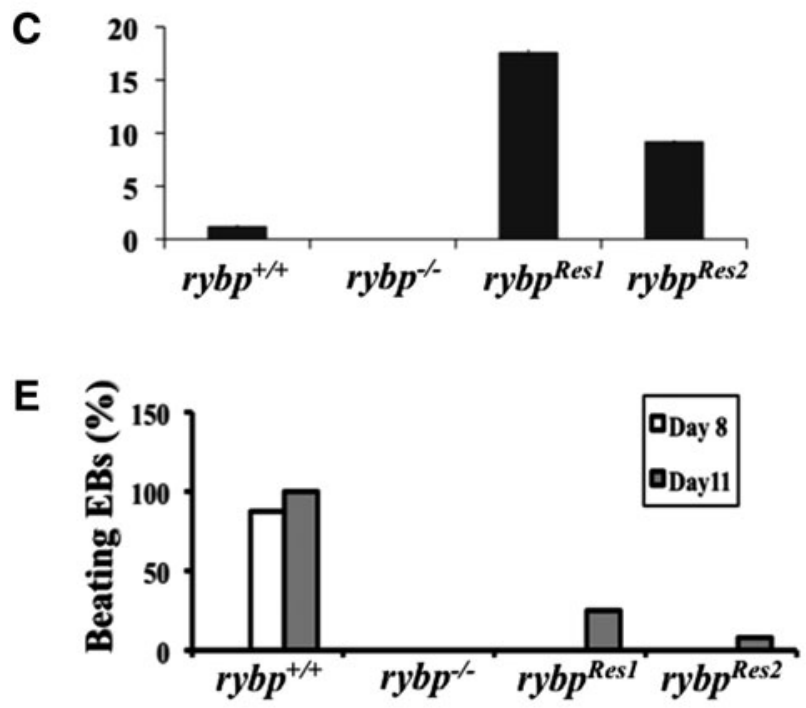

Aiming at finding the causatives of the observed phenotype, we have analyzed whether an alteration in pluripotency, or key developmental and cardiac gene expression is responsible for the impairment. One possible explanation for the impaired cardiac differentiation of the mutants is that
D
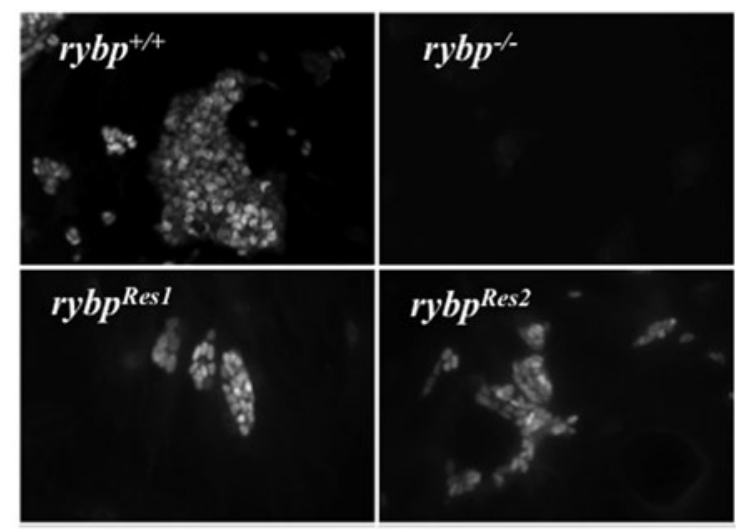

$\mathbf{F}$

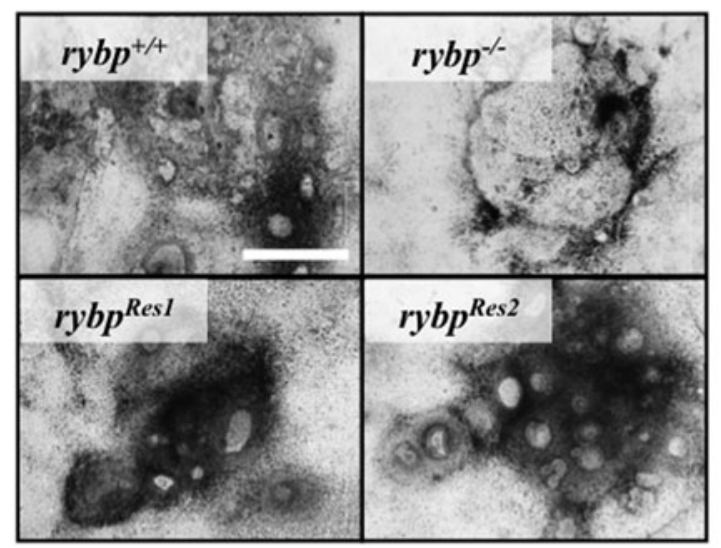

\section{G}
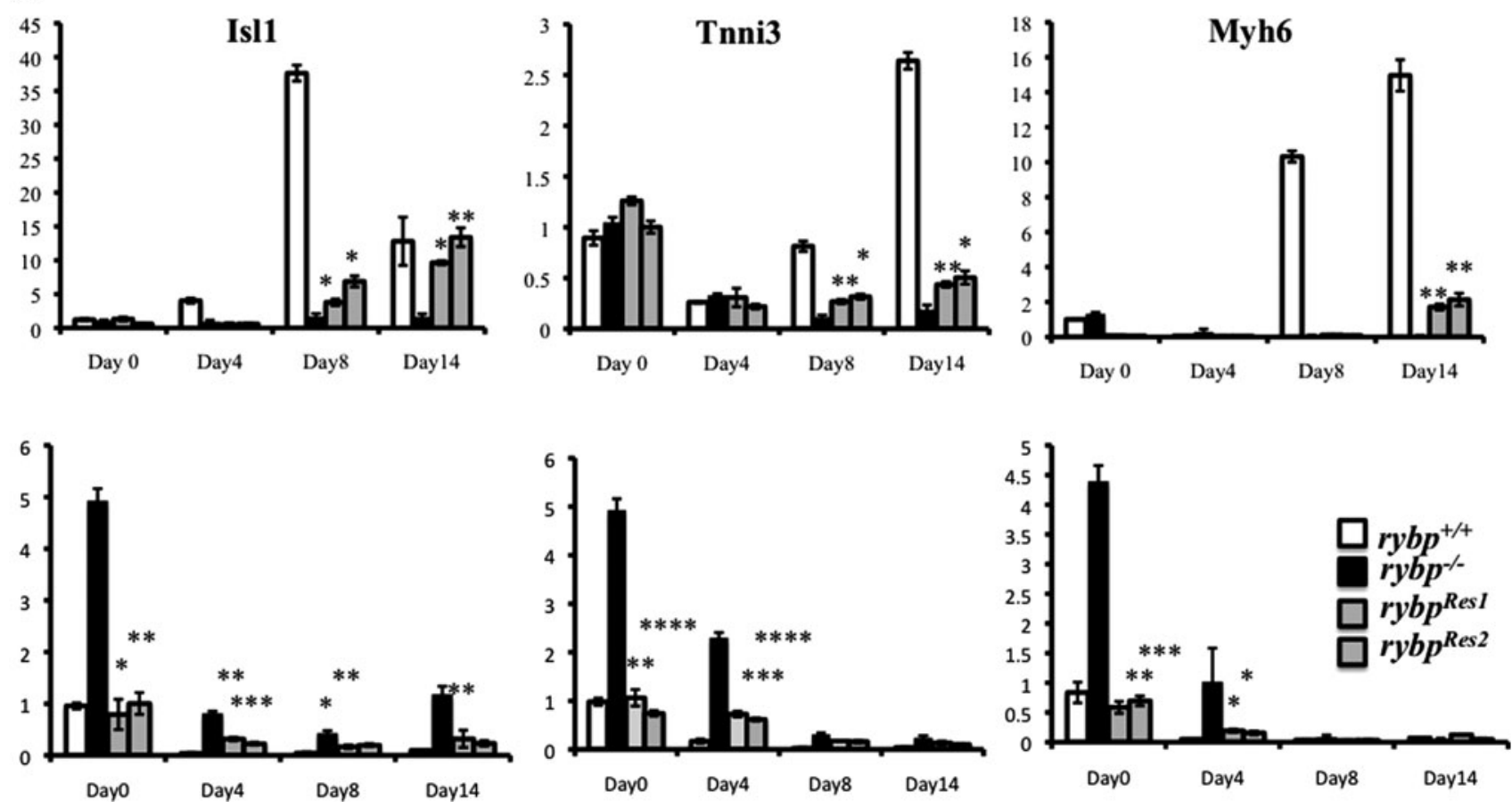
pluripotency gene silencing is incomplete during differentiation, which may cause impaired differentiation. First, we analyzed the key pluripotency gene (eg, Rex1, Oct4, Nanog) expression levels and we concluded that there were no significant changes in the kinetics of pluripotency gene expression between the two cell populations ( $r y b p^{-/-}$vs. $\left.r y b p^{+/+}\right)$. We concluded that proper silencing of pluripotency genes shows the expected kinetics, thus it cannot be the causative of the observed differentiation defect.

Second, since the mammalian heart essentially has a mesodermal origin, we have tested whether the mesoderm is properly formed in the rybp mutant cells. We did not find a difference in the expression pattern of the pan-mesodermal marker Bra/T, which, as expected, was nearly absent in the undifferentiated ESCs and transiently expressed during EB formation peaking at $\mathrm{d} 4$. Gsc, which is another marker or early mesodermal lineage commitment, exhibited normal expression pattern in the rybp mutants as well. Notably, the level of Gsc transcripts was 3-fold higher in the undifferentiated $r y b p^{-/-}$than in the wild-type ESCs, suggesting that an abundant pool of mesodermal precursors is available in the $r y b p^{-/-}$cells at the beginning of cardiac differentiation. Taken together, these data showed that silencing of pluripotency gene expression and formation of mesoderm were comparable in both the WT and the rybp null mutant cells and that the defect in cardiac differentiation is probably due to later-stage causatives. By examining the induction kinetic of several key cardiac transcription factors, we have found that induction of Isl1 expression was defective in the rybp $^{-/-}$cells $(10 \times$ vs. $2 \times$ by d $8 ; 12 \times$ vs. $5 \times$ by d10) (Fig. $3)$. Isl1 is an essential regulator of cardiac progenitor differentiation and also an important transcriptional factor for the development of the secondary heart field. Thus, one possible explanation for the phenotype is that deficiency in Isl1 expression leads to improper cardiac progenitor cell differentiation and these resulted in defects in producing functional CMCs in the $r y b p^{-/-}$mutants. It is also worthwhile to note that Isl1 belongs to the family of homeodomain transcriptional regulators, thus it can be a potential target of Rybp by a PcG-dependent fashion. PcG proteins regulate homeotic gene expression and are essential for organ development. It had been previously shown that members of the PRC1 and PRC2 complexes have essential roles in early embryonic development; however, few of their target genes are known in mammals $[20,21]$. Some of the PcG proteins were also shown to have an essential function in mammalian heart development. A key cardiac regulatory gene, six 1 , which also has altered expression in the $r y b p^{-\gamma-} \mathrm{CMCs}$, is suppressed by a PcGmediated mechanism by PRC2 member Ezh2 and Eed in cardiac differentiation [22]. Loss of Ezh2 in cardiac progenitors and in CMCs mediated by early myocardial transcription factor $\mathrm{Nkx} 2.5^{\mathrm{Cre}}$ resulted in lethal heart abnormalities and disrupted CMC gene expression. PRC1 member Rae28 knockout mice displayed cardiac anomalies similar to congenital heart diseases in humans [23]. Rae28 sustains Nkx2.5 expression in CMCs and plays a key role in cardiac lineage commitment [24]. Furthermore, in ES cell-based assays, the loss of function of the Rybp binding partner Yy1 resulted in a decrease in CMCs, whereas Yy1 gain of function enhanced the generation of cardiac cells [25]. As far as the potential role of Rybp in PRC-mediated repression is concerned, we still do not have a clear understanding of how Rybp functions as a PRC member or how PcG complexes containing Rybp reach their targets. Rybp is generally considered a PcG protein and a transcriptional repressor [5,26], so downregulation of downstream targets that results from the absence of rybp seems paradoxical. This leads to two alternate possibilities. Either Rybp normally represses factors that would otherwise repress the target genes (absence of a putative repressor results in the downregulation of downstream targets), or Rybp functions as a transcriptional activator on some genes. In the first case, we would expect that the repressive function of Rybp is typical of a PRC1 complex-dependent regulation. In the second case, activation by Rybp would most likely be independent of PcG proteins although it is also possible that Rybp specifically displaces PRC1 from chromatin and facilitates transcriptional activation in this manner [27]. By the biochemical characterization of Rybp Containing Multimeric Protein Complexes, much of which should also contain Ring1 or Yyl proteins, this paradox might be easier to solve.

On the other hand, lack of Rybp did not result in a significant change in the expression level of some other homeodomain transcription factors. The level of Tbx5, which is an essential gene of mammalian heart development, did not change in our experiments, suggesting that Rybp regulates cardiac transcription factors via different regulatory circuits. It has also been reported that Rybp is functioning as member of the noncanonical PRC1 complex in a broad variety of target genes [4]. Rybp, as a member of the noncanonical PRC, has an emerging and complex role in the regulation of gene expression, differentiation, and development. Furthermore, Rybp defines functionally different PRC1 family complexes, thus preventing the incorporation of other canonical PRC1 subunits, such as $\mathrm{Cbx}, \mathrm{Scm}$, and Phc. The precise biological functions of these versatile complexes are not known [4]. To clarify whether Rybp is functioning as a member of the PRC1 complexes during heart development certainly needs further investigations. Notably, transcriptome analysis did not show any disturbance in PcG protein distribution between the undifferentiated $r y b p^{-1-}$ and WT ESCs or CMCs (Supplementary Tables S2 and S3). This suggests that the lack of functional Rybp had no significant effect on the expression of the PRC1 and PRC2 members.

Downregulation of terminal cardiac marker Tnnt 2 in the $r y b p^{-1-}$ CMCs may indicate the role of Rybp in regulating structural proteins of the functional sarcomer. Lack of Tnnt2 in mouse models caused early embryonic lethality due to a lack of heartbeats [28]. Our gene expression analysis showed decreased expression of Tnnt 2 in the rybp null mutants $(\sim 2,000 \times$ vs. $500 \times$ by d8; $3,000 \times$ vs. $500 \times$ by d 10 and $3,500 \times$ vs. $500 \times$ by d14); however, it was still abundantly expressed even in the rybp ${ }^{-1-}$ mutant CMCs $(500 \times)$ compared with the WT CMCs (Fig. 3). This suggests that perhaps not only the availability but also the functionality of Tnnt2 is critical for the contraction of the WT CMCs. Members of PRC2 are also required later in heart development, as demonstrated by the conditional TNT-Cre inactivated Eed knockout mice. However, Ezh2 inactivation (another essential member of PRC2) by TNT-Cre did not cause an overt phenotype, likely because of functional 
redundancy with Ezh1 [22]. Further experiments need to clarify whether the assembly of functional sarcomeres is impaired in the rybp mutants.

Our recent study also showed that the defect in contractility in the rybp null CMCs could not be restored by adding ASC to the culture as a supplement. ASC has multiple effects on cell proliferation and differentiation, especially of promoting mesenchymal cells toward adipogenesis, osteogenesis, chondrogenesis, and myogenesis. ASC is also able to restore the contractile response in patients after heart failure or myocardial infarction [29]. However, in our experiments, ASC was not able to restore contractility of the mutant CMCs but increased the cell mass of the $r y b p^{-/-}$and $r y b p^{+/+}$CMCs. Little is known about the exact effect of ASC, but it has been reported that reactive oxygen species (ROS) regulate the intracellular signal transduction of the $\beta$ adrenergic pathway, that is, its receptors, G-proteins and adenylyl cyclase, function in the myocardium [30]. These observations have led to the hypothesis that ROS directly affect myocardial contractile function through alteration of the $\beta$-adrenergic pathway. Future experiments need to clarify whether members of the $\beta$-adrenergic pathway are defective in the rybp ${ }^{-1-}$ CMCs.

Importantly, re-introduction of rybp by a lentiviral expression vector in rybp deficient ESCs was able to rescue the mutant phenotype and has partially restored contractility of the $r y b p^{-/-}$CMCs. The appearance of contracting cells was paralleled by the expression of early (Isl1) and late (Tnni3) cardiac gene markers, thus suggesting their identity as CMCs.

It is also important to mention that the absence of functional Rybp had a significant effect on the cascade members of germ cell development. This is in agreement with the abundant expression of Rybp in the reproductive systems and the recent observation of Hisada et al., that Rybp functions as a de-repressor of germ specific genes in pluripotent ESCs [31]. Our transcriptome analysis revealed that abundant expression of germ line-specific genes persists during the entire course of in vitro cardiac differentiation and their downregulation is impaired. Our experiments demonstrated that abundant germ line-specific gene expression persists during the entire time course of cardiac differentiation in the mutants. Therefore, we cannot rule out the possible effect of this abundant germ-specific gene expression on the inhibition of normal somatic differentiation (eg, cardiac), which needs further investigation. Especially, recent evidence indicates that germ line-specific genes [eg, vasa (Ddx4), stella (Dppa3)] also function in other cell types, distinct from the germ line or in facilitating differentiation toward endodermal lineage commitment [32,33]. Both genes, Ddx4 and Dppa3, are aberrantly upregulated in our rybp-deficient ESCs and Ddx4 is expressed throughout cardiac-derived differentiation in $r y b p^{-/-}$CMCs. In our experiments, forced expression of exogenous Rybp partially restored the repressed state of genes that is important for normal germ cell development in the rybp-deficient ESCs. This underlines the function of Rybp in epigenetic regulation at early-stage embryonic development [31] and pinpoints the importance of germ line gene silencing during somatic differentiation.

In summary, we demonstrate, for the first time, that the differentiation capacity of ESCs that lack rybp toward the cardiogenic cell fate is severely impaired. We find that $r y b p$ null ESCs are blocked in cardiac differentiation. Finally, we present evidence that Rybp contributes to the contractility of CMCs during stem cell differentiation.

\section{Acknowledgments}

The authors thank Dr. Joseph Locker for stimulating discussions. They are indebted to Radone Gyugyi for the superb technical assistance rendered.

This work was supported by NKTH-OTKA FP7 “Mobility" HUMAN-MB08C-80205; InduStem, PIAP-GA-2008230675; InduHeart, PEOPLE-IRG-2008-234390; InduVir, PEOPLE-IRG-373 2009-245808; and Plurisys HEALTH2007-B-223485 and Research Center of Excellence 9878/ 2015/FEKUT.

\section{Author Disclosure Statement}

No competing financial interests exist.

\section{References}

1. Davidson EH, JP Rast, P Oliveri, A Ransick, C Calestani, et al. (2002). A genomic regulatory network for development. Science 295:1669-1678.

2. Novershtern N, A Subramanian, LN Lawton, RH Mak, WN Haining, et al. (2011). Densely interconnected transcriptional circuits control cell states in human hematopoiesis. Cell 144:296-309.

3. Odom DT, N Zizlsperger, DB Gordon, GW Bell, NJ Rinaldi, et al. (2004). Control of pancreas and liver gene expression by HNF transcription factors. Science 303:1378-1381.

4. Gao Z, J Zhang, R Bonasio, F Strino, A Sawai, et al. (2012). PCGF homologs, CBX proteins, and RYBP define functionally distinct PRC1 family complexes. Mol Cell 45:344-356.

5. Garcia E, C Marcos-Gutierrez, M del Mar Lorente, JC Moreno and M Vidal. (1999). RYBP, a new repressor protein that interacts with components of the mammalian Polycomb complex, and with the transcription factor YY1. EMBO J 18:3404-3418.

6. Pirity MK, J Locker and N Schreiber-Agus. (2005). Rybp/ DEDAF is required for early postimplantation and for central nervous system development. Mol Cell Biol 25: 7193-7202.

7. Pirity MK, WL Wang, LV Wolf, ER Tamm, N SchreiberAgus, et al. (2007). Rybp, a polycomb complex-associated protein, is required for mouse eye development. BMC Dev Biol 7:39.

8. Nagy A, J Rossant, R Nagy, W Abramow-Newerly and JC Roder. (1993). Derivation of completely cell culture-derived mice from early-passage embryonic stem cells. Proc Natl Acad Sci U S A 90:8424-8428.

9. Magin TM, J McWhir and DW Melton. (1992). A new mouse embryonic stem cell line with good germ line contribution and gene targeting frequency. Nucleic Acids Res 20:3795-3796.

10. Lois C, EJ Hong, S Pease, EJ Brown and D Baltimore. (2002). Germline transmission and tissue-specific expression of transgenes delivered by lentiviral vectors. Science 295:868-872.

11. Dull T, R Zufferey, M Kelly, RJ Mandel, M Nguyen, et al. (1998). A third-generation lentivirus vector with a conditional packaging system. J Virol 72:8463-8471. 
12. Klincumhom N, MK Pirity, S Berzsenyi, O Ujhelly, S Muenthaisong, et al. (2012). Generation of neuronal progenitor cells and neurons from mouse sleeping beauty transposon-generated induced pluripotent stem cells. Cell Reprogram 14:390-397.

13. Rungarunlert $\mathrm{S}, \mathrm{N}$ Klincumhom, I Bock, C Nemes, $\mathrm{M}$ Techakumphu, et al. (2011). Enhanced cardiac differentiation of mouse embryonic stem cells by use of the slowturning, lateral vessel (STLV) bioreactor. Biotechnol Lett 33:1565-1573.

14. Rungarunlert S, N Klincumhom, T Tharasanit, M Techakumphu, MK Pirity, et al. (2013). Slow turning lateral vessel bioreactor improves embryoid body formation and cardiogenic differentiation of mouse embryonic stem cells. Cell Reprogram 15:443-458.

15. Trapnell C, L Pachter and SL Salzberg. (2009). TopHat: discovering splice junctions with RNA-Seq. Bioinformatics 25:1105-1111.

16. Morey L, G Pascual, L Cozzuto, G Roma, A Wutz, et al. (2012). Nonoverlapping functions of the Polycomb group Cbx family of proteins in embryonic stem cells. Cell Stem Cell 10:47-62.

17. Zheng L, O Schickling, ME Peter and MJ Lenardo. (2001). The death effector domain-associated factor plays distinct regulatory roles in the nucleus and cytoplasm. J Biol Chem 276:31945-31952.

18. Stanton SE, JK Blanck, J Locker and N Schreiber-Agus. (2007). Rybp interacts with Hippi and enhances Hippimediated apoptosis. Apoptosis 12:2197-2206.

19. Delgado-Olguin P, Y Huang, X Li, D Christodoulou, CE Seidman, et al. (2012). Epigenetic repression of cardiac progenitor gene expression by Ezh2 is required for postnatal cardiac homeostasis. Nat Genet 44:343-347.

20. Boyer LA, K Plath, J Zeitlinger, T Brambrink, LA Medeiros, et al. (2006). Polycomb complexes repress developmental regulators in murine embryonic stem cells. Nature 441:349-353.

21. Simon JA and RE Kingston. (2009). Mechanisms of polycomb gene silencing: knowns and unknowns. Nat Rev Mol Cell Biol 10:697-708.

22. He A, Q Ma, J Cao, A von Gise, P Zhou, et al. (2012). Polycomb repressive complex 2 regulates normal development of the mouse heart. Circ Res 110:406-415.

23. Takihara Y, D Tomotsune, M Shirai, Y Katoh-Fukui, K Nishii, et al. (1997). Targeted disruption of the mouse homologue of the Drosophila polyhomeotic gene leads to altered anteroposterior patterning and neural crest defects. Development 124:3673-3682.

24. Shirai M, T Osugi, H Koga, Y Kaji, E Takimoto, et al. (2002). The Polycomb-group gene Rae28 sustains Nkx2.5/ Csx expression and is essential for cardiac morphogenesis. J Clin Invest 110:177-184.
25. Gregoire S, R Karra, D Passer, MA Deutsch, M Krane, et al. (2013). Essential and unexpected role of Yin Yang 1 to promote mesodermal cardiac differentiation. Circ Res 112:900-910.

26. Tavares L, E Dimitrova, D Oxley, J Webster, R Poot, et al. (2012). RYBP-PRC1 complexes mediate H2A ubiquitylation at polycomb target sites independently of PRC2 and H3K27me3. Cell 148:664-678.

27. Richly H, L Rocha-Viegas, JD Ribeiro, S Demajo, G Gundem, et al. (2010). Transcriptional activation of polycombrepressed genes by ZRF1. Nature 468:1124-1128.

28. Nishii K, S Morimoto, R Minakami, Y Miyano, K Hashizume, et al. (2008). Targeted disruption of the cardiac troponin $\mathrm{T}$ gene causes sarcomere disassembly and defects in heartbeat within the early mouse embryo. Dev Biol 322: 65-73.

29. Shinke T, J Shite, H Takaoka, K Hata, N Inoue, et al. (2007). Vitamin C restores the contractile response to dobutamine and improves myocardial efficiency in patients with heart failure after anterior myocardial infarction. Am Heart J 154:645.

30. Choi KM, YK Seo, HH Yoon, KY Song, SY Kwon, et al. (2008). Effect of ascorbic acid on bone marrow-derived mesenchymal stem cell proliferation and differentiation. J Biosci Bioeng 105:586-594.

31. Hisada K, C Sanchez, TA Endo, M Endoh, M RomanTrufero, et al. (2012). RYBP represses endogenous retroviruses and preimplantation- and germ line-specific genes in mouse embryonic stem cells. Mol Cell Biol 32:1139_ 1149.

32. Gustafson EA and GM Wessel. (2010). Vasa genes: emerging roles in the germ line and in multipotent cells. Bioessays 32:626-637.

33. Wongtrakoongate P, M Jones, PJ Gokhale and PW Andrews. (2013). STELLA facilitates differentiation of germ cell and endodermal lineages of human embryonic stem cells. PLoS One 8:e56893.

Address correspondence to:
Dr. Melinda Katalin Pirity
Institute of Genetics
Biological Research Centre
Hungarian Academy of Sciences
Szeged H-6726
Hungary

E-mail: pirity.melinda@brc.mta.hu

Received for publication December 8, 2014 Accepted after revision May 22, 2015

Prepublished on Liebert Instant Online June 3, 2015 